COLONIAL INCLUSIVITY: HISTORICAL EDUCATION AND STATE CAPACITY IN POST-COLONIAL STATES

A Dissertation
Presented to
the Faculty of the Graduate School
at the University of Missouri-Columbia
In Partial Fulfillment
of the Requirements for the Degree
Doctor of Philosophy
TIFFANESHA WILLIAMS
br. Jonathan Krieckhaus, Dissertation Supervisor
MAY 2019


(C) Copyright by Tiffanesha Williams 2019

All Rights Reserved 
The undersigned, appointed by the dean of the Graduate School, have examined the dissertation entitled

\section{COLONIAL INCLUSIVITY: HISTORICAL EDUCATION AND STATE CAPACITY IN POST-COLONIAL STATES}

presented by Tiffanesha Williams,

a candidate for the degree of Doctor of Philosophy,

and hereby certify that, in their opinion, it is worthy of acceptance.

Dr Jonathan Krieckhaus

Dr. Sheena Greitens

Dr. Stephen Quackenbush

Dr. Kristin Kopp

Dr. Thomas Pepinsky 


\section{ACKNOWLEDGEMENTS}

I would first like to thank my advisors in the Department of Political Science and the support of my colleagues, who have been instrumental in making this degree possible. Without their support, honesty, and invaluable time offered, I would not be the educator and researcher that I am today.

In particular, I would like to thank Dr. Jonathan Krieckhaus for his commitment to my development, through all the ups and downs that I faced during my tenure in the program. Without his willingness to take a chance on me after a disastrous first year, I would have shied away from finishing the program.

Additionally, I would like to thank the various faculty members who I have taken courses with during the program, as well as each of my dissertation committee members (Dr. Sheena Greitens, Dr. Stephen Quackenbush, Dr. Kristin Kopp, and Dr. Thomas Pepinsky). Each of them contributed to my development as a scholar and the integrity of this document. I hope to honor their diverse contributions in the next iteration of this project.

I would also like to thank the various faculty members who were integral to my decision to attend graduate school, and to continue onto the doctorate. If not for the dedication of Dr. Michael Hawkins to engaging teaching and passion for Southeast Asian history, I would have continued down my path towards law school. If not for the encouragement of Dr. Michael Buehler, who believed in my abilities, I would have decided to end my journey at my Master's.

I would be remiss not to thank the many wonderful individuals outside of my academic program that made my experience at the University of Missouri rich, inspiring, and full of love. Namely, without the support and mentorship of Dr. NaTashua Davis, I 
undoubtedly would not have been retained after my first year. I would like to thank my Association of Black Graduate and Professional Students family, and other friends from across the institution (you know who you are) for your support throughout this process.

Finally, I would like to thank my family, especially my biggest cheerleader, Rose, for partnering with me as I traversed new territories for our bloodline. This first is for the Burks/Williams legacy. 


\section{Table of Contents}

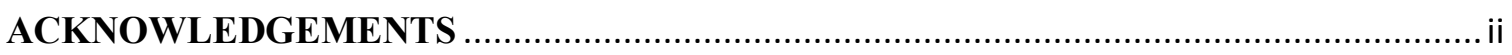

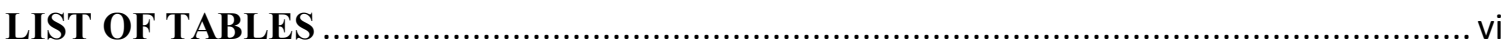

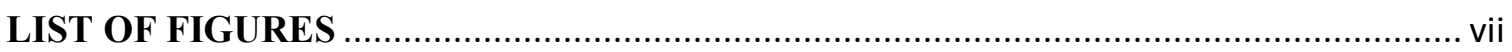

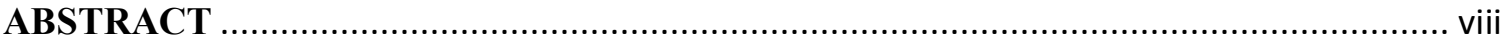

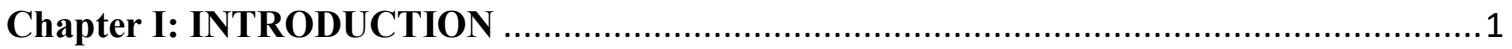

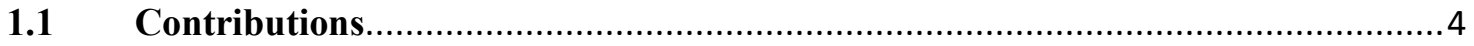

1.2 Colonial Studies in Political Science ........................................................... 7

1.2.1 Situating this Study in the Literature .......................................................... 8

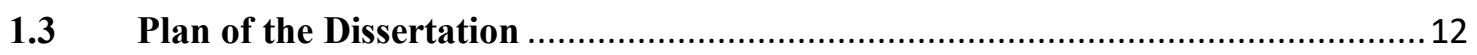

Chapter II: COLONIAL INCLUSIVITY AND STATE CAPACITY ............................. 14

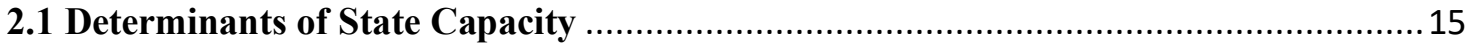

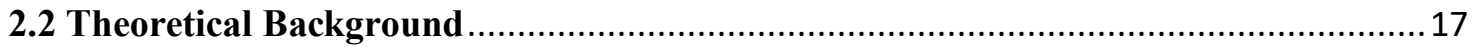

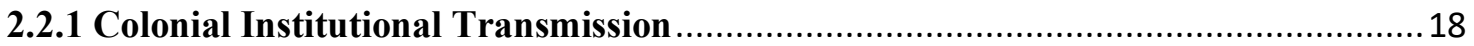

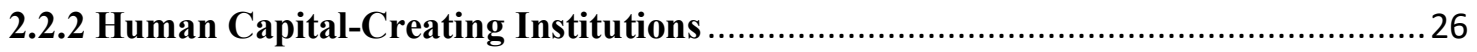

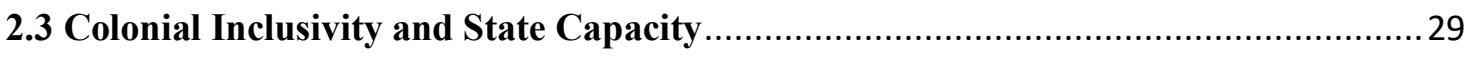

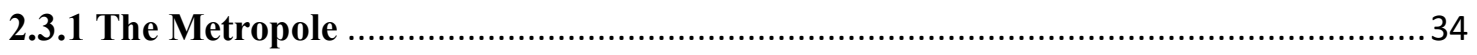

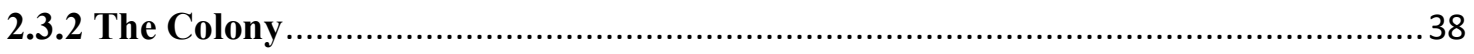

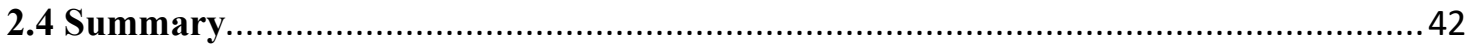

Chapter III: COLONIAL SETTLEMENT AND STATE CAPACITY IN POST-

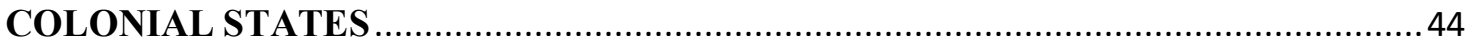

3.1 Level of Settlement and Institutional Quality ..................................................... 47

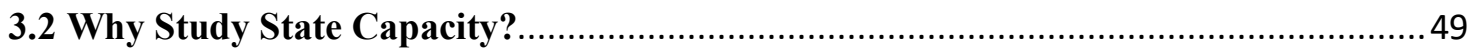

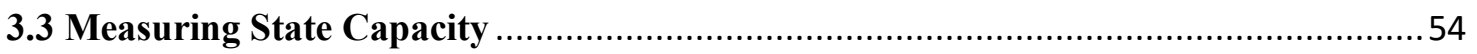

3.4 European Colonial Settlement and State Capacity .............................................. 58

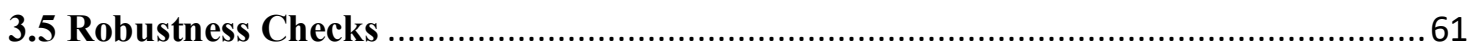

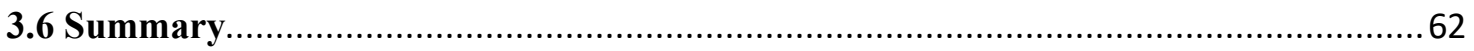

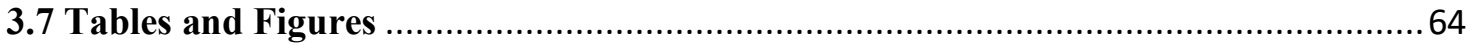

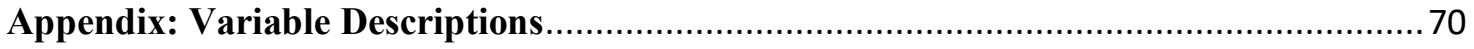

Chapter IV: COLONIAL EDUCATIONAL ATTAINMENT AND CONTEMPORARY

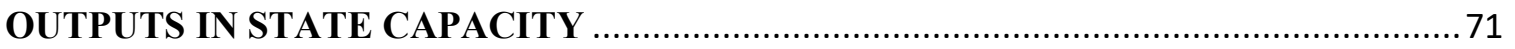

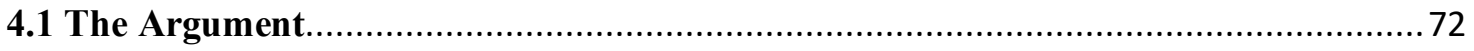




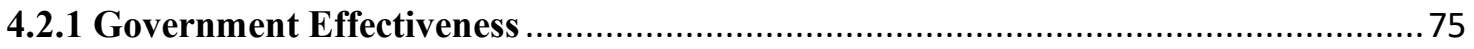

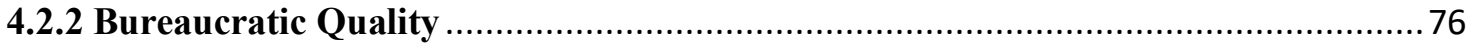

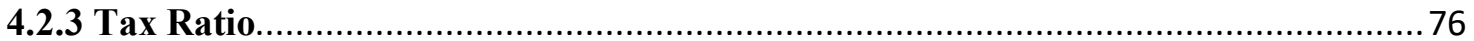

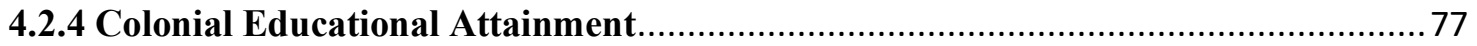

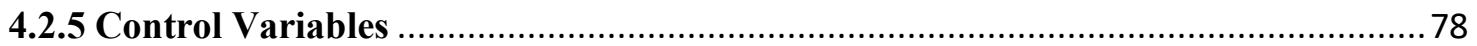

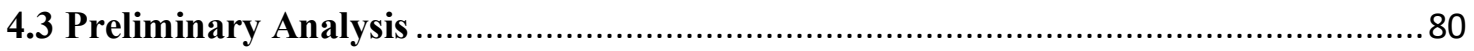

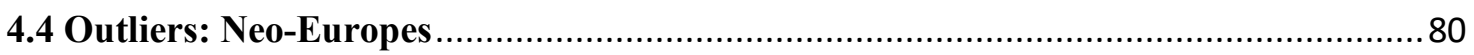

4.5 Does Colonial Education Attainment Merely Reflect Prior State Capacity? ..............81

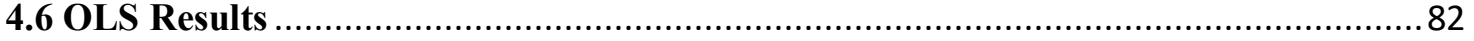

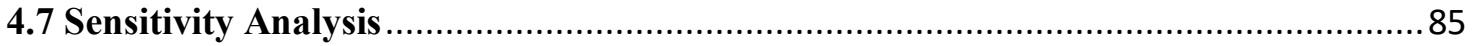

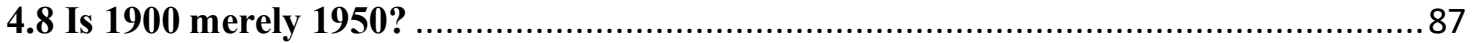

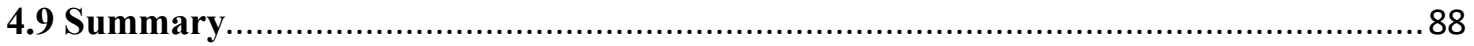

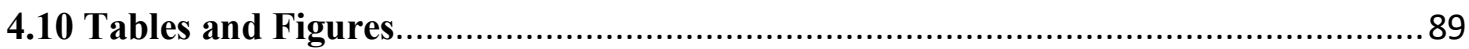

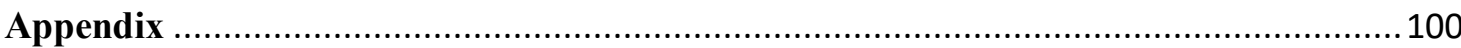

Chapter V: THE EVOLUTION OF EDUCATION, THE BUREAUCRACY, AND

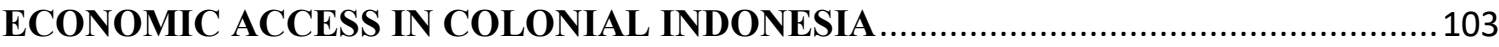

5.1 The Netherlands Economic Climate in the $19^{\text {th }}$ and early $20^{\text {th }}$ Century.................... 108

5.2 The Rise of Classical Constitutional Liberalism in the Netherlands...................... 112

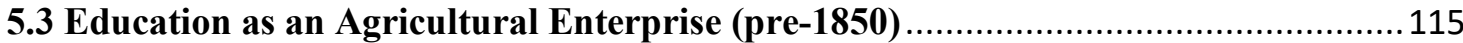

5.4 The Rise of Liberal Education and Access to the Bureaucracy (1850-1900) ............ 118

5.5 The Expansion of Liberalism in the Archipelago (1900-1942) .................................. 121

5.6 Japanese Interruption: A Critical Juncture (1942-1945) ......................................... 124

5.7 Post-Independence: Education and the Status of Weberian Institutions..................126

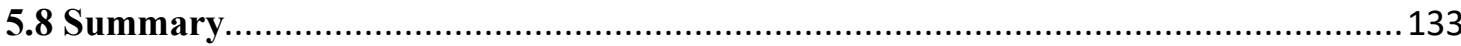

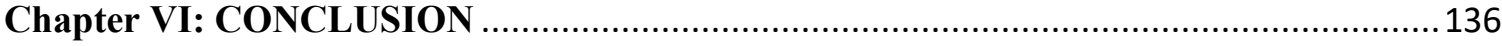

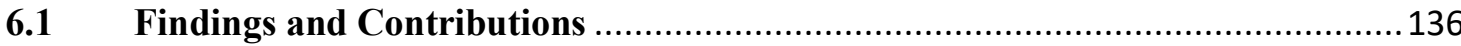

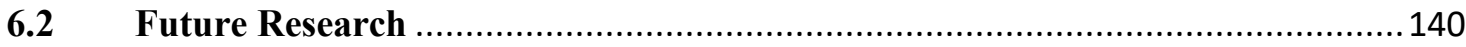

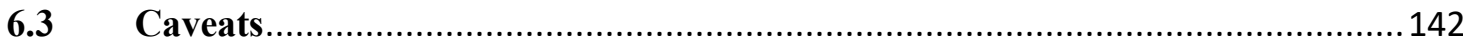

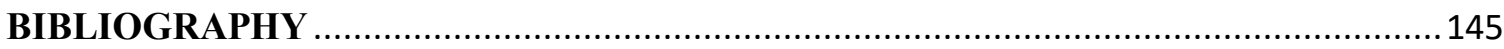

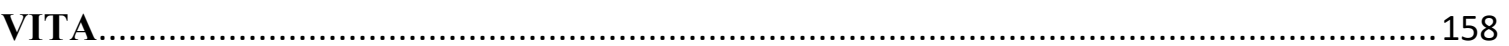




\section{LIST OF TABLES}

Table 3.1: AJR (2001) Average Protection Against Expropriation Risk in 1985-1995.......64

Table 3.2: AJR (2001) Constraint on Executive in 1900...............................65

Table 3.3: Measures of State Capacity in 2010 and Level of European Settlement (1900)...66

Table 3.4: Measures of State Capacity in 2010 and Settler Mortality.....................67

Table 3.5: Measures of State Capacity in 2010 with Huber Weights.........................68

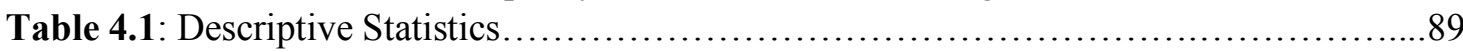

Table 4.2: Correlations.............................................................. 90

Table 4.3: Historical State Capacity and Colonial Education Policy...................... 92

Table 4.4: World Bank Government Effectiveness and Educational attainment in 1900.....93

Table 4.5: World Bank Government Effectiveness and Educational Attainment levels without

Neo-Europes

Table 4.6: ICRG Bureaucratic Quality and Educational Attainment levels without Neo-

Europes......................................................................... 95

Table 4.7: World Bank Tax Ratio and Educational Attainment in 1900 without Neo-

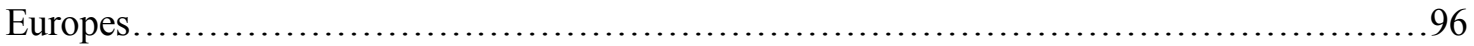

Table 4.8: State Capacity and Educational Attainment with Colony Dummy without NeoEuropes.......................................................................... 97

Table 4.9: World Bank Government Effectiveness and Educational Attainment given

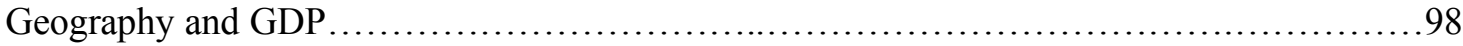

Table 4.10: State Capacity and Educational Attainment with Colony Dummy without NeoEuropes

Table 4.11: ICRG Bureaucratic Quality and Educational Attainment levels with NeoEuropes.

Table 4.12: World Bank Tax Ratio and Educational Attainment in 1900 with Neo-

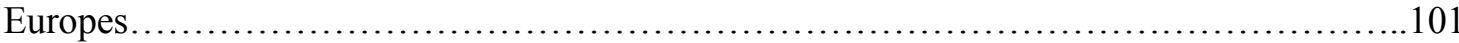

Table 4.13: Colonial education and state capacity................................... 102

Table 5.1: The Dutch Educational Framework in the Netherlands East Indies (pre-1850 to 1942).

Table 5.2: Teachers' Colleges Completion Rates in late $19^{\text {th }}$ Century (Penders 1968, 29). 


\section{LIST OF FIGURES}

Figure 2.1: Institutional Transmission and Economic Development........................18

Figure 2.2: Human Capital and Economic Development.................................27

Figure 2.3: Colonial Inclusivity and State Capacity.................................. 34

Figure 3.1: Level of European Settlement and Government Effectiveness...................69

Figure 3.2: Variable Descriptions.................................................... 70

Figure 4.1: Two-way Scatterplot of Total Years of Schooling (ages 15-64) and World Bank

Government Effectiveness........................................................ 90

Figure 4.2: Two-way Scatterplot of Total Years of Schooling (ages 15-64) and World Bank

Government Effectiveness (w/o U.S., Canada, New Zealand, and Australia).................91

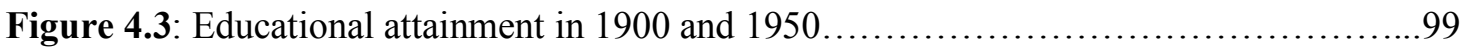

Figure 5.1: The Effect of Colonial Investment in Education on State Capacity...............105

Figure 5.2: The Process of Colonial Inclusivity Development in Indonesia..................106 


\begin{abstract}
The contribution of this dissertation is to show that colonial state building efforts were more successful in the long term when the state invested in education for the colonized population. This argument builds upon recent literature showing that state cooptation of indigenous populations can facilitate state building, but I go further in arguing that colonial policy was not only cooptation, but in some contexts inclusive, leading the population to be vested in and participants in the state. I develop an argument for the influence of the causal mechanism, colonial inclusivity, on contemporary state capacity in post-colonial states. Through a qualitative and quantitative investigation of this mechanism, I find that the investment in and the colonized population's access to quality education during the colonial period reaps positive gains for contemporary state capacity.
\end{abstract}




\section{Chapter I: INTRODUCTION}

This dissertation contributes to a growing literature examining how colonialism has structured the modern world. I specifically examine how colonialism influenced state building and contemporary state capacity. My primary contribution is to extend recent and interesting developments in the colonial literature, which note that outcomes in the periphery arise from the interaction of metropole policies and domestic social structures, and are not merely dictated by colonial powers. Prominent examples of these approaches are Frankema (2013), Lange (2009), Mahoney (2010), Matsuzaki (2019), and Owolabi (2015). These scholars examine how metropole colonial strategies, such as direct and indirect rule, or the extent of co-opting local elites, influenced the success of the colonial state building project.

My dissertation notes that the interaction between metropole policies and domestic structures goes even deeper. Whereas the current literature continues to view these interactions as a form of state control, leading to domestic compliance, I argue that the colonial state-society relationship also includes an element of inclusion, in which local populations are incorporated into the state building project through education and socialization, rather than just cooptation and coercion. Moreover, whereas cooptation helped gain compliance with the colonial state, the increase in educational access and inclusion in the state helped induce endearment ${ }^{1}$ to the colonial state.

Therefore, this dissertation is a story of the transformative power of education for the human capital of a population, and more specifically how that transformation fuels

\footnotetext{
${ }^{1}$ What I mean here is that natives could see their own personal interests come into alignment with the colonial state, and want to perpetuate a model in which their interests are best served.
} 
political outcomes. The importance of education for politics has been theorized by modernization scholars since Lipset (1959). This dissertation investigates an overlooked yet historically important slice of the education and politics nexus, which is how much and in what manner imperial states implemented education policies in the colonies circa 1850-1950. I evaluate theoretically and empirically the effect of colonial education policy (henceforth colonial inclusivity) on contemporary state capacity. The latter phrase has many meanings, but despite huge variations in how the concept has been measured, most policy practitioners and social scientists do argue that some states have a higher capacity to get things done, while others states simply do not have this capacity. Although this relationship between education and politics is certainly not unique to colonialism, understanding the colonial context is important because the colonial enterprise was disruptive of pre-colonial trajectories of human history and, as argued below, continues to shape contemporary politics.

Indonesian colonial history, and in particular the expansion of education during the colonial period, nicely illustrates the central assertion of this dissertation, which is that imperial states can and do intentionally create human capital in indigenous populations in an attempt to build states. From the early part of the $19^{\text {th }}$ century until sovereignty was officially granted in 1949, the Dutch strategy in the Netherlands East Indies $^{2}$ underwent rapid transformation. Most notably, with the transition of control over the archipelago from the Dutch East Indies Company to the Dutch government, this period is marked by intentional shifts in policy related to the provision of education for the native population. Their education policy in the East Indies received a boost by

\footnotetext{
${ }^{2}$ Often used interchangeably with "Dutch East Indies".
} 
increasing the expenditures for education and evolving from using education to maintain a strong agricultural indigenous workforce, to using it as a means of building a cadre of skilled laborers that could help manage the state apparatus. The Dutch Parliament was motivated to shift their approach in the Netherlands East Indies on one hand as an output of rising classical liberalism ${ }^{3}$ in Parliament in the $19^{\text {th }}$ century, and on the other hand as a function of their desire to expand to outer islands rich in resources. As a result, in the middle of the $19^{\text {th }}$ century, the percentage of the total population that was enrolled in school at all levels was abysmal ${ }^{4}$ compared to the rest of the world $(15,000)$, whereas that number ballooned into the millions by their official independence in 1949 .

This evolution in the Dutch colonial policy on education that granted the indigenous population greater access to the educational opportunities necessary for social mobility resulted in the creation of a native corps of bureaucrats (Pangreh Praja), which remained a bureaucracy after independence. First, the use of education as a state building effort would have ramifications for the structure of the bureaucracy after independence, even when accounting for the brief, but meaningful, disruption of the Japanese occupation (1942-1945). Second, even though education bounced back after the Japanese occupation and the bureaucratic structures had some permanence, the Japanese occupation did alter the quality of education and state building. This is distinct from the effect of Japanese colonialism in South Korea (Kohli 1994).

\footnotetext{
${ }^{3}$ In chapter 5, I provide a thorough explanation for the rise of classical liberalism in Europe during this period, and how it effects policy preferences in the Dutch parliament.

${ }^{4}$ According to Furnivall (1943), the primary school enrollment in the Netherlands East Indies was significantly behind its neighbors, Taiwan, Philippines, British Malaya, and in Thailand where the enrollment rates were three times higher than the Netherlands East Indies.
} 
My argument extends the canonical literature on colonialism by incorporating the influence of colonial educational policy on state building success, while at the same time exploring a different outcome - economists' understanding of 'state capacity'. The importance of colonial legacy has been predominantly addressed in the political economy literature and has particularly focused on economic development. To date, the literature has emphasized the importance of varying levels of European settlement for institutional quality in the colonies and the way that this contributed to divergent outcomes in economic development (Acemoglu, Johnson, and Robinson 2001; Banerjee and Iyer 2005; Feyrer and Sacerdote 2009; Sokoloff and Engerman 2000). There is considerable evidence that higher levels of European settlement had a broadly positive effect on economic development in former colonies through the transmission of institutions and codification of property rights. While these studies highlight the importance of colonial settlement for transmitting liberal institutions at the macro-level, the field still lacks an explicit assessment of how state-society relations under colonialism facilitated or hindered institutional transmission and the state capacity of these former colonies after independence.

\subsection{Contributions}

This study makes several contributions. First, it looks beyond economic growth to focus on other outcomes impacted by colonial rule - namely education attainment levels and state institutions. This study follows the many cross-national studies contemplating the influence of colonialism but diverges by focusing on an overlooked dependent variable - state capacity. Moreover, this study tests the relationship between the level of European settlement and contemporary state capacity, which has not been done before in 
the literature. At the same time, the project investigates the development of state capacity in the literature and the link between its theoretical form and operationalization.

The second and main contribution of this study is an exploration of the influence of colonial inclusivity in the realm of education on the quality of the bureaucracy, which in turn affects contemporary state capacity and economic development. This concept, colonial inclusivity, reflects the level at which colonial administrators (located both within the colony and in the sending state) invested in the human capital of the colonized population. At the core of this investigation is an argument that education (the tool) and the development of human capital (the result) are instrumental to state building. This argument for colonial inclusivity extends the framework of Reo Matsuzaki (2019) who argues that the colonial state developed a connection with society via indigenous intermediaries who were agents of the state, who were also deeply connected to the indigenous population via a shared identity and values. According to Matsuzaki, these intermediaries were instrumental to helping the colonial state foster compliance from the population for colonial objectives. My argument takes this logic a step further by adding that education and higher levels of educational attainment helped socialize the indigenous population to the point of becoming invested in the colonial state and state building efforts. Additionally, as the standards for entrance into the public service became more meritocratic, education served as a means of incorporating the indigenous population into the bureaucracy. This was prominently seen in colonial contexts that necessitated more non-Europeans to help fuel the state.

The infusion of more access to western, liberal education towards the end of the $19^{\text {th }}$ century distinguishes colonies that experienced leadership vacuums (e.g. Belgian 
Congo) and those that did not (e.g. Netherlands East Indies). Arguably, in most colonial contexts European leaders used intermediaries or co-opted local leaders to squelch uprisings from within the population and to fortify compliance from the population. This strategy is also seen in the slave colonies of North America and the Caribbean. An important distinction between the colonies wherein co-optation was the dominant strategy and those that used a mix of this strategy and intentional or unintentional empowerment via education, is that post-colonial leaders were better equipped to continue state building projects.

To understand why this variation in strategy exists, I return to my opening statement and reiterate that this theory of colonial inclusivity is the product of the interaction between the metropole and domestic structures. This interaction can be organized into what was going on in the metropole and how that influences the policy implemented in the colony. In the metropole, the shift in general policy in the colonies can be attributed to rise of classical liberalism in Europe's parliaments during the $19^{\text {th }}$ century and the shifting economic interests of the colonizer, but this did not naturally translate into the building of institutions that would have permanence after independence. Rather, the formation of inclusive institutions, such as educational institutions and bureaucracies that provided greater access to the indigenous population, ultimately led to institutional transmission that has endured. Therefore, the interaction between the metropole and the polity contributed to contemporary state capacity in former colonies.

Moreover, these early investments in state building had important long-term consequences. As Mahoney $(2010,204)$ argues, the trajectory of post-colonial institutions was marked by path dependent increasing returns: 
Countries with institutions that are advantageous at one point in time tend to have different but still advantageous institutions at a latter point. Effective institutions beget other effective institutions, ineffective ones foster other ineffective ones.

In the pages that follow, I build on Mahoney (2010), Matsuzaki (2019), and the existing literature by providing an explanation for how this path was created and sustained. I explain this process more fully in my main theoretical chapter, Chapter II, and investigate it quantitatively in Chapter IV.

\subsection{Colonial Studies in Political Science}

The importance of this study for social science is demonstrated by a significant lacuna in the political economy literature of colonialism and economic developmentexisting studies do not adequately explain how and why colonialism influenced postcolonial states. Much of this literature, particularly in the discipline of economics, is driven by the question of whether historical levels of state institutional quality explain contemporary variation in national income levels. As such, most studies utilize two-stage least squares (2SLS) to avoid the endogeneity between wealth and state institutions. A few seminal studies do focus squarely on how colonialism influences states and societies (Kohli 1994; Lange 2003, 2009; Mahoney 2010; Matsuzaki 2019; Owolabi 2015, 2019). These studies, however, examine broader patterns of state-society relations. Rarely if ever do these studies give explicit attention to concepts such as institutional quality. There now exists a large literature on the colonial politics of state capacity, qualitatively understood, but there is little to no literature on how colonialism influenced contemporary state capacity as understood and measured by economists and public policy scholars. In short, there now exist two general literatures, one focusing on colonialism merely as an instrument in $2 \mathrm{SLS}$, and the other more generally interested in colonialism 
but without giving much explicit attention to property rights, quantitative measures of "state capacity", and other related research. This dissertation advances a new research agenda by exploring the lacuna between these two prominent literatures.

\subsubsection{Situating this Study in the Literature}

I now turn to a brief exploration of the two literatures noted above, focusing on the arguments most salient to this study. I then move into a close examination of the study that has been at the center of the political economy investigation of colonial legacy (Acemoglu, Johnson, and Robinson 2001).

Contemporary colonial studies received much of its impetus from a number of studies arguing that European colonialism had a positive effect on the economic development of former colonies (Acemoglu, Johnson, and Robinson 2001; Easterly and Levine 2003; Englebert 2000; Engerman and Sokoloff 2002; Fails and Krieckhaus 2010; Kohli 1994; Lange 2003 and 2009; Mahoney 2010; Lange, Mahoney, and Vom Hau 2006). Their explanations for why there are variant outcomes for how European colonialism affects former colonies can be organized into four main categories : 1) institutional incongruence between pre-colonial and post-colonial institutions can explain the divergence in economic growth and to a certain extent state capacity (Englebert 2002); 2) colonial institutional arrangements were inherently adverse to long term growth particularly for colonies with high inequality (Engerman and Sokoloff 2002); 3) the building of bureaucratic structures and the embeddedness of the colonial apparatus fostered a "state-society synergy" leading to effective institutions for long term development (Lange 2003); and 4) variation in general colonial strategies by different 
colonial regimes led to divergent outcomes in economic growth (Lange 2009). This growing body of work on the colonial origins of contemporary incomes is rich with datasets and causal insights but does not investigate the intervening process. The question remains: What exactly were these state institutions and how specifically was a highcapacity state created and maintained?

A second body of literature on colonialism moves us closer to an explicit examination of colonial strategy and its relevance for post-colonial state building (Englehart 2005; Fukuyama 2004; Hameiri 2009; Lange 2003; Matsuzaki 2019; Migdal 1988 and 2009; Wantchekon; Klasnja, and Novta 2013; Xu 2017). Each of the aforementioned scholars implicitly theorizes about the effect of colonialism on one aspect of state capacity, typically institutional capacity. Two contemporary additions to the literature help situate this study. The first is Matsuzaki's (2019) argument for the importance of mediational institutions for colonial state building. Specifically, Matsuzaki argues that colonial powers were able to impose state building onto colonized populations by coopting intermediaries, leaders and elites from within the colonized population, to maintain order and gain compliance with colonial policies. These intermediaries were able to leverage their various linkages with the population, for example as heads of religious organizations, in order to solicit, and in some instances, coerce compliance. This analysis provides some clarity for the intervening process that would make colonial institutions ripe for long-term durability.

The second relevant study is Owolabi (2015, 2019 forthcoming) who argues that forced settlement colonies and colonial occupation colonies produced different outcomes for economic and human development, along with political legacies in former colonies. 
Forced settlement colonies, like Mauritius, Guyana, and Trinidad, occurred during the "Age of Discovery in the New World and had predominantly migrant populations of African and Asian descent, brought there for agricultural production. On the other hand, colonial occupation colonies, like Nigeria, Sierra Leone, and Uganda, were established during the second wave of colonialism in the late $19^{\text {th }}$ century and had populations largely comprised of indigenous groups. Owolabi argues that the difference in population structures and having a "blank slate' ${ }^{5}$ led to the implementation of inclusive, legal administrative frameworks in forced settlement colonies, which was not always the case in colonial occupation colonies with stronger pre-existing structures. After independence, the economic and human development in forced settlement colonies, like Barbados, was not only better than their colonial occupation counterparts, but also developed countries like the United States, Australia, and United Kingdom. Like Lange (2009) and Mahoney (2010), Owolabi provides more clarity for why certain colonial strategies were selected and how certain colonial contexts led to different outcomes.

However, even these contemporary additions do not formulate an explicit theory of colonialism's relation to post-colonial state capacity. Moreover, all except for Matsuzaki (2019) focus primarily on the effect of European settlement on post-colonial state building. I argue, by contrast, that understanding colonial practice is profoundly important, because state capacity is at the heart of long-run modernization of the state, strength of the economy, and economic distribution (Fukuyama 2004; Grindle 1996; Hendrix 2010; Laking 2010; Migdal 1988). Additionally, studying state capacity is

\footnotetext{
${ }^{5}$ Scholars like Owolabi argue that colonial projects that occurred in territories with limited or no central government, operated on a blank slate and were able to implement state building and extraction efforts more freely.
} 
important for the living conditions of populations across the globe, because it provides us with the tools for improving these conditions.

The central purpose of this dissertation is to join Matsuzaki (2019) in providing more context to the intervening process in colonial studies, in which "institutions" are said to exist in colonial territories and subsequently persist among post-colonial populations. As an example of how the existing literature is overly top-down, ignoring the intervening processes, consider Acemoglu, Johnson, and Robinson's (2001) prominent statement that extraction or violent exploitation of resources in colonies, and the erection of absolutist governments, adversely affected post-colonial institutional quality. The structure of colonial governments in their view was predicated on the level of settlement, with settler colonies being modeled after the home country, leading to good institutions after independence (2001, 1574). Alternatively, in non-settler colonies there was high economic motivation, which led to the erection of predatory institutions for extraction purposes $(2001,1575)$. Overall, the internal logic of Acemoglu, Johnson, and Robinson's argument is that extractive and predatory institutions persisted after independence due to: 1) the costliness of setting up institutions that respect property rights; 2) the size of the selectorate or the ruling elite who had an incentive to maintain the status quo; and 3) the willingness of agents of the state to invest in property rights institutions when they have more to lose.

What is missing from their analysis is the very real presence and agency of the colonized population, and how European settler efforts affected the context and condition of their agency. This means that the literature has largely depicted colonized populations as passive recipients of colonial institutions. This assumes that they were equipped and 
inclined to run with the institutions created by European settlers, but there is no explanation for how or why this might have happened. In essence, existing explanations for colonial institutional transmission do not provide much clarity on how this process occurred, with the colonized population as part of the analyses, and what incentivized or better yet socialized the colonized population, particularly post-independence leaders, to adopt these institutions. This dissertation is an attempt to address the transmission process, exploring the reasons for variations in colonial strategy and how these variations in led to varying outputs for human capital, thus can explaining divergent outcomes in contemporary state capacity.

\subsection{Plan of the Dissertation}

The primary goal of this dissertation is to assess the influence of colonial education policies on contemporary levels of state capacity. Chapter II explains in more depth the broader theoretical contribution of this study—how colonial inclusivity shapes state building in former colonies and ultimately influences contemporary state capacity. The chapter articulates the logic of the theory of colonial inclusivity and also provides some background context on how shifts in the metropole influence how policies were implemented in the colony.

In Chapter III, I explore in greater depth the definition and operationalization of state capacity by empirically testing the relationship between the existing indicator for colonialism in the literature-levels of European settlement — and prominent indicators of state capacity across the political economy literature. The primary focus of the existing literature is on the influence of colonialism on economic development, and it finds, 
broadly, that the colonies with a higher percentage of European settlers experienced higher economic growth. My work complements this literature by moving beyond colonialism as an "instrument" that matters for growth to take seriously the causal process underneath.

In the next empirical chapter, Chapter IV, I introduce a new measure of colonial policy - the level of educational attainment - and assess its significance for the prominent indicators of state capacity examined in Chapter III. I test the theory of colonial inclusivity as proxied by the level of educational attainment, while also accounting for existing explanations of post-colonial economic development, such as the level of European settlement, economic growth, geographic location, and pre-colonial institutions. I find that higher levels of educational attainment at the turn of the $20^{\text {th }}$ century offers a more robust explanation for higher levels of contemporary state capacity than the alternatives.

Chapter V is a case study exploring how the causal mechanism-colonial inclusivity - contributes to colonial state building efforts that increase long-term state capacity. Specifically, I trace the development of education policies towards the indigenous population and the inclusion of the indigenous population in the colonial bureaucracy of the Netherlands East Indies (Indonesia). I demonstrate the covariation of educational policies and state building and provide evidence that this covariation was intentional. Finally, I conclude this project with a synthesis of the themes explored and results of each chapter, in Chapter VI. 


\section{Chapter II: COLONIAL INCLUSIVITY AND STATE CAPACITY}

"[Institutions] evolve incrementally, connecting the past with the present and the future; history in consequence is largely a story of institutional evolution in which the historical performance of economies can only be understood as a part of a sequential story." Douglass C. North (1991)

In this chapter, I aim to move the scholarship on colonial legacy forward with an examination of colonial inclusivity and state capacity. Here, I focus on one historical set of policies - education - and examine its impact on bureaucratic institutions that became part of the fabric of state building over time. This process of linking historical education policies and human capital accruement, most notably during the colonial era, is offered as an explanation for contemporary levels of state capacity achieved.

Moreover, this study examines the influence of varying levels of educational proliferation across the whole of the colonial world to make inferences about its effect on state building. Much of this analysis focuses on the early part of the $19^{\text {th }}$ century through to modern times, when liberalism emerged in Europe. The theory introduced here does not account for pre-colonial conditions, nor provide a remedy for the fact that this analysis is still deeply rooted in the effect of European colonialism on the colonized, and not vice versa. Where this assessment diverges from the existing scholarship is in its examination of how decisions directly relevant for the human development of the colonized affected state building and their governance options post-independence.

Here, I focus on education rather than any other policy, for a few reasons: 1) greater educational access serves as a means to connect the colonial state with the 
society; 2) the use of education as a socialization tool aids in legitimizing the colonial state and moving a critical mass of the population from compliance to endearment; and 3) it equips the population to participate in the state as civil servants. These three functions have several implications for state building before and after independence. First, socialization and professionalization through education empowers the population and equips it for self-rule after independence. Second, in contexts where colonial education policies led to higher educational attainment levels amongst the colonized population and where this was coupled with access to civil service positions, institutional transmission was more apt to occur. Moreover, state building in the long term was more successful in such colonies than in colonies in which these processes did not occur.

In the coming pages, I first briefly address the literature on the determinants of contemporary state capacity to set the foundation for how this study fits into the canon, aiming to explain what factors contribute to state capacity. I then provide further theoretical background for the literature that precedes this study, to lay the foundation for why this study matters. After establishing where this study fits, I explain in greater detail how this investigation of colonial inclusivity will be incorporated in the rest of this study.

\subsection{Determinants of State Capacity}

At the core of this study is the goal of moving forward the discipline's understanding of the determinants of state capacity. Thus far, much of the literature on the determinants of state capacity has explored the post-colonial African context. From this discourse, three explanations for the determinants of state capacity have been provided. The first is rooted in the scholarship on civic culture and social trust as a 
precondition for institutional quality (Almond and Verba 1963; 1980; Coleman 1990;

Fukuyama 2005; Putnam 1994), which lends itself to the social capital economic theory (Coleman 1990; Keefer and Knack 1997; La Porta et al. 1999; Widner and Mundt 1998). The social capital economic theory suggests that African institutional stagnation can be explained by low levels of civic culture and economic development. An extension of this line of reasoning is that vertical patron-client relations prevented the political participation and equality necessary for high levels of institutional quality (Dia 1996; Seragddin and Taboroff 1994).

A second explanation for the determinants of state capacity relates to ethnic heterogeneity. Borrowing from Olsen's $(1965 ; 1982)$ theory of collective action, scholars argue that ethno-linguistic fractionalization in many African states makes it difficult for accountability inducing collective action, contributing to weak institutions and the adoption of subpar policies. Finally, a third—and the most relevant explanation for this study — emphasizes the inheritance of artificial states as the result of the Berlin Conference of 1884-85. This inheritance of states that were cobbled together after independence led to neo-patrimonial strategies that comprised the redistribution of resources for the sake of power maximization at the expense of the state (Bayart 1993; Boone 1994; Bratton and van de Walle 1994: Clapham 1982; Englebert 2000a; Jackson and Rosberg 1982; Medard 1982; Sandbrook and Barker1985; Sandbrook 1986; Lewis 1996). ${ }^{6}$

\footnotetext{
${ }^{6}$ I recognize that this is a truncated explication of the state capacity literature. I explore in greater depth the literature on state capacity in Chapter 3. However, it is important to mention that less is known about what determines state capacity than is known about how state capacity affects economic outcomes.
} 
While these assessments of the determinants of state capacity in Africa are helpful, the influence of colonial strategies on governance in post-colonial Africa is not as pronounced as it could be. In studies where the influence of colonialism is addressed, it is usually briefly mentioned in the text or in a footnote. Yet, much of the contemporary political, economic, and social issues in many post-colonial countries, including African countries, can and have been traced back to the colonial period. Momentarily, I will explore some of the literature that supports this claim. In the next chapter, I return to exploring the determinants of state capacity in the context of colonial legacy, while more carefully treating the supporting literature.

\subsection{Theoretical Background}

Much of the political science literature on the significance of colonial legacy for current sociopolitical trends is situated within political economy. Exploring the political economy of colonialism is an exercise in what created the divergence between the legacies of some colonies relative to others. There is little explicit scholarship on the influence of colonialism on state building and contemporary capacity, although there are some scholars explored here who implicitly theorize about colonial legacy and state capacity. Thus, I explore the canon of scholarship trying to make sense of colonial legacy and economic development, because there is evidence to suggest that the same factors that influence economic growth also influence good governance (Careaga and Weingast 2003; Knack and Keefer 1995; Mauro 1995; North 1991; Rodrik, Subramanian, and Trebbi 2004). This exploration also provides a window into the many preconditions that ultimately affects the varying levels of colonial inclusivity. 
The first set of scholars I explore are seated within the tradition of debating whether "institutions matter" and whether institutional transmission is most relevant for post-colonial economic outcomes. The second set of scholars I explore point to the importance of human capital-creating institutions for long term economic development. These two scholarship traditions are the basis for the argument put forth here. Also, the highlighted gaps in the literature serve as evidence of the cruciality of this study for moving both discourses forward. This is to say that it is not enough to understand how colonial institutional choices affected the economic conditions of former colonies, but it is essential that we understand how this ultimately affects the governments that set the parameters for post-colonial economies.

\subsubsection{Colonial Institutional Transmission}

The most relevant political economy literature for this study assesses colonial legacy with an emphasis on the importance of colonial institutional transmission for economic development. To be clear, for the scholars explored here colonial legacy is the product of the institutions that colonizers left in their various territories. The state of the literature can be graphically depicted as the following figure:

Figure 2.1: Institutional Transmission and Economic Development
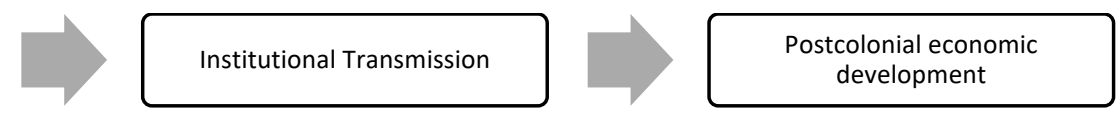

Now, it is not a new argument that institutions erected during the colonial era continue to be relevant well after independence, even when it was not immediately evident in its wake. However, studies of the staying power of colonial institutions have only emerged 
in the last thirty years, and they have predominately focused on the lasting effects of colonial institutions on economic growth.

One of the earliest assessments of its kind was Kohli (1994) who argued that Japanese colonialism, although brutal, imported institutions from Japan that helped shape South Korea into its high growth path of development. This study is important, because Kohli (1994) links the transmission of Japanese institutions to Korean leaders prior to independence to post-colonial economic growth in South Korea. This study occurred at the height of the new institutionalism paradigm that argues that institutions influence human behavior through norms, rules, and other constructs.

This argument is picked up by Evans and Rauch (1999) who argue that the type of institutions being transmitted are important for economic development, connecting the adoption of a meritocratic (i.e. recruitment based on education and examination) Weberian state with higher levels of economic growth. Granted, Evans and Rauch (1999) do not explicitly examine colonial legacy, but their argument, coupled with Kohli's, suggests that the form that institutions take matters - preference given to Weberian institutions in the former - and that their transmission either through colonialism or globalization continues to have contemporary relevance.

Returning to the relationship between the transmission of colonial institutions and economic growth, Englebert (2000) refines Kohli's analysis by highlighting the importance of a congruence between pre-colonial and colonial institutions for effective institutional transmission. In the context of Africa, Englebert argues that many African states suffer from the fact that their formal institutions implemented during the colonial era are not congruent with their informal institutions and norms. This incongruence 
became worse after independence, as the disconnect between the institutions inherited and indigenous informal institutions imploded. Englebert's analysis seems to suggest that some type of "glue" or means of socializing the population is necessary to connect the formal and informal institutions. Arguably, this glue is education, which Fukuyama (2013) and Evans and Rauch (1999) suggest is necessary for indoctrinating a population with norms or reprogramming a population for a new set of norms.

Although much of the early scholarship within this discourse focused on the institutional conditions that could explain economic growth, ${ }^{7}$ in the early part of the $21^{\text {st }}$ century scholars began to focus on the local environmental conditions that influenced colonial legacy. ${ }^{8}$ Most notably, Engerman and Sokoloff (2000) argue that factor endowments (i.e. soils, climates, and the size or density of the native population) predisposed colonies to certain development paths by influencing inequality in wealth, human capital, and political power. These factor endowments influenced the level of settlement ${ }^{9}$ by: 1) inhibiting the number of settlers in some climates while encouraging it in others; 2) encouraging certain colonial strategies over others due to population size and the density of their institutions; and 3) being home to soils that were conducive to certain crops relative to others. These differences in factor endowments can explain why certain colonies that were viewed as places of success during the colonial period, fell behind economically after independence. This meant that being part of the British empire was

\footnotetext{
${ }^{7} \mathrm{I}$ explore the political economy scholarship on the influence of colonialism in various aspects on economic growth, because this literature lends itself to any substantive investigation of colonial legacy and contemporary governance.

${ }^{8}$ Again, the literature thus far assumes that colonial legacy is the institutions that colonizers left. The literature explored in this section provides an alternative explanation-environmental factors informs and constrains colonial policy-for the assumption that institutional transmission determined colonial legacy. ${ }^{9}$ The literature after Acemoglu, Johnson, and Robinson (2001) begins to connect the level of settlement with the type and quality of institutions transmitted to the colonized population during the colonial period and after independence.
} 
not a guarantee of growth (Greene 1988; Kupperman 1995), even though there is scholarship that suggests that it was. In fact, there are those who argue that Myanmar inherited weak institutions from the British, and that these institutions were more militaristic rather than Weberian (Englehart 2005). Moreover, great inequality in the distribution of wealth and human capital in colonies (i.e. mostly black and slave labor colonies like the Caribbean islands) meant poor economic performance after independence. In colonies where there was a more equitable distribution of wealth and higher levels of education, such as the United States and Canada, there was opportunity for the innovation necessary for high levels of economic growth to transpire.

Easterly and Levine (2003) modify this factor endowment explanation by arguing that factor endowments do not have a direct effect on economic development, but instead affect development through their influence on institutions. This moves the literature back to an institutional transmission explanation of colonialism's effect on economic development. For Easterly and Levine (2003), temperate, ecological influences on diseases, and environments are the factor endowments that mattered most for institutions and that were conducive to certain crops. This can be simplified to tropics, germs, and crops. First, Easterly and Levine argue that European settlement was much higher in climates that were more temperate. Europeans were also more likely to stay and govern directly in such cases. This intersected with germs that the European settlers were not acclimated to, which dictated whether the European settlers were forced to implement extractive institutions or were able to settle and implement Weberian institutions. Thus, the institutional options of the settlers responded to the environment, and the economy responded to the institutions implemented. In fact, there are those that argued that "good" 
institutions were mainly a product of non-tropical climates (Hall and Jones 1999).

Second, climate prescribed what crops were able to be grown and exploited (Bloom and Sachs 1998; Landes 1998; Sachs 2001), which contributed to different colonial strategies - institutions - that structured how colonial powers exploited the territory, its people, and its resources. In settler colonies where more Weberian institutions were implemented, it made adopting better productivity techniques and technologies easier and more likely. Some would argue that germs and crops directly affected the technological developments of a society in the long run (Diamond 1997). Interestingly, Easterly and Levine (2003) intuit that "economic policies and institutions reflect current knowledge and political forces. Thus, changes in either knowledge about which policies and institutions are best for development or changes in political incentives will produce rapid changes in institutions and economic policies $(2003,4)$." They conclude that history does not matter, and adverse historical legacies can be reversed. Yet, the historical record does not seem to suggest that Easterly and Levine (2003) are correct in assuming that these adverse trajectories are easy to reverse if at all (Callahan 2009; De Juan and Pierskalla 2017; Frankema 2013; Pepinsky 2016; Pierson 2000; Wantchekon, Klasnja, and Novta 2013; Xu 2017).

Breaking from this emphasis on environmental conditions and how they affected institutional transmission, Lange (2003) argues that a state-society synergy is necessary for the effective transmission of European institutions. Lange argues that the establishment of the bureaucratic state under the French and British in Mauritius was effective because it was accompanied by a society with deep associational ties. This harkens back to scholars like Putnam (1993) who argue for the importance of social 
capital and trust for state building. The marriage between coherence within society and embeddedness of the relationship between the state and society contributes to the staying power of Weberian institutions transmitted during the colonial era. Mauritius is unique in the context of post-colonial Africa, because a development in the 1930s created a synergy between state-society critical for state building, which did not occur in other colonial African contexts. To this point, Lange argues that a "prolonged period of labor riots beginning in the late 1930s and the more interventionist policy of the British government after World War II combined to initiate a "critical-juncture period" that increased relations between state and societal actors $(2003,397) . "$ This state-society synergy contributed to broad-based development and the strengthening of state institutions and societal associations that mattered after independence. There was such a synergy between the state and society prior to independence that $93 \%$ of state positions were held by Mauritians. The question then becomes, how did this come to be?

What is missing from this story and many of those explored thus far is the influence of education on whether colonized bodies rejected the new parameters being imposed on them, or ingrafted them into their sociopolitical structures. Descriptive statistics suggest that the level of educational attainment in Mauritius was comparable to that of Hong Kong, which may explain the efficacy of its bureaucracy during the colonial period and after independence. Arguably, this institutional efficacy had significant positive economic ramifications.

Relatedly, Banerjee and Iyer (2005) add that land revenue institutions were particularly important for the differences in economic outcomes. In context where cultivators rather than landlords were empowered with property rights, there were higher 
agricultural investments and productivity post-independence. For areas where landlords were institutionally extended property rights, even where land reforms were enacted, the class-based antagonism between landlord versus non-landlord created ongoing conflicts and squelched collective action $(2005,1191)$. I add that these dynamics noted by Banerjee and Iyer (2005) in terms of property rights institutions and the differences produced by those who were empowered, worked in tandem with empowerment via education.

As an extension of this idea that colonial institutions matter, Lange, Mahoney, and vom Hau (2006) return to an exploration of whether colonial identity, in and of itself, matters. They argue that the differences in the economic models of Britain and Spain had large consequences for their preferred areas of settlement, the level of colonial institutional building — "the extent to which a colonizing power installs economic, political, and sociocultural institutions in a colonized territory" — and the subsequent development legacies $(2006,1414)$. They also refute the evidence related to factor endowments, by arguing that similar factor endowments produced different levels of institutional establishment by the Spanish and British. Instead, a better predictor of colonial strategy was pre-colonial levels of development, which positively influences the level of Spanish colonialism, but negatively affects the level of British colonialism. This emphasis on the level of colonialism is refuted by Sacerdote and Feyrer (2009) who argue that the timing and length of time that colonialism occurred rather than the type of settlement matters. Specifically, early during the colonial period the choice of what territories to subdue relative to others was in part dictated by windspeeds (i.e. this was before the invention of the steam engine). They find that the timing of colonization 
matters for contemporary economic growth, and colonies that were colonized after 1700 . Colonies that were colonized after the 1700 s experienced a more liberal and innovative colonialism, relative to colonization that happened prior to this ideological shift in Europe (i.e. Spanish colonialism).

Lange, Mahoney, and vom Hau (2006) and Sacerdote and Feyrer (2009) help us understand why certain colonies were colonized, by whom, and to a certain extent when. I add that the preconditions explored here that affected the level of colonialism and timing naturally had an impact on the extent that the colonizers were willing to invest in the development of the population. Notably, colonialism ended in most of Latin America by the early part of the $19^{\text {th }}$ century, with the last independence movement occurring in Uruguay in 1828 (Sacerdote and Feyrer 2009). ${ }^{10}$ This is significant, because Europe began to liberalize at the beginning of the $19^{\text {th }}$ century. This classic liberalism emphasized the importance of protecting the self against encroachment from the state, including the extension of property rights and civil liberties. A result of the expansion of classic liberal thinking was a shift in policymaking in Europe and a corresponding shift in their perception of their responsibility to colonial territories. Prior to the $19^{\text {th }}$ century, Europe had already begun to proliferate numerous educational institutions, and this finally began to surface in many of its colonies a little later in the century. Thus, I recognize that the timing of colonialism matters for the extent of European investment in the populations they subdued. In this regard, colonial inclusivity may be a function of both timing and the related ideological shifts in Europe. I return to the importance of

\footnotetext{
${ }^{10}$ Cuba was the last Spanish colony to receive independence from Spain in 1899, nearly 7 decades after the rest of Latin America.
} 
ideological developments in Europe, in the next section presenting the crux of my argument and state capacity.

The argument for the importance of timing over colonial identity, which influenced strategy, is supported by Fails and Krieckhaus (2010) who argue that the influential story presented by Acemoglu, Johnson, and Robinson (2001) loses much of its strength when the neo-Europes are removed from their analysis. This is to say that even though the British were exceptional at restructuring the societies of The United States, Canada, Australia, and New Zealand, this did not translate the same way into its other colonies. Here, the timing and even the density of the population ${ }^{11}$ intersect to mute some of the positive effects attributed to British colonialism, in the context of economic growth. They conclude their study with the insight that human capital is potentially a more viable intervening process for how institutions affect economic development (2010, 507). This assessment provides a natural segue in to the literature that investigates the missing link in the story on colonial legacy I explore here.

\subsubsection{Human Capital-Creating Institutions}

The first step towards understanding how colonial inclusivity matters for state capacity is provided by Glaeser et al (2004) who argue that the European share of the population matters for the transmission of human capital and human capital creating institutions. This logic regarding the level of European settlement is found in the writings of Easterly and Levine (2012) and Acemoglu, Johnson, and Robinson (2001). Glaeser et al. (2004) argue that human capital creating institutions have implications for economic

\footnotetext{
${ }^{11}$ All the neo-Europes are characterized by their predominately European settlement, as the result of large-scale genocide and uprooting indigenous populations. These include the United States, New Zealand, Australia, and Canada.
} 
development over time. This divergence from the institutional transmission paradigm is graphically depicted as:

Figure 2.2: Human Capital and Economic Development

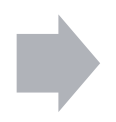

Glaeser et al. (2004) stop short of connecting these human capital creating institutions with state building and state capacity. I move the scholarship forward by adding that these human capital creating institutions were important for other institutions and state building, which in turn influenced economic development. In particular, the quantity and quality of human capital creating institutions implemented during the colonial era maintain their significance in former colonies.

This idea of connecting mass education with governance has some origin in Ulsaner and Rothstein (2014) who link mass education in 1870 to corruption levels in 2010 for 78 countries; finding a positive relationship between universal education and the control of corruption. This is one of the first known times in the literature where the influence of educational attainment levels is assessed for any aspect of governance. Ulsaner and Rothstein (2014) argue that more equitable education policies empower citizens to oppose corruption. Moreover, the need for higher state capacity was a motivation for introducing universal education.

The study that provides the most justification for this extension of the literature is Frankema's (2013) examination of the influence of colonial education on post-colonial governance. In this qualitative assessment, Frankema (2013) compares the colonial education practices in the Belgian Congo and Indonesia, to investigate how the variation 
in colonial education development influences a government's capability for political and macro-economic stability. In particular, Frankema emphasizes the importance of education for the development of indigenous nationalist leadership. For the Belgian Congo, he argues that the expansion of primary education to a broader swath of the population, without greater access to higher education and civil service positions contributed to nationalist leaders without the necessary skills to implement postindependence policies that promoted economic stability. Conversely, Frankema argues that even though Indonesia did not expand educational access as broadly as the Belgian Congo, the population including nationalist leaders had avenues to higher education and the civil service. After independence, nationalist leaders were more skilled, and in the long-term, were able to implement policies that created more economic stability than their counterparts in the Congo.

Relatedly, Owolabi (2015, 2019 forthcoming) argued that forced settlement colonies and colonial occupation colonies produced different outcomes for economic and human development, along with political legacies in former colonies. Owolabi argues that the difference in population structures led to the implementation of inclusive, legal administrative frameworks in forced settlement colonies, which was not always the case in colonial occupation colonies with stronger pre-existing structures. After independence, the human development in forced settlement colonies, like Barbados, were better than colonial occupation colonies.

The major difference between these studies and this study is that I theorize and empirically assess the consequences of colonial mass education policies for state building. I also connect the emergence of human capital creating education policies in the 
colonies with the appearance and evolution of classical liberalism in Europe and the metropole's economic interest.

\subsection{Colonial Inclusivity and State Capacity}

Two assumptions are at the foundation of this investigation of colonial inclusivity and state capacity. The first is that the formation of the bureaucratic state was a purposive endeavor. This is supported by Rueschemeyer and Evans (1985) who argued that the construction and development of the bureaucratic state does not indeed occur on a whim, by a few leaders at independence, but rather is the culmination of state building practices prior to and after independence. In order to holistically understand what causes a state to be effective, one must delve into the past and isolate the essential historical events that established their trajectories for state building (Gryzmala-Busse 2011; Pierson 2000).

The second observation is that state building is comprised of developing state institutions through the professionalization of the bureaucracy, in tandem with developing a civil society that reinforces the state by complying with its objectives (Matsuzaki 2019; Migdal et al. 1994). The importance of civil society for the development of the state, in the Weberian sense, means that state building cannot be divorced from a dual building of society's capacity. When state building exists in a context where civil society is weak, the state is likely to regress into monarchical or dictatorial forms of governance. Thus, this observation implies that our assessments of state building must take into consideration the development of both the state and society. Divorcing one from the other leads to causal explanations that are inherently lacking. 
Given the above observation, this concept of inclusivity is two-fold. One aspect of the concept captures the extent to which the colonized population were given access to education, which serves as a mechanism for strengthening civil society. The second aspect is the extent to which the colonized population and this new educated class gained access to bureaucratic posts. There are some scholars who argue that the development of civil society springs from higher levels of education and income. I make the argument here that the economic empowerment of colonized populations occurred around the same time that liberal education was extended to a larger swath of the population. In part, these dual occurrences are what I mean by colonial inclusion.

This first aspect of inclusivity fuels the second part of the concept, which is that the increase in educational attainment amongst the colonized population contributed to their increased desire for more posts within the colonial bureaucracy. Granted, there may have been contexts in which the colonized population received more education but were not given more opportunities within the state. However, the evidence explored in Chapter 5 on the Netherlands East Indies suggests that the expansion of educational access could serve the colonizers' intent to increase the number of bureaucrats needed to expand their colonial operation and impose state building (Matsuzaki 2019).

Therefore, colonial inclusivity reflects the extent to which the colonial regime provided liberal, western education to the colonized population, and this vehicle for socialization into classical liberalism had the effect of developing their civil society. Likewise, the investment in education served the colonial regime's purpose of increasing the number of bureaucrats to achieve their economic goals in the territory, while also developing a cadre of officials trained in running and building Weberian institutions. The 
amalgam of these factors is what I mean by colonial inclusivity, and I argue that its legacy continues to have implications for contemporary state capacity

Moreover, this this investigation of colonial inclusivity and state capacity argues that the relevance of institutional transmission in explanations of colonial legacy touted in the literature thus far is the function of a two-stage process. The vast majority of the literature thus far has assumed that the transmission of Weberian institutions occurs as the result of European settlement and, particularly, higher levels of European settlement relative to the colonized population. These assessments implicitly assume that the presence of European settlers alone is enough, while ignoring the process by which bureaucracies became stronger in Europe beginning in the $19^{\text {th }}$ century. Matsuzaki (2019) highlights the fact that the proto-bureaucracies in Europe were initially ineffective, because the hiring, training, and promotion practices were such that they lacked the professionalism and specialization that were the hallmarks of a rationally constituted bureaucracy. ${ }^{12}$ It was not until they implemented basic examination systems and in some cases forced all their aspiring bureaucrats to be trained at elite schools, as was the case in the French system, that the standardization of their training made them more effective bureaucrats. Moreover, Matsuzaki argues that this bureaucratic standardization was necessary for successful state building in Europe.

Given that the bureaucratic institutions in Europe had to go through a standardization process via education, and these were the same institutions that the literature claims were being transmitted in the colonies, it follows that an investigation

\footnotetext{
${ }^{12}$ In The Origins of Political Order, Francis Fukuyama (2011) identifies a rationally constituted bureaucracy as one where there is specialized education available to those with bureaucratic aspirations, exams are used for hiring decisions, and there is intentional cultivation of professionalized civil servants.
} 
into how this same process took shape in the colonies. Here, I assess the role of inclusive educational access as an intervening process for facilitating the institutional transmission and adoption by colonized populations prior to and after independence.

This investigation of an intervening process for colonial institutional transmission is also supported by Matsuzaki's (2019) argument that the ability of the colonial state to garner support or at the very least compliance from the population was through mediational institutions and intermediaries, who were able to sway the population and foster compliance with policies such as taxation and public health edicts. Due to their personal connection with the indigenous population, intermediaries were able to induce compliance in ways that traditional agents of the state (e.g. civil servants) were unable to. Even though this addition to the literature is useful, I do not believe it provides a complete picture of how state building success occurred.

Colonial inclusivity provides another missing link by arguing that the transmission of Weberian institutions occurs as a result of inclusive colonial education policies that not only increased compliance with the state but reinforced the legitimacy of the state-building effort and moved a critical mass of society towards endearment and civil service. Naturally, the use of education as a state-building tool was not employed in every colony. On one hand, I attribute this variation to the rise of classical constitutional liberalism in Europe and the shifting economic interests of the colonizer. On the other hand, there were international externalities that were also consequential for colonial policy such as economic shocks, and the World Wars of the early twentieth century. Thus, realities in the metropole were relevant for what occurred in the colonies. 
The second stage of this process is the actual implementation of the colonial education policy. As other scholars have mentioned, the success of implementation was contingent on several factors, such as local institutional structures (Mahoney 2010), the extent that the colonial state was able to enlist indigenous intermediaries to persuade the population to attend school (Matsuzaki 2019), factor endowments that dictated where and what resources were exploited (Bloom and Sachs 1998; Diamond 1997; Easterly and Levine 2003; Engerman and Sokoloff 2000; Hall and Jones 1999; Landes 1998; Sachs 2001) and whose perception of the population's value as human beings (Chatterjee 1993; Bhabha 1994; Go 2004; Said 1976; Todorov 1986). All of these factors would be difficult to tease out here, but in instances where these factors permitted the implementation of inclusive educational policies, these human-capital-creating institutions empowered the population. Additionally, it equipped the colonized population to enter the colonial bureaucracy if granted access, and meaningfully contribute to long-term state building efforts.

The overall process can be depicted as per Figure 3. This figure provides a typology of the complex causal process at play when thinking about how colonial education policy could influence contemporary state capacity. The overall causal process is obviously much too complex to test, such that my core hypothesis remains a simple one, which is that higher levels of colonial education lead to more effective states. The complex causal process through which this happens, and the historical roots of such colonial policies, are not tested in this dissertation, but a brief overview provides the intellectual context for the specific hypothesis I am advancing. 
Figure 2.3: Colonial Inclusivity and State Capacity

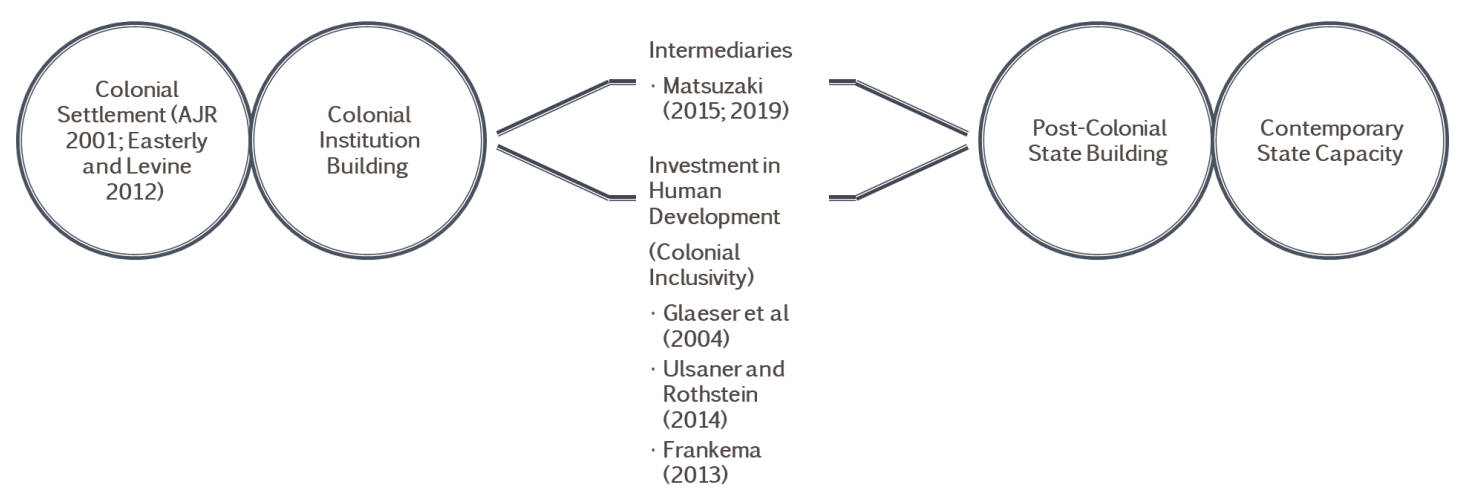

Below, I explain how the processes of the education mechanism serves state building and contemporary state capacity.

\subsubsection{The Metropole}

This theory of colonial inclusivity and state capacity begins with an assessment of how inclusivity takes shape during the colonial era. There are two factors that influence the metropole's adoption of inclusive colonial education policy. The first is the emergence of classical liberalism in Europe. The evolution of classical liberalism in Europe ultimately led to a shift in perceptions about individual rights and the role of the state in developing individuals. This shift that occurred in the metropole translated into their colonial policy in their occupied territories. It goes without saying to which the extent that classical liberalism trickled into colonial policy varied from one European power to the next and was influenced by their interests within a given colony, their 
perception of the colonized population, and the conditions on the ground. ${ }^{13}$ In colonies where there were higher levels of classical liberalism expressed in policies, there was a higher likelihood that educational institutions were built and expanded. The result of this colonial education expansion was the socialization of the colonized population into western norms. Thus, the emergence of classical liberalism in Europe contributed to colonial agendas that built civil society in the colonies in which it was expressed. This shift is important for state-society building, because the co-development of both is at the core of developing strong states (Migdal et al. 1994). The type of strong state I am interested in explaining here is the emergence and development of the Weberian state.

Prior to the $19^{\text {th }}$ century, colonialism was largely extract, as demonstrated by mercantilist colonial powers like Spain and Portugal (Mahoney 2010). Colonialism began to take a different form after the $19^{\text {th }}$ century due to policymaking shifts in Europe (Owolabi 2019). These policy shifts in Europe were due to the increasing popularity of classical constitutional liberalism in Europe, which emerged in the $18^{\text {th }}$ century but came to prominence in Europe during the $19^{\text {th }}$ century. Classical liberalism is distinct for giving precedence to individual freedom over excessive government encroachment on social, political, and economic life. For classical liberals, the government derives its legitimacy from the people, and the government is constrained by rule of law, with justice being meted out by codified processes and principles. Moreover, wealth is created by free individuals who are given the liberty to create, invent, invest, save, and exchange goods in a free market economy (Butler 2015). Distinct from his classical liberal counterparts who argued that the state should not have a monopoly over education, John Stuart Mill

\footnotetext{
${ }^{13}$ These conditions on the ground include the temperate climate, germs and diseases, and tensions between pre-colonial leaders and European powers.
} 
(1859) argued that, at the very least primary education, should be compulsory and provided by the state. Given JS Mill's influence, this addendum to the central tenets of classical liberalism arguably paved the way for the expansion of primary education in Europe, and eventually, in the colonies.

The materialization of classical liberal ideals most notably emerged in England. The political formation of this occurred as early as the $17^{\text {th }}$ century, with the likes of John Lilburne (1614-57) and Richard Overton (c. 1610-63) who were anti-establishment figures. They advocated for the end of state monopolies and the protection of freedom and equal rights (Butler 2015, 18). Fast forward to the latter half of the $17^{\text {th }}$ century during The Glorious Revolution, wherein William and Mary signed the Bill of Rights, which reinforced the rights and liberties of British subjects. This also granted the estranged Parliament stewardship over taxation, free elections, freedom of speech in Parliament, and the right to petition the government absent fear of retaliation $(2015,19)$. The Enlightenment, which mostly occurred during the $18^{\text {th }}$ century, facilitated the emergence of classical liberalism in England, and similar schools of thought that propagated individual freedom in France, Italy, Scotland, Germany, and the Netherlands.

Arguably, these ideological shifts in Europe had major implications for policymaking both domestically and abroad. Drawing from Mahoney $(2010,22)$, the political economy of a European nation at the time of its colonial project matters for the type of colonialism employed. In the timeframe explored here, the 19th and 20th centuries, the political economy of all the European colonial powers, was to varying degrees, liberal. Evidence from the Dutch and British East Indies suggests not only that Europe embraced liberalism ideologically, but also that this manifested itself in Europe's 
policy agendas (Butler 2015) and Europeans' perceived responsibilities to their respective colonies. For example, in the middle of the $19^{\text {th }}$ century Queen Wilhelmina of the Netherlands had Parliament pass the Dutch Ethical Policy, which reframed the nation's responsibility to its colonial territories, and articulated an obligation to provide opportunities for the human development of the colonized population.

The second factor that influences colonial inclusivity is the economic interest of the European colonizer. The European colonizer's economic interests reflected the conditions under which exploration of other territories was a desire or a necessity. The difference between colonial exploration as a "need" or "want" helped determine the sort of institutions or systems of governance colonial powers put in place, in order to achieve their economic goals in a territory. Throughout the $19^{\text {th }}$ century, there were significant economic shifts occurring in Europe that in some instances fueled a perceived necessity to explore areas that were more resource-rich. Thus, as constitutional liberalism spread in Europe and led to a shift in their perceived roles in the colonies, European colonizers also began to expand into new territories or deeper into existing protectorates to pursue their economic motivations. ${ }^{14}$ Notably, the British, Dutch, French, and Belgians began their expansions into resource-rich tropical Africa in the latter half of the $19^{\text {th }}$ century, just as the Dutch began to extend their reach in the Netherlands East Indies to the archipelago's outer islands. Given that tropical diseases inhibited extensive European settlement (Diamond 1997; Easterly and Levine 2003), this expansion coincided with the need to increase the skilled labor amongst the colonized population. Explicitly, the colonists needed some fraction of the colonized population to run the state institutions necessary

${ }^{14}$ I delve deeper into these motivations in the case studies of Indonesia and Malaysia in Chapters 5 and 6. 
for achieving their objectives in that territory. ${ }^{15}$ This economic necessity to empower the colonized populations contributed to state-building behavior and had the unintended consequence of building colonial civil societies as well. Again, the rise of classical liberalism and the desire for colonial expansion in the $19^{\text {th }}$ century watered the seeds of society and state building.

In sum, the existing literature has explored extensively—albeit not exhaustivelyhow state building resulted from European powers' desire to expand territorially and economically. From these investigations, there is a clear assumption that the natural outcome of European colonial powers extending the reach of the colonial state (Scott 1998) was to create Weberian institutions. Here, I provide a more nuanced explanation emphasizing how Europe's ideological and policy reforms, along with economic ambitions, led to the socioeconomic empowerment of some colonized populations. This becomes more evident in the next section, in the discussion of the development of colonial inclusivity and its effect on state capacity.

\subsubsection{The Colony}

The ideological and constitutional shift in Europe, along with colonial powers' economic spread across the globe lended itself to two processes that ultimately contributed to strong contemporary state capacity: 1) the creation of educational institutions helped build society and promote the economic empowerment of the colonized population; and 2) granting the colonized population access to posts within the

\footnotetext{
${ }^{15}$ Naturally, the type of institutions implemented and their perceived responsibility is also filtered through racialized prisms. Many of the European colonizers saw the world as divided between those who were full, rational humans and "savages". The shift in perceived responsibility towards colonial populations was predicated on whether the colonizers recognized their humanity. Granted, this recognition of humanity was at varying degrees.
} 
bureaucracy furthered state building. These two factors working together contributed to the long-term endurance of Weberian institutions. Additionally, these two processes occurred in many contexts almost simultaneously such that they reinforced each other.

Furthermore, these two processes are part of my core argument that investing in education for the colonized population and granting them access to the bureaucracy during the colonial period, would prove consequential for postcolonial state building. This is especially true when those bureaucratic posts were not superficial, but at higher levels. The following exploration of western bureaucracies and their interaction with education provides evidence for how the processes outlined here reinforced each other and led to strong contemporary state capacity.

While scholars go back and forth on what comprises a bureaucracy, here I use the Weberian definition of bureaucracy. Sociologist Max Weber (1922|2013) defined the characteristics of a modern bureaucracy as follows:

1. Bureaucrats are subjected to authority only within fixed parameters and are free otherwise;

2. Bureaucrats are organized into hierarchical offices with fixed parameters;

3. Each of these offices have a definite sphere of influence;

4. Hiring for each office is done via a free contractual relationship;

5. Technical qualifications or merit is the basis of selection for job candidates; and

6. Bureaucrats are compensated with fixed salaries.

Fukuyama (2013) offered a few useful modifications to the Weberian definition of a bureaucracy by adding that the level of education and the professionalization of the 
bureaucracy matters. In order to achieve the bureaucracy that Weber envisioned, Fukuyama argued that education is important, because it engrains those entering public service with a sense of commitment to the broader goals of the public and creates norms for the profession. Education also has the effect of inhibiting patronage and corruption (Evans and Rauch 1999, 752). This observation is extended by Ulsaner and Rothstein (2014) who link mass education in 1870 to corruption levels in 2010, arguing that more equitable education empowers citizens to oppose corruption within the state.

The connection between a professionalized bureaucracy and education is central to this study and is supported by the existing literature. The core features of a bureaucracy are the presence of fixed parameters, in terms of scope, salaries, and hiring practices, in addition to the importance of having a professionalized and educated bureaucracy. Since the record suggests that education is a necessary precondition for a Weberian bureaucracy, I argue that there is a level of intentionality that comes with building a bureaucracy, and that this intentionality in state building-rather than the alternative of happenstance - was not only a feature of bureaucracies in Europe, but also in some territories European colonial powers sought to dominate. If the goal was to build an effective bureaucracy, particularly in colonies where the level of settlement was dampened by the territory's geographic location (Landes 1998) or high mortality because of germs (Diamond 1997; Easterly and Levine 2003), the metropole had to be intentional about extending education to the indigenous and/or migrant slave populations (Owolabi 2019). Again, this did not occur in all colonies, and this varied across time within colonies. Moreover, Green (1990) argues that skilled labor that stems from higher levels of human capital (i.e. levels of educational attainment) within a population is essential for 
effective state building. Herein lies the relevance of colonial inclusivity for understanding the legacy of colonialism—-for better or for worse.

This concept, colonial inclusivity, reflects the level at which the European settlers invested in the human capital of the colonized population, and the degree to which the colonized were incorporated into the state. There are two things functioning in this concept: 1) I presume the primary form that human capital investment took was via educational policies that led to corresponding levels of educational attainment; and 2) investing in education equipped the colonized population with the skills necessary to participate in Weberian institutions that were built or modified by European settlers.

This concept is rooted in the reality that colonialism was pervasive and that it changed the structure of society, at least at the center of colonial operations. Note that these centers often became the central government after independence. First, I argue that colonial practices were so pervasive and so successful in upending traditional socialization and mobility structures (Banerjee \& Prasad 2008; Young 2004), that education was necessitated as a substitute. It should be noted that this destruction of traditional structures was less pronounced in large territories like India, or in territories with massive insurrection from pre-colonial authorities that maintained legitimacy, such as in many African territories. Second, for better or worse the new game in town was Weberian institutions that were devised to constrain the political, social, and economic interactions of society (North 1991). Thus, for state building to occur in the long term, members of the colonized population — even if it was only a select few—needed to be acclimated to the institutional practices they were inheriting to sustain and build upon them. 
Naturally, the necessity of extending education to the indigenous or migrant slave population varied based on a number of factors: 1) the number of European bureaucrats settled in the territory (Acemoglu, Johnson, and Robinson 2001); 2) the land mass the colonizer desired to subdue; 3 ) the level of cooperation from the colonized and their leaders (Mahoney 2010; Matsuzaki 2019); 4) the economic conditions in the colonizing state (Mahoney 2010); 5) pre-colonial conditions limited or permitted greater liberty in building new institutions (Easterly and Levine 2012); and I add 6) the level of liberalization in the colonizing state. In this project, rather than engaging in a 2SLS assessment of all of the pre-conditions for colonial education policy, I test the relationship between level of educational attainment and prominent indicators of state capacity in Chapter IV.

\subsection{Summary}

A recurrent theme throughout the literature is that institutions are important for economic growth. This study provides an excellent point of departure for assessing what factors contributed to the transmission of colonial institutions and the successful adoption

of those institutions before and after independence. One piece of this puzzle is Matsuzaki (2019) who argues that mediational institutions aided the colonial state in gaining compliance with its policy. I extend this further by arguing that the provision of education to more than just elites in the colonized population helped socialize the population and legitimize the state. In the long-term, this helped equip the population for the state building that has produced contemporary state capacity in the post-colonial world. 
Furthermore, inclusive colonial education policies were most likely to be implemented in contexts where ideological shifts had occurred in the metropole, and this often but not always lent itself to greater access to the civil service. I also argue that when inclusive colonial education policies were present, the population was equipped to participate in state building during and after the colonial period. These things working in tandem and influenced the transmission of Weberian institutions akin to the Western world. It is important to note that this is not a statement about whether that was good or bad, but rather that state building that was reflective of western norms was most likely to occur in contexts where the colonized population was given access to western education and positions within the colonial state.

Lastly, these processes also had the effect of extending economic rights to the colonized population. This is important, because Banerjee and Iyer (2005) note that the extension of property rights to cultivators rather than landlords during the colonial period was critical to economic development after independence. Evidence from Indonesia suggests that the extension of property rights to the colonized population was a precursor, not necessarily a cause, to the expansion of education beyond the European settler population to the colonized population. An improvement on Banerjee and Iyer's (2005) argument is that the confluence of economic empowerment and higher levels of educational attainment contributed to the increased demand for positions of power in government from the native population in Indonesia, leading to the founding of the native corps of bureaucrats. This ultimately had implications for state building in the period just before independence and after independence. I assess this observation more closely in Chapter V and make inferences about its occurrence in other colonial contexts. 


\section{Chapter III: COLONIAL SETTLEMENT AND STATE CAPACITY IN POST-COLONIAL STATES}

The ongoing effect of colonial institutional quality on economic performance in post-colonial states has been of great interest to scholars in and outside of political science. Seminal works like Acemoglu, Johnson, and Robinson (2001) have emphasized the relationship between European colonial settlement levels' indirect effect on long-term economic development through institutional quality, as an explanation for divergent outcomes in the post-colonial world.

In this chapter, I explore in greater depth the first part of Acemoglu, Johnson, and Robinson's (2001) argument, the intervening process in which the level of settlement affects the quality of state institutions. In addition to Acemoglu, Johnson, and Robinson (2001), there are a number of scholars who argue that the percentage of the European population in colonial territories had a positive effect on their development via institutions (Banerjee and Iyer 2005; Feyrer and Sacerdote 2009; Sokoloff and Engerman 2000). Here, I empirically assess the relationship between the level of European settlement and its enduring effect on contemporary state capacity in former colonies. I do this by testing the relationship between the prominent operationalization of colonialismlevel of European settlement - and the four indicators of state capacity (government effectiveness, bureaucratic quality, political constraints, and tax ratio) in 62 former colonies. Therefore, in this chapter I do not assess the relationship between my colonial inclusivity and contemporary state capacity, but rather focus on the predominant strategy scholars use to measure colonial legacy - the level of European settlement. Through an examination of the effect of the level of European settlement on a tripartite formulation of 
state capacity--administrative, institutional, and fiscal capacity - I find that higher levels of European settlement had a positive effect on administrative and institutional capacity.

This chapter makes two contributions to the social science literature on colonialism. First, this investigation deepens our understanding of colonial legacy by empirically assessing the causal relationship between the conventional measure of colonialism and a prominent explanatory variable — state capacity. Second, this investigation unpacks the nuances of state capacity and provides a more comprehensive way of conceptualizing and measuring the concept. I hypothesize and confirm that higher levels of European settlement had a positive effect on the forms of state capacity explored here-administrative, institutional, and fiscal capacity. These forms are part of the general understanding of state capacity and its diverse manifestations, which amounts to the ability of the state to implement its disparate preferences and resources into policies and services. ${ }^{16}$ These two contributions are important for this study of the intervening processes that led to institutional transmission, because it lays the groundwork for connecting colonialism to contemporary state capacity, before delving further into the practices of settlers once they arrived.

As a brief overview of the methodology employed here, I test the relationship between European colonial settlement and state capacity, using four variables that are prominent in the literature on state capacity. In order to provide a more comprehensive operationalization of the concept, I employ bureaucratic quality from the International Country Risk Guide (ICRG) (PRS, 2006); government effectiveness from the Worldwide

\footnotetext{
${ }^{16}$ While the state is often defined as an entity with a monopoly over coercive force or violence (Tilly, 1985), I do not examine the relationship between the percentage of European settlers or level of settlement, and the coercive capacity of the state.
} 
Governance Indicators (World Bank 2013); and tax revenue as a percentage of GDP (Gross Domestic Product) from the World Bank (World Development Indicators 2016); and the political constraints index (Henisz, 2000). I organize these variables into a threepart typology: administrative capacity (i.e. bureaucratic quality and government effectiveness); institutional capacity (i.e. political constraints index); and fiscal capacity (i.e. tax revenue as a percentage of GDP).

To test the hypothesis that the level of European settlement matters for state capacity, I utilize a cross sectional statistical test of the measures of state capacity, using 62 observations from 2010 for the dependent variable. I find that a higher percentage of European settlers has a positive and significant effect on the three facets of state capacity in post-colonial states, even though the effect of settlement on fiscal capacity is not as pronounced. I also find a negative and significant relationship between settler mortality rate and state capacity. This affirms the Acemoglu, Johnson, and Robinson's (2001) argument about the importance of favorable conditions for a higher percentage of European settlers and the resulting institutional quality. While the results of this study reinforce their argument, my contribution to the literature on state capacity and economic development is that colonialism as it is presently conceived in the literature has an effect on contemporary state capacity. This empirical assessment is the basis for this study of how European settlement matters for the transmission and adoption of Weberian bureaucratic institutions.

In the next section, I revisit the discourses on colonial settlement and state capacity that motivate this study. Then, I make an argument for the relevance of studying state capacity as a dependent variable, with colonialism as the main explanatory variable. 
After this, I explain the research design of this chapter followed by an explication of the analyses and results. I conclude with a discussion of the results, the importance of moving this line of research forward, and the potential for addressing future research topics.

\subsection{Level of Settlement and Institutional Quality}

Prior to and since the seminal work of Acemoglu, Johnson, and Robinson (2001), the literature on political economy has focused on the effect of colonialism on economic development in post-colonial states (Englebert 2000; Engerman and Sokoloff 2002; Lange 2003: 2009). Scholars that assess colonialism's effect on economic growth can be organized into four explanations: 1) institutional incongruence between pre-colonial and post-colonial institutions can explain the divergence in economic growth and to a certain extent state capacity (Englebert 2002); 2) colonial institutional arrangements were inherently adverse to long-term growth particularly for colonies with high inequality (Engerman and Sokoloff 2002); 3) the building of bureaucratic structures and the embeddedness of the colonial apparatus fostered a "state-society synergy" leading to effective institutions for long term development (Lange 2003); and 4) variation in general colonial strategies by different colonial regimes led to divergent outcomes in economic growth (Lange, 2009).

To a lesser extent, there have been a few studies that explicitly assessed the relationship between colonialism, state building, and state capacity (Migdal 1988; 2009; Fukuyama 2004; Englehart 2005; Hameiri 2009). While their historical analyses are helpful for understanding the intuitions behind how colonialism still matters, they stop 
short of empirically assessing the relationship between colonialism and contemporary state capacity. Given the value of empirical evidence, an empirical test would only help to strengthen their claims about the effect of colonialism on contemporary state capacity. Thus, this chapter aims to fill this lacuna by first statistically exploring the relationship between these two prominent indicators. In chapter IV, I empirically assess the more nuanced approach presented in chapter II.

Before investigating the main contribution of this study, it is important to reflect on one of the first statistical examinations of the effect of colonialism on institutional quality—a derivative of state capacity—initially put forth by Acemoglu, Johnson, and Robinson (2001). They argue that extraction or violent exploitation of resources in colonies and the erection of absolutist governments adversely affected institutional quality in former colonies. The level of exploitation depended on the percentage of European settlers in relation to the colonized population, which influenced the structure of the colonial government. Settler colonies or colonies with high European settlement were typically modeled after the home country, which they intuit led to higher quality institutions after independence $(2001,1574)$. Alternatively, they argue that in non-settler colonies there was greater motivation to focus on economic exploitation, which led to the erection of predatory institutions--akin to Belgian colonization in the Congo--for extraction purposes $(2001,1575)$. This part of Acemoglu, Johnson, and Robinson's argument stems from early scholarship that suggests that the extractive institutions set up by European settlers persisted long after decolonization (Young 1994). The internal logic of their argument is that extractive and predatory institutions persisted after independence due to: 1) the costliness of setting up institutions that respect property rights; 2) the size 
of the selectorate or the ruling elite who had an incentive to maintain the status quo; and 3) the fact that these agents of the state may have only been willing to invest in property rights institutions if they had more to lose. Yet, it seems that institutions persisted even in colonies with few or no predatory institutions, which suggests that we should focus on why colonial institutions in general persisted.

\subsection{Why Study State Capacity?}

While property rights are heavily studied in the economic literature, political scientists have a much broader conceptualization of state capacity. Generally, the assessment of state capacity as an explanatory factor for economic development is prevalent in political science scholarship (Besley and Persson 2010; Doner 1992; Doner, Richie, and Slater 2005; Englehart 2009; Fukuyama 2004; Migdal et al. 1994; Slater 2005; Winters 2011). Presently, the literature has not come to a consensus on what state capacity is and how it should be operationalized. Understanding state capacity is important, because state practice directly affects global health, environmental health, and human rights. Therefore, the implications that high or low levels of state capacity have for the quality of life for people around the world make understanding state capacity an important topic in its own right. In this chapter, I assume that the capacity of the state can be organized into three forms: 1) administrative capacity; 2) institutional capacity; 3) and fiscal capacity.

This understanding of state capacity is informed by the broader comparative politics literature on state building, and the political economy literature on economic

development. Some of the earliest assessments of state capacity can be traced back to 
Theda Skocpol (1985) who advocated for bringing the state back into political science analyses. From there, Barbara Geddes (1994) argued that state capacity is the state's ability to implement decisions and translate its preferences into action. Some scholars argue that state capacity is comprised of four functions rather than one (i.e. institutional, technical, administrative, and political capacity) (Grindle, 1996), ${ }^{17}$ or that at the very least a distinction should be made between its scope and strength (Fukuyama, 2004). While Grindle's (1996) formulation of state capacity is one of the few that contemplate different forms of capacity, there is some overlap between administrative capacity (i.e. the ability of the state to make informed and rational decisions on how to exercise its power) and technical capacity (i.e. the ability of the state to organize itself and its resources for the public good). In the typology utilized here, I use this as justification to combine these two factors.

Apart from the state building literature, the most prominent conceptualizations and operationalizations of state capacity are economically based, in part because data for economic variables are more readily available. As mentioned previously, this understanding of state capacity is often used as a key explanatory variable or control variable in the economic development literature. One of the most prominent economic measures of state capacity is the ability to raise revenue via taxation (Besley and Persson 2009; Campbell 1993; Cheibub 1998; Englehart 2005; Fauvelle-Aymar 1999; Levi 1998; Lieberman 2002; Tilly 1975). Additional economic interpretations of state capacity

\footnotetext{
${ }^{17}$ Merilee Grindle (1996) defines institutional capacity as the state's competence in enforcing and designing laws that regulate economic and social relationships, as well as the rule of law. Technical capacity is the state's ability to make rational and informed decisions on how best to exercise power. Administrative capacity is the state's ability to organize itself and resources for the public good. Finally political capacity is the state's accountability and responsiveness to the wishes of citizens.
} 
include the investment environment (Fearon 2005), or other economic indicators such as export profiles, natural resources, and extractive capacity as a proxy (Humphrey, 2005). These economic interpretations of state capacity on their own oversimplify the capacities necessary for governance. Effective governance requires codified institutions and a trained bureaucracy, and thus economic and political operationalizations of state capacity should be considered together rather than on their own.

More recently, state capacity has been conceptualized as both bureaucratic quality (DeRouen and Sobek 2004) and tax capacity (Hendrix 2010). Hendrix (2010) argues that state capacity is "professionalism, insulation from political pressure, and efficacy in delivering government services $(2010,278)$." Yet, Hendrix operationalizes state capacity as simply bureaucratic quality, which does not capture the importance of the rule of law (Winters 2011), or institutional constraints on bureaucratic power. Some scholars have made the concept nearly coterminous with regime type (Vreeland 2008) and democracy, arguing that state capacity is indicated by the degree that democratic features are part of the political system (Gurr 1974; Hegre et al. 2001; Marshall and Jaggers 2009; Fearon and Laitin 2003). Others have made the concept coterminous with a coercive or military capacity (Henderson and Singer 2000). Like the economic interpretations of the concept, these interpretations oversimplify the vital aspects of effective states.

Presently, the concept is a moving target, and the literature assessing what the concept is, and what affects it is a far cry from the demands of other literature, such as democracy. As a departure from the literature, I assess state capacity as the dependent variable and define state capacity as the ability of state officials to translate their disparate preferences into policies and services that serve either themselves or their populations. I 
make this distinction, understanding that some states have a strong state capacity in all areas, (e.g. Singapore), but do not necessarily act in favor of their constituents.

Nonetheless, state capacity is the ability of state entities to translate their preferences into choices (i.e. policies). The capacity of states is determined by the strength of administrative, institutional, and fiscal capacity. If a state has high administrative capacity, it has trained personnel, including technocrats who are efficient in organizing themselves and their resources, and can make informed and rational decisions. A state with strong institutional capacity has the ability to regulate socioeconomic relationships, including designing and enforcing laws, which is contingent upon having established and respected institutions. Finally, a state with strong fiscal capacity has the ability to raise revenues and allocate those resources as a vehicle for its preferences.

A deficit in each of these facets is detrimental for state capacity as a whole. First, when administrative capacity is weak, there is the potential for lags in the provision of public services, such as transportation and public sanitation. Also, bureaucrats are more susceptible to political pressures, and may even succumb to public pressures by taking bribes from elites. Second, when institutional capacity is weak, the state has the potential to have weak, dependent courts and lack veto powers, which can lend itself to rule by law, ${ }^{18}$ rather than rule of law. Lastly, when fiscal capacity is weak, the state is potentially incapable of raising revenues, or maybe effective at raising revenues, but poor at allocating funds to serve its preferences absent collusion by powerful actors within and outside the state. As a whole, when state capacity is weak, the state can be plagued by

\footnotetext{
${ }^{18}$ Acemoglu and Robinson (2012) make a distinction between rule of law and rule by law, by pointing out that rule by law is the monopoly over the enforcement of laws wherein elites have the power to administer the law as they see fit, while avoiding subjugation to the law (2012: 298-304).
} 
rampant corruption that further eats away at the resources of the state and its effectiveness.

If Acemoglu, Johnson, and Robinson (2001) are right about the significance of European settlement (i.e. the percentage of the population of European descent in 1900) for institutional quality, a derivative of state capacity, then this relationship should hold for the tripartite conceptualization of state capacity put forth here. I therefore hypothesize this relationship as follows:

Hypothesis 1: A higher percentage of European settlement during colonization, contributes to higher levels of administrative capacity after independence.

Hypothesis 2: A higher percentage of European settlement during colonization, contributes to higher levels of institutional capacity after independence.

Hypothesis 3: A higher percentage of European settlement during colonization, contributes to higher levels of fiscal capacity after independence.

The null hypothesis of these claims is that the percentage of European colonial settlers has no effect on these three facets of state capacity after independence.

In post-colonial states with a higher percentage of European settlers, these three facets of state capacity should be strong, because European settlers brought liberal ideals and traditions to their colonies. At the height of the colonial enterprise in the 18th century, Europe experienced an Age of Enlightenment that shifted their form of governance, and the relationship between those that govern and the governed. From this age emerged liberal ideas such as legitimacy, liberty, constitutional democracy and rule of law, which also contributed to the revolutions that broke out in Western Europe. These 
new ideals infiltrated the governance practices of European states and America, and arguably some of those traditions were transmitted to the colonies through institutions during the colonial era. Thus, the three facets of state capacity were affected by the diffusion of these ideals to the colonies during the colonial era. This transmission process occurred via the provision of tertiary education, training segments of the indigenous population in European institutional traditions and offering hands-on experience in the administration of the state. Thus, a high percentage of European settlement increased the likelihood that this transmission process would occur, which would have lasting effects on the capacities of post-colonial states. These societal dimensions of institutional transmission are at the core of the broader investigation of colonial inclusivity explored empirically in the next chapter.

\subsection{Measuring State Capacity}

State capacity is often conceptualized and operationalized using more economic terms and variables. As alluded to earlier, the most commonly used measures of state capacity in the economic development literature are: total taxes/GDP ratio, total revenue/GDP ratio, or logged GDP per capita (Cheibub 1998; Fauvelle-Aymar 1999; Levi 1998; Lieberman 2002; Przeworski et al. 2000; Thies 2010; Tilly 1975); the level of production and proven past oil production or future reserves (Gereffi, Humphrey, and Sturgeon 2005); military expenditures as a percentage of GDP (Henderson and Singer 2000); and the repudiation of government contracts (Fearon 2005) taken from the International Country Risk Guide (ICRG) developed by the Political Risk Services Group. These economic measures of state capacity, with the exception of the repudiation of government contracts, only capture the extractive capacity of the state. The ability of 
the state to "get things done" or to translate their preferences into choices requires more than just extractive capacity. Institutions and trained personnel are also necessary for managing and properly allocating resources once they are acquired. The absence of training may contribute to corruption and the loss of state funds.

On the other hand, the most pervasive non-economic measures of state capacity include: the Polity index or Polity2 index (DeRouen and Sobek 2004; Fearon and Laitin 2003; Gurr 1974; Hegre et al. 2001; Marshall and Jaggers 2009; Vreeland 2008); bureaucratic quality from ICRG (Back and Hadenius 2008; DeRouen and Sobek 2004; Hendrix 2010) and government effectiveness from the World Bank's Worldwide Governance Indicators. ${ }^{19}$ The usage of the Polity Index to measure state capacity conflates regime type and institutional quality, even though the two are correlated. Likewise, bureaucratic quality and government effectiveness only capture the ability of the state to manage itself and fails to account for the ability of the state to raise and allocate resources effectively, among other factors that are relevant for the interpretation of state capacity here. Since the concept is recurring in the economic development and broader political science literature, it is important for scholars to find and utilize a conceptualization and operationalization of the concept that is comprehensive and empirically relevant for disparate contexts.

I opt for a tripartite operationalization of state capacity, which captures the diverse measures of the concept that have thus far been articulated in the literature and which is consistent with the conceptualization of state capacity that is proposed here. The three facets of state capacity — administrative, institutional, and fiscal — are captured

\footnotetext{
${ }^{19}$ For a more detailed explanation of the various measures of state capacity used in the literature, please see the appendix of tables.
} 
using four prominent measures of state capacity in the existing literature. Administrative capacity is measured using the World Bank's government effectiveness (Kaufmann, Kraay, and Mastruzzi, 2011) and bureaucratic quality (Howell, 2011), to compare the two measures. The first is more holistic in that it captures the quality of the bureaucracy, institutional effectiveness, and the quality of public services, whereas the second measure only captures bureaucratic quality. Concretely, government effectiveness is an index that:

[...] captures perceptions of the quality of public services, the quality of the civil service, and the degree of its independence from political pressures, the quality of policy formulation and implementation, and the credibility of the government's commitment to such policies. (Kaufmann, Kraay, and Mastruzzi, 2011).

Government effectiveness is an index ranging from [-2.5, 2.5], with negative values indicating poor governance, whereas positive values indicate good governance. The index is a composite of scores from various sources, including bureaucratic quality (Howell 2011). Even though there is some overlap between the two measures of administrative capacity employed here, I also use the raw index of bureaucratic quality to eliminate some of the "noise" that may be intrinsic to the 16 different sources that government effectiveness is derived from. Bureaucratic quality is an index from [0, 4], with the highest scores given to countries with bureaucracies that have the expertise and strength to govern without interruptions in government services or dramatic changes in policy (Howell 2011, 7).

Institutional capacity is measured using the political constraints index (Henisz 2000), which is a measure of the extent to which a change in the preferences of one political actor can lead to a change in government policy. This is adopted as a measure of 
state capacity, because some scholars in the foreign direct investment literature think that a state's institutional complexity is indicated by the number of veto players who potentially would reduce the ability of individual actors to expropriate state funds (Busse and Hefeker 2007; Li 2009; Neumayer and Spess 2005). To capture this logic, the political constraints index is a measure of veto players and the feasibility of policy change in 234 countries from 1800-present, with values ranging from [0,1]. These values can be interpreted as "[when] the number of actors with independent veto power increases, the level of political constraints increases" (Henisz 2005, 3). Finally, fiscal capacity is measured using each observation's tax revenue as a percentage of GDP (World Bank 2016). The numeric values of this variable are the tax revenue percentage of the GDP for each country, from [0,100]. For example, Malaysia's tax revenue collected by the central government in 2010 was $14.3 \%$ of the GDP, whereas Indonesia's tax revenue collected by the central government in 2010 was $10.9 \%$ of the GDP.

Additionally, I evaluate the extent to which these measures are in fact separate measures of state capacity. The correlation between World Bank government effectiveness and ICRG bureaucratic quality is high at (0.91), which is expected given that the index for both variables is coded similarly, and because bureaucratic quality is one of the factors included in the government effectiveness indicator. The correlations between the political constraints index and government effectiveness and bureaucratic quality are high as well at (0.65) and (0.61) respectively. The correlations between tax as a percentage of GDP and the other variables are fairly low at 0.35 for government effectiveness, 0.35 for bureaucratic quality, and 0.21 for the political constraints index. While the correlation between government effectiveness and bureaucratic quality is high, 
I still believe that it is important to handle these separately and compare the effect of European settlement during colonialism on these alternative measures that are prominently used in the literature on state capacity and economic development.

\subsection{European Colonial Settlement and State Capacity}

In order to test the relationship between colonialism, operationalized as the level of European settlement, I first utilize data from Acemoglu, Johnson, and Robinson (2001) to replicate Table III from their analysis, which contains several estimates of the determinants of institutions. In Tables I-II, I replicate the most relevant aspects of their assessment for this study using regression analysis on two operationalizations of institutional quality (i.e. average protection against expropriation risk and constraint on the executive). ${ }^{20}$ In model 7 and 8 of Table I, I replicate Acemoglu, Johnson, and Robinson's (2001) analysis of the relationship between European settlement in 1900 and average protection against expropriation risk in 1985-1995 and find a positive and significant relationship when latitude is excluded from the model $(3.18, \mathrm{p}<0.01)$, and when latitude is included in the model $(3.00, \mathrm{p}<0.01)$. In models 1 and 2 , I also replicate their assessment of constraints on the executive in 1900 and average protection against expropriation risk and find a positive and significant relationship $(0.32, \mathrm{p}<0.01)$. This effect remains even when assessing constraint on the executive one year after independence $(0.24, \mathrm{p}<0.01)$, which suggests that the institutional complexity of the colonial regime was eradicated by independence.

[Table 1 about here]

\footnotetext{
${ }^{20}$ Descriptions of all of the variables included in this analysis can be found in the Appendix A table, which is derived from Appendix Table 1 of Acemoglu, Johnson, and Robinson (2001) on p. 1397.
} 
This intuition is supported by Acemoglu, Johnson, and Robinson's (2001) test of the aforementioned relationships on constraint on the executive in 1900. In Table II, I replicate AJR's (2001) findings on the extent that European settlement and log settler mortality affects the constraint on the executive in 1900. In model 2, I find that a higher percentage of European settlers in 1900 has a strong and positive relationship with constraint on the executive in $1900(0.05, \mathrm{p}<0.01)$, such that a 1 percent increase in the number of European settlers, increases the constraint on the executive by 0.05 . Given that the constraint on the executive in 1900 is on a scale from [1, 7], an increase of 0.05 is substantial. Alternatively, log settler mortality has a negative and significant relationship with constraint on the executive in $1900(-0.51, \mathrm{p}<0.01)$, which suggests that a decrease in the level of settlement as a result of high mortality is detrimental to the constraints on the executive at the turn of the twentieth century, a key feature of institutional capacity.

[Table 2 about here]

Using AJR's (2001) analysis as a point of reference, I utilize Fails and Krieckhaus' (2010) level of European settlement indicator to estimate the effect of the percentage of European settlement on the three categories of state capacity. Beginning with Table III, I estimate the relationship between the tripartite measure of state capacity — administrative, institutional, and fiscal capacity — and the level of European settlement in 2010 in separate models. I measure administrative capacity as World Bank government effectiveness and ICRG bureaucratic quality. Institutional capacity is operationalized as the political constraints index, while fiscal capacity is operationalized as World Bank tax revenue to GDP ratio. 
In model 1 and 2, I find a significant and positive relationship $(\mathrm{p}<0.01)$ between the level of European settlement and administrative capacity, with both government effectiveness $(2.33, \mathrm{p}<0.01)$ and bureaucratic quality $(0.56, \mathrm{p}<0.01)$ increasing as the level of European settlement increases. Similarly, in model 3 I find a positive and significant relationship between institutional capacity and the level of European settlement, with the effect on the political constraints index being $(0.47, \mathrm{p}<0.01)$. I also find a positive and significant relationship between level of settlement and fiscal capacity operationalized as the tax ratio $(5.43, \mathrm{p}<0.10)$. These results provide strong evidence for hypothesis 1 and 2 that higher levels of European settlement increase administrative and institutional capacity and confirms the AJR (2001) argument that the level of European settlement matters for institutional quality. Furthermore, the significance of each operationalization confirms the complexity of state capacity and provides credence to the tripartite definition employed here, while at the same time uncovering the relevance of examining colonialism's effects on different facets of state capacity.

Notably, the level of settlement seems to have its biggest effect on administrative capacity, with government effectiveness increasing by 2.32 with a higher percentage of European settlers. This is striking, because government effectiveness is on a scale from [$2.5,2.5]$, with positive values equating to higher government effectiveness. However, this effect is also strong for the other indicators. For instance, bureaucratic quality is on a scale from $[0,4]$, which means that an increase in the quality of the bureaucracy by 0.56 is substantial. Likewise, the variable for institutional capacity is a on a scale from $[0,1]$, which means that an increase in political constraints by 0.47 is also a substantive effect. 
Interestingly there is a significant, but not as pronounced relationship between the level of settlement and fiscal capacity.

[Table 3 about here]

In Table IV, I estimate the effect of log settler mortality on the tripartite measure of state capacity. In their analysis, AJR (2001) explored the possibility that the percentage of European settlers may create some endogeneity issues, because these percentages might be influenced by political conditions in the colonies. They proxy settler mortality as a truly exogenous measure, even though one could argue that settler mortality can also be influenced by political conditions and not just environmental issues. I also utilize this as an alternative measure of colonialism in the models depicted on Table IV. As expected, I find a negative and significant relationship $(\mathrm{p}<0.01)$ between log settler mortality and all four operationalizations of state capacity. It appears that log settler mortality may have a larger negative effect on fiscal capacity, than the positive effect of level of European settlement on fiscal capacity.

[Table 4 about here]

\subsection{Robustness Checks}

Concerning the OLS assumptions, I will now discuss the tests of these assumptions for the models in Table III. For each of the models, I found that the errors are homoscedastic and therefore do not require correction.

There are, however, some outliers in the model such that I tested for leverage. I found that the highest leverage states are Argentina, United States, New Zealand, Australia, and Canada (graphically depicted by Figure 1). This can be expected given the 
fact that these were colonies with high concentrations of European settlement, with a smaller indigenous populations and minimal pre-existing structures that would make a "blank slate" of state formation difficult. ${ }^{21}$ In order to correct for leverage, I re-estimated the models using robust regression, which is sensitive to outliers and high leverage points. A robust regression, which uses Huber weight functions, minimizes the high residuals of outliers and high leverage observations. It is $95 \%$ as efficient as OLS (Huber 1981).

Table V depicts the outcome of the robust regression estimate of the models from Table III. The results of this analysis are quite similar, except for the effect of level of European settlement on fiscal capacity $(6.23, \mathrm{p}<0.05)$, which suggests that the outliers dampened the effect of settlement on the fiscal capacity of states.

[Figure 1 about here]

[Table 5 about here]

\subsection{Summary}

Acemoglu, Johnson, and Robinson (2001) had a strong influence on the economic development literature, particularly as it relates to the legacy of colonialism for the longterm economic growth of post-colonial states. A key feature of their causal narrativecolonial extraction precipitates institutional quality, which precipitates long term economic growth — has yet to be fully explored. As an extension of their argument, I have explored how European settlement affects a prominent explanatory variable, state capacity, in and outside the economic development literature. This exploration is

${ }^{21}$ Granted, the pre-existing populations that existed were exterminated by European settlers, such as the annihilation of Native Americans in the future United States and aborigines in Australia. 
important, because political scientists have not come to a general consensus about what state capacity is, nor have we empirically assessed what contributes to weak and strong state capacity. This is especially important for post-colonial states that are often plagued by slow economic growth, and in some instances inefficient and ineffective governments, which contribute to a whole slew of other issues that affect their populations.

The results of this analysis suggest that when the relationship between the level of settlement and measures of contemporary state capacity are analyzed, there is still a strong and positive effect on administrative capacity and institutional capacity. This relationship is not as strong for fiscal capacity (tax revenue as a percentage of GDP). This supports my hypotheses and suggests that the level of settlement matters for post-colonial state capacity. Lastly, in order to adequately operationalize this complex concept, it is important for scholars to disaggregate using prominent indicators that are already in use in the literature, in order to capture the multidimensional aspects of state capacity.

In the future, more research will need to be done to assess the causal mechanisms that connect level of settlement and the colonial enterprise with post-independence governance. In the next chapter, I delve further into the connection between efforts to transmit liberal, Weberian institutions to society via human capital-creating institutions. 


\subsection{Tables and Figures}

Table 3.1: AJR(2001) Average Protection Against Expropriation Risk in 1985-1995

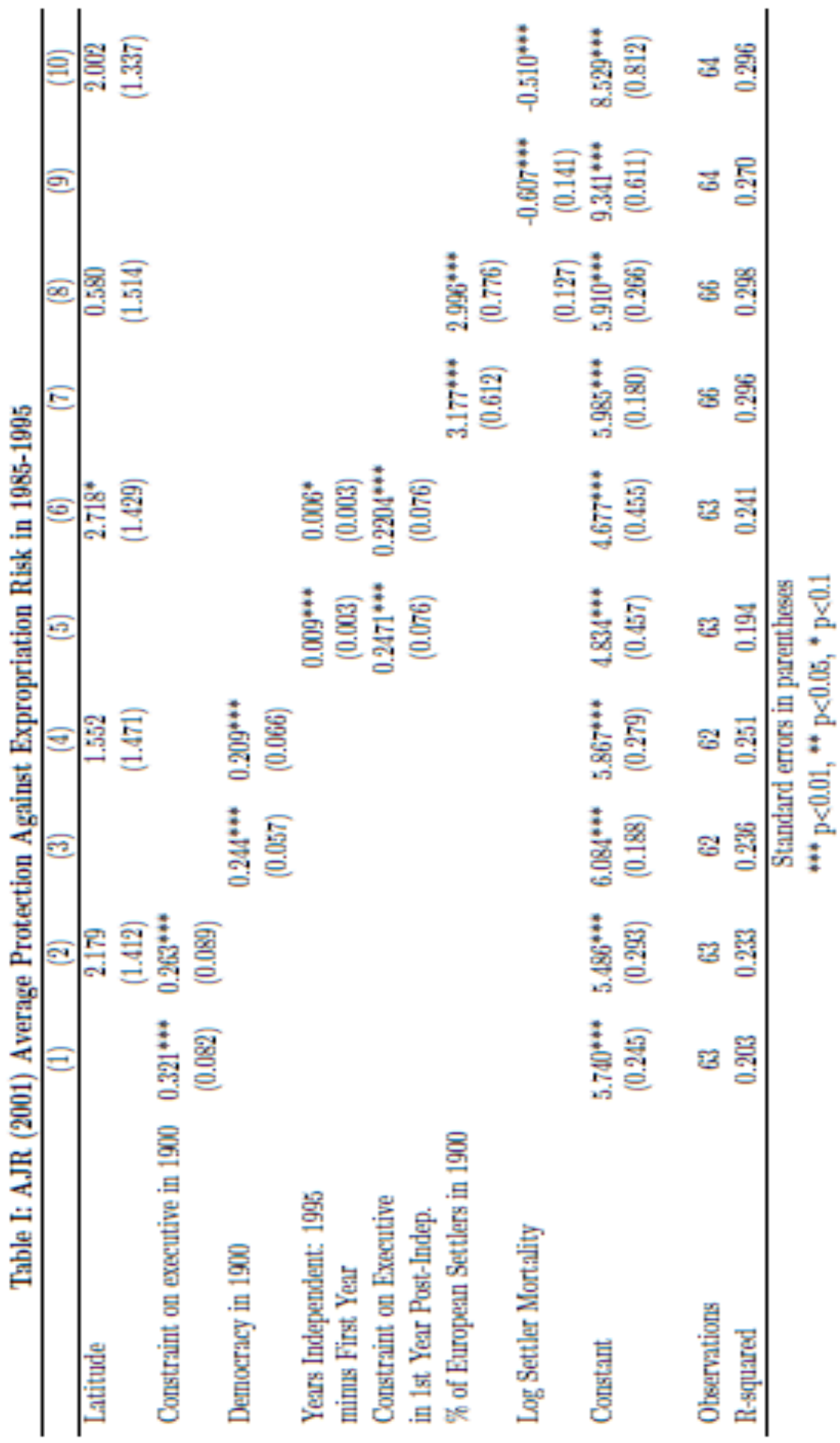


Table 3.2: AJR(2001) Constraint on Executive in 1900

Table II: AJR (2001) Constraint on Executive in 1900

\begin{tabular}{|c|c|c|c|c|}
\hline & $(1)$ & $(2)$ & $(3)$ & $(4)$ \\
\hline Log Settler Mortality & $\begin{array}{c}-0.510^{\text {*** }} \\
(0.141)\end{array}$ & & $\begin{array}{c}-0.821^{* * *} \\
(0.167)\end{array}$ & $\begin{array}{c}-0.654^{* * *} \\
(0.182)\end{array}$ \\
\hline Latitude & $\begin{array}{c}2.002 \\
(1.337)\end{array}$ & $\begin{array}{c}0.333 \\
(1.809)\end{array}$ & & $\begin{array}{c}3.634^{* *} * \\
(1.716)\end{array}$ \\
\hline$\%$ of European Settlers in 1900 & & $\begin{array}{c}0.054^{* * * *} \\
(0.009)\end{array}$ & & \\
\hline Constant & $\begin{array}{c}8.529^{* * *} * \\
(0.812)\end{array}$ & $\begin{array}{c}1.206^{* * *} \\
(0.317)\end{array}$ & $\begin{array}{c}5.879^{* * * *} \\
(0.814)\end{array}$ & $\begin{array}{c}4.460^{* * * *} \\
(1.040)\end{array}$ \\
\hline Observations & 64 & 70 & 75 & 75 \\
\hline R-squared & 0.296 & 0.456 & 0.248 & 0.292 \\
\hline
\end{tabular}


Table 3.3: Measures of State Capacity in 2010 and Level of European Settlement (1900)

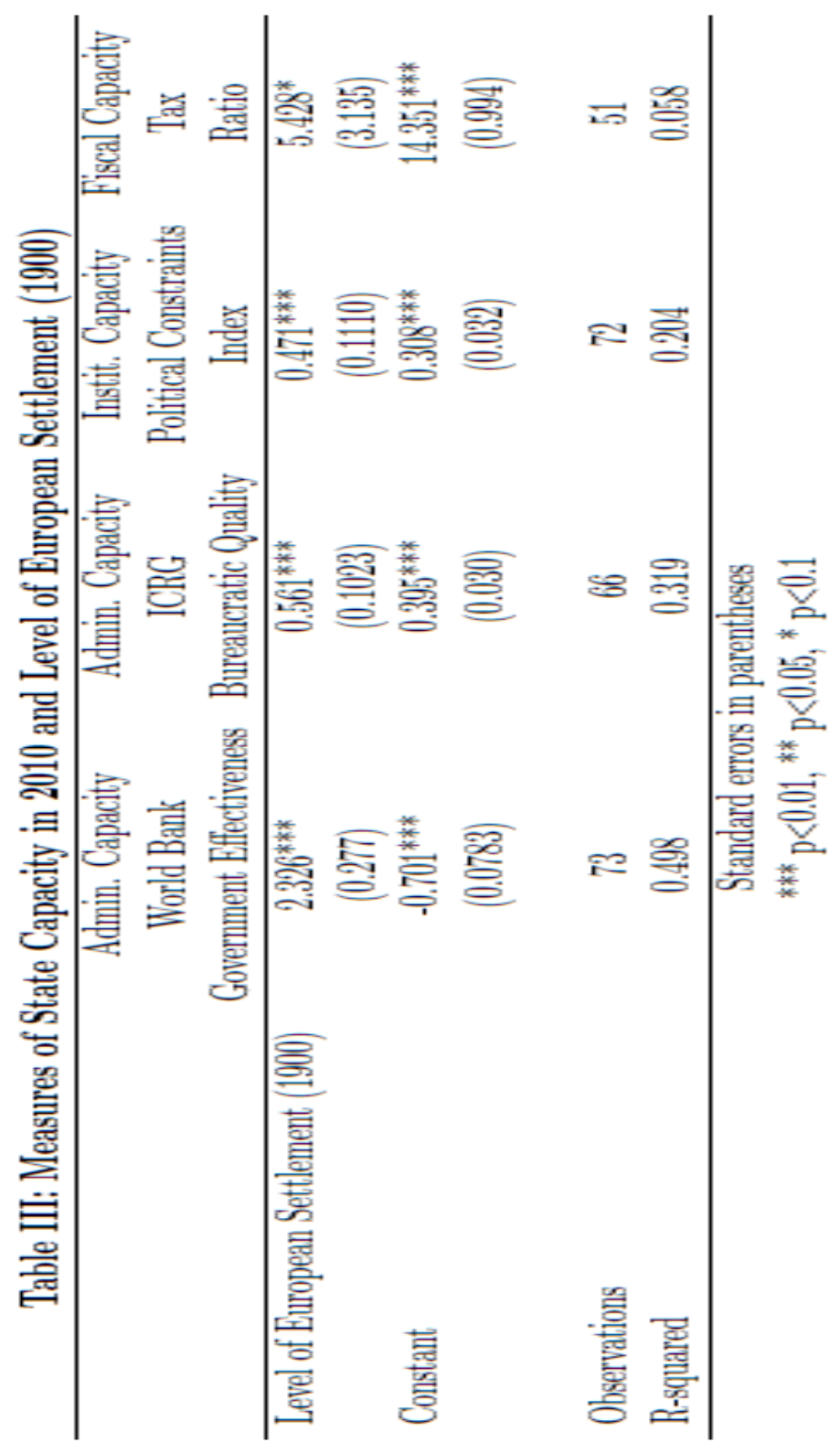


Table 3.4: Measures of State Capacity in 2010 and Settler Mortality

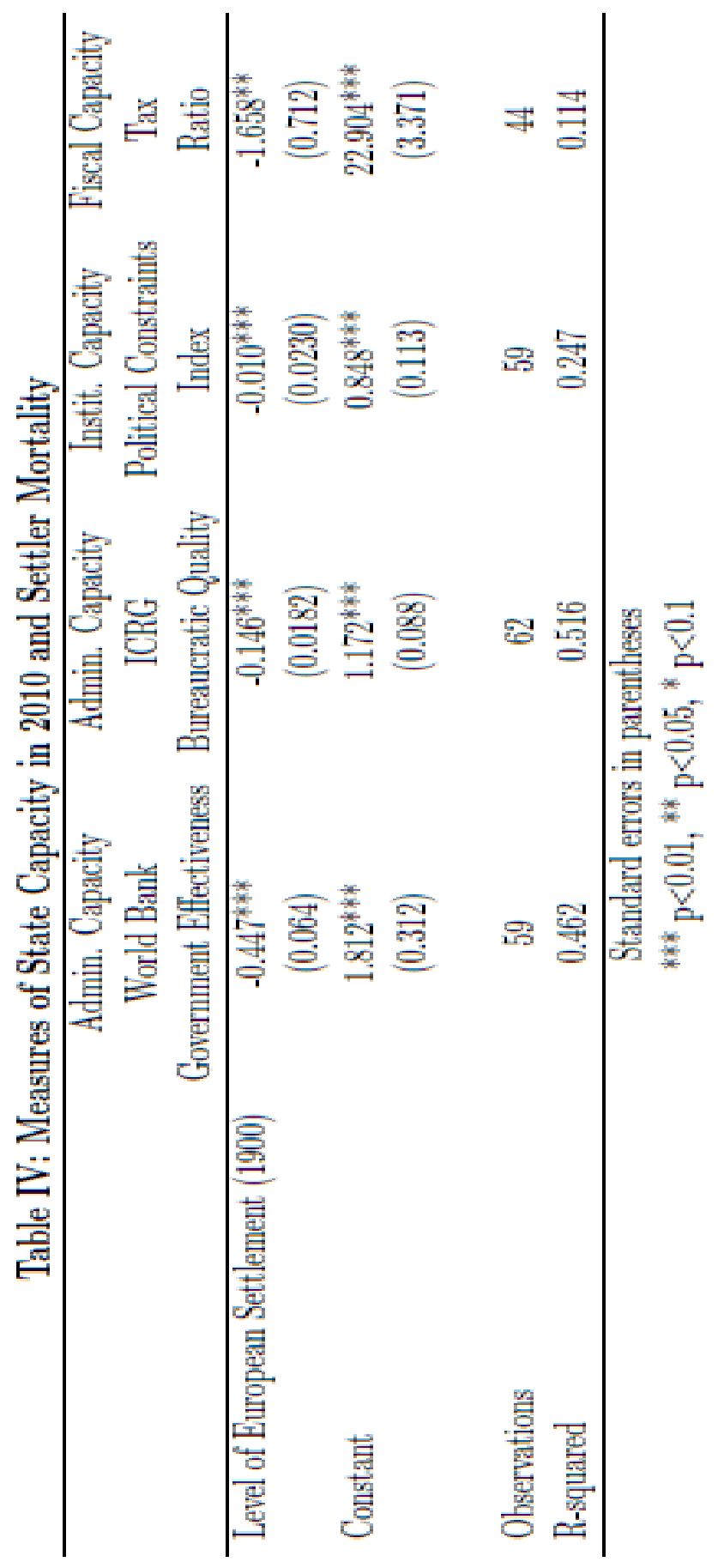


Table 3.5: Measures of State Capacity in 2010 with Huber Weights

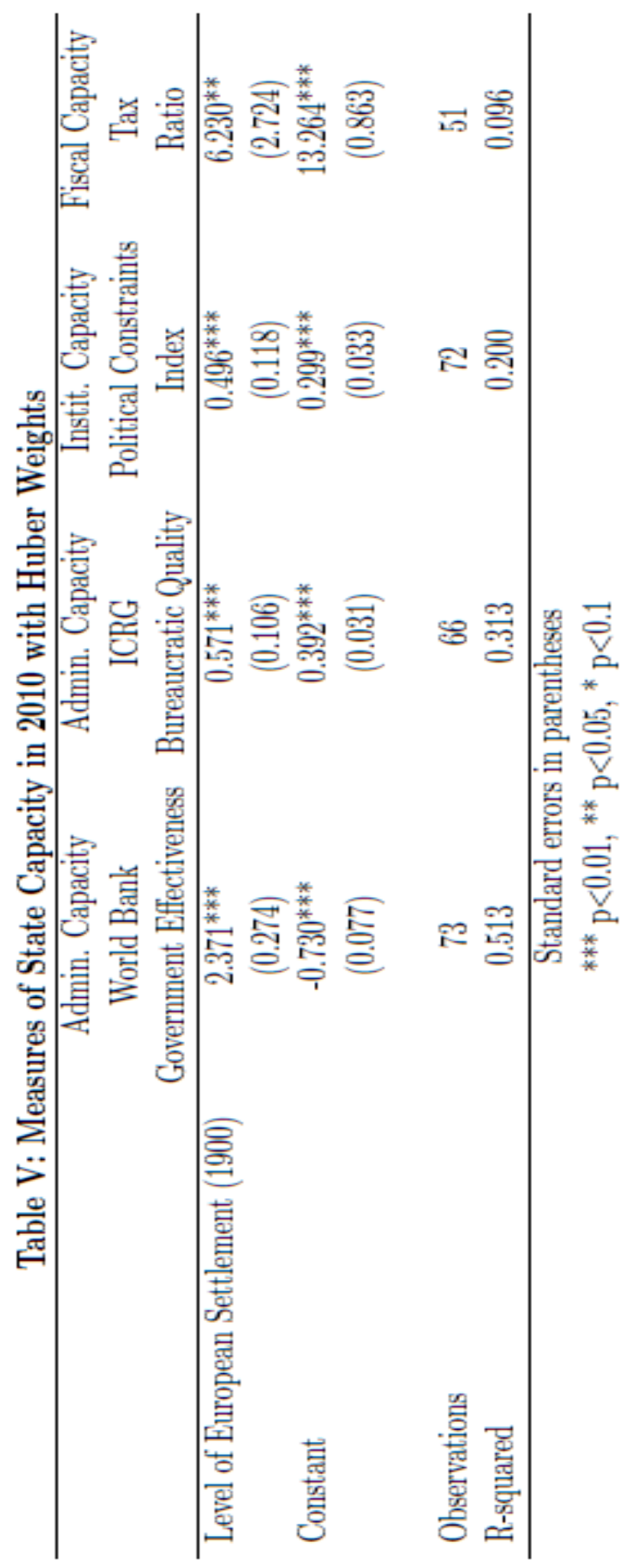


Figure 3.1 0-1: Level of European Settlement and Government Effectiveness

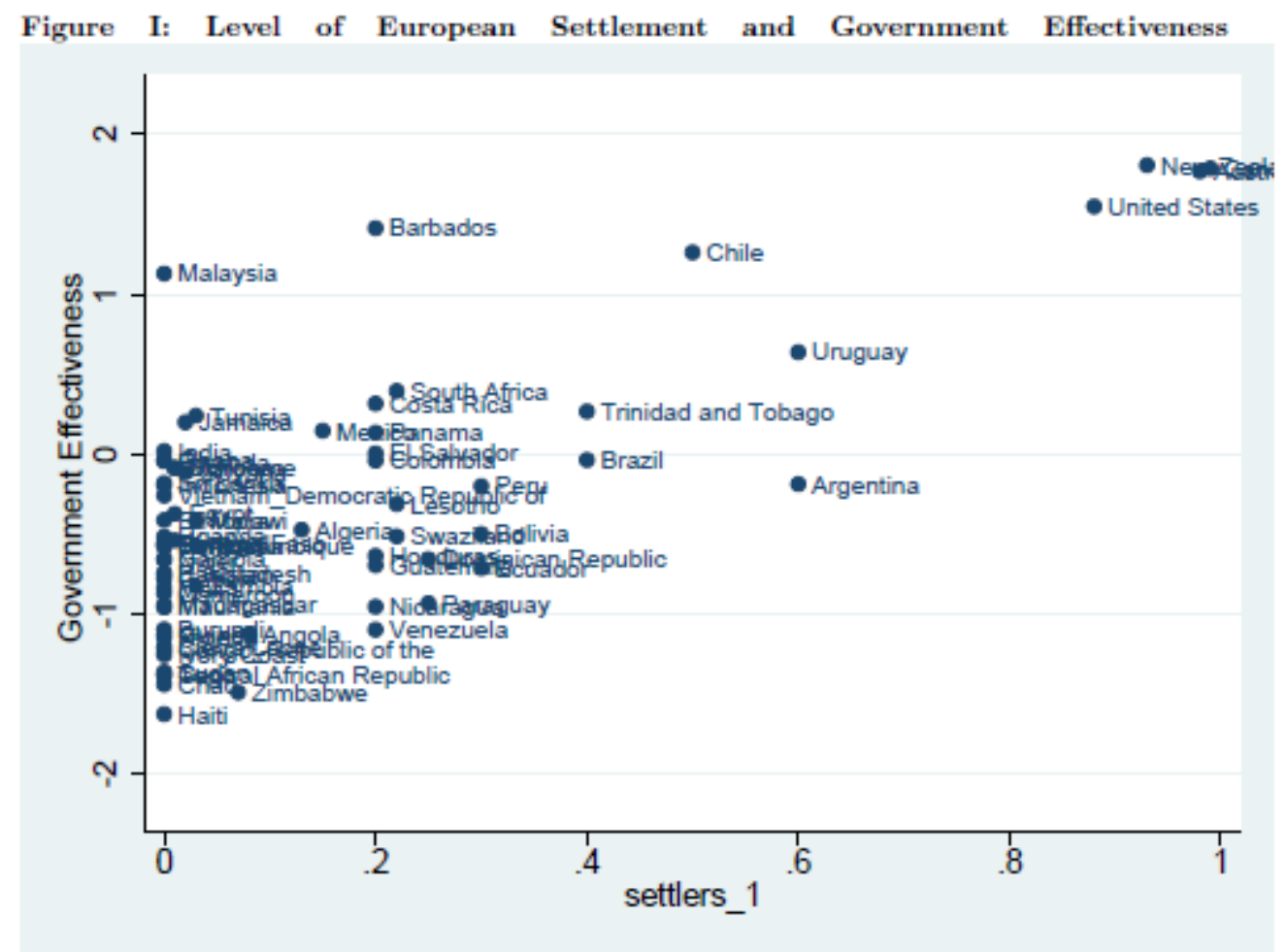




\section{Appendix: Variable Descriptions}

Figure 3.2: Variable Descriptions

\begin{tabular}{|c|c|}
\hline Percentage of European Settlers in 1900 & The percentage of the population of \\
\hline Constraint on Executive in 1900 & $\begin{array}{l}\text { European descent, from } 0 \text { to } 100 \text {. } \\
\text { A seven category scale from } 1 \text { to } 7 \text {, with higher } \\
\text { values indicating more constraints on the executive, } \\
\text { and lower values indicating few limits on authority. }\end{array}$ \\
\hline Constraint on Executive in 1st Year & A seven category scale from 1 to 7 , with higher \\
\hline Post-Independence & $\begin{array}{l}\text { values indicating more constraints on the executive, } \\
\text { and lower values indicating few limits on authority. }\end{array}$ \\
\hline Log Settler Mortality & $\begin{array}{l}\text { The logged level of European settler mortality, with } \\
\text { a minimum of .9361 and maximum of } 7.9861 \text {. }\end{array}$ \\
\hline Average Protection against & The risk of expropriation of private foreign investment \\
\hline Expropriation & from government, on a scale from 0 to 10. \\
\hline Latitude & $\begin{array}{l}\text { The absolute distance of the country from the equator } \\
\text { rescaled on a scale from } 0 \text { to } 1 .\end{array}$ \\
\hline Years Independent: 1995 minus & The number of years a country has been \\
\hline First Year & independent in 1995 minus the first year. \\
\hline Democracy in 1900 & $\begin{array}{c}\text { An } 11 \text { category scale from } 0 \text { to } 10 \text {, with higher } \\
\text { values indicating more democracy. }\end{array}$ \\
\hline
\end{tabular}




\section{Chapter IV: COLONIAL EDUCATIONAL ATTAINMENT AND CONTEMPORARY OUTPUTS IN STATE CAPACITY}

To date, the political economy literature has assessed how the level of European settlement influenced institutional quality in the colonies and contributed to divergent outcomes in economic development. There is considerable evidence that higher levels of European settlement had an overall positive effect on economic development through the transmission of institutions and property rights. While these studies have uncovered the importance of European settlement for transmitting liberal institutional traditions at the macro-level, what is missing in analyses of colonial legacy analyses is an explicit examination of an additional mechanism that may also account for the transmission of these institutions to the colonized population. another mechanism—education.

At the core of state building is the near necessity of a synergy between 'the state' and 'society', in which civil society has the ability to constrain state capabilities or legitimize and reinforce the state's authority (Migdal 1988). Central to this study is the argument that education serves as a vehicle for socializing the population into adopting norms and laws created by the state, education contributes to state building by encouraging the population to enter the bureaucracy. The inclusion of the colonized population in human capital creating institutions aids the transmission of liberal institutions, and ultimately contributes to the effect of colonial legacy on contemporary state capacity. In this chapter, I analyze the effect of colonial education policies as leading to institutions that built human capital and thereby shaped colonized populations' ability to govern after independence. I empirically assess the relationship between 
educational attainment levels in 1900 and the 2010 levels of state capacity for former colonies.

I find that even when controlling for the level of European settlement, and the expanse of the state both prior to and during the colonial enterprise, the level of educational attainment has an independent effect on contemporary state capacity. In the first section of this chapter, I revisit the theory behind colonial inclusivity, and present the hypothesis to be tested. In the second half of this chapter, I provide an explanation of the indicators employed here, and enter an empirical investigation of the effects of colonial educational attainment levels on three prominent indicators of state capacity in the political economy literature. In the final section of this paper, I conclude with a discussion of the results.

\subsection{The Argument}

My core argument is that education and the development of human capital is instrumental to state building. Education is one of several mechanisms for state building, a point I return to in the conclusion. There are a lot of ways to build a state; education is one of these and it is this mechanism that I explore here. Additionally, for simplicity I assume that education is a homogenous practice, without getting into the particulars of the variation in educational policy across space within a territory.

Education serves as the vehicle for incorporating the colonized population into the state, and preparing them to enter the meritocratic, Weberian bureaucracy (Evans and Rauch 1999). These inclusive policies were most likely to occur when the colonizing state had a liberal domestic paradigm. By the turn of the $20^{\text {th }}$ century, much of Western 
Europe had adopted constitutional liberalism at the behest of British hegemony (Parry 2006). This adoption of liberalism began to surface in their policy making and perceived moral obligation towards their colonial 'countrymen'. By the middle of the $19^{\text {th }}$ century, many of the European colonial powers began investing in the colonized population, such as the French in Benin (Wantchekon, Klasnja, and Novta 2014), the British in India and Malaya (Whitehead 1981), and the Dutch in the East Indies (Penders 1968). This coincided with their desire for territorial and operational expansion. Granted, this varied, and this shift did not occur for all colonial territories. ${ }^{22}$ Nevertheless, in contexts where this shift did occur, this investment in the human capital of subjugated populations was important for their ability to serve in the central bureaucracy and engage in the nonagricultural sector.

European investment in human capital for the colonized population had long-term ramifications for the development and state building capabilities of the population postindependence. Although the colonial enterprise was characteristically corrosive of preexisting structures, including those that were central to human development (Banerjee \& Prasad 2008) served as a means of developing the colonized population in the presence of otherwise extractive foreign occupiers. The corollary is that not providing colonial populations with adequate education more than likely meant their exclusion from the central bureaucracy, which contributed to ineffective institutional transmission and stagnation post-independence.

\footnotetext{
${ }^{22}$ Many of the European colonial powers did not view colonial populations equally. Territories that experienced educational expansion was driven by European racial perceptions. Colonies in Asia and the Americas-barring much of the Caribbean-experienced educational expansion, while much of Africa was left untouched by the sudden ideological shifts in Europe.
} 
The percentage of the colonized population that was given access to education and subsequent educational attainment levels contributed to either nurturing or harming institutional diffusion post-independence. The skills necessary to either maintain or develop effective institutions requires skilled labor and an educated class (Glaeser et al. 2004; Green 1990; 2013; Lipset 1959). This is supported by Green (1990), who argues that skilled labor that stems from higher levels of human capital (i.e. educational attainment levels) within a population is essential for effective state building. In the context of colonialism and liberal institutional transmission, granting access to education was crucial to the survival and the quality of the survival of colonial institutions. During and after independence, higher educational attainment amongst the non-European population had ramifications for the quality of the bureaucracy and strength of the nonagricultural sector. This line of reasoning is also supported by the analysis of Glaeser et al. (2004), who find that human capital measured as total years of schooling is a better explanation of economic growth than prominent measures of institutions. Like Glaeser et al. (2004), I shift my attention away from a state institution explanation of development to an education based explanation of state development. ${ }^{23}$

This argument suggests that the expansion and extension of education to nonEuropean populations at all levels influenced the quality of the bureaucracy and subsequently contemporary outputs in state capacity. I will assess the effect of colonial educational attainment using the following:

\footnotetext{
${ }^{23}$ Note, the explanation put forth here does not assume that absent the colonial enterprise these societies would not have advanced, but rather that colonialism was so disruptive to pre-existing sociopolitical orders that it left a legacy on the fragmented societal and political structures in its wake.
} 
Hypothesis: All else being equal, higher levels of educational attainment among the colonized population contribute to higher levels of contemporary state capacity.

\subsubsection{Government Effectiveness}

To assess the effect of colonial educational attainment on state capacity and to capture its multifaceted nature, I opt to operationalize state capacity in three different ways. These three ways of operationalizing the concept are informed by commonly used variables across the literature. First, I capture what is commonly employed in the public administration literature as administrative capacity, which is the ability of the state to legislate and implement policy without intrusion from an external entity. This is measured by utilizing the World Bank's government effectiveness (Kaufmann, Kraay, and Mastruzzi 2011). This measure of state capacity is holistic, in that it captures the quality of the bureaucracy, institutional effectiveness, and the quality of public services. Explicitly from its progenitors, government effectiveness is an index that:

$[\ldots]$ captures perceptions of the quality of public services, the quality of the civil service, and the degree of its independence from political pressures, the quality of policy formulation and implementation, and the credibility of the government's commitment to such policies. (Kaufmann, Kraay, and Mastruzzi 2011).

The government effectiveness index ranges from -2.5 to 2.5 , with negative values indicating poor governance, whereas positive values indicate good governance. The index is a composite of scores from various sources, including the bureaucratic quality indicator that I assess separately (PRS Group 2016). 


\subsubsection{Bureaucratic Quality}

The second measure of state capacity that I employ is bureaucratic quality (PRS Group 2016), which is an index on a scale from 0 to 4 , with high scores given to countries with bureaucracies that have the expertise and strength to govern without interruptions in government services or dramatic changes in policy (Howell 2011, 7). Even though there is some overlap between the two measures of administrative capacity employed here (e.g. World Bank government effectiveness and ICRG bureaucratic quality), these two indices have been used differently in the literature. Bureaucratic quality is prominent in the good governance, economic development, foreign aid, and conflict literature (Chong and Calderon 2000; Hendrix 2010; Knack 1999; Knack and Rahman 2007; Lambsdorff 2003; La Porta, Lopez de Silane, Shleifer, and Vishny 1996; Rauch and Evans 2000; Selaya and Thiele 2012; Van de Walle 2005), while government effectiveness is predominantly used in the literatures on governance, economic development and the comparative politics literature on democracy (Guisan 2009; Globerman and Shapiro 2002; 2003; Kapoor and Ravi 2012; Knack 2002; Lee and Whitford 2009; Magalhães 2014). This warrants assessing both for added robustness.

\subsubsection{Tax Ratio}

Lastly, the literature has operationalized state capacity as the fiscal capacity of the state. I utilize the World Bank's tax ratio, which is the tax revenue as a percentage of GDP (World Bank 2016), utilized by Thies (2010). The values for this variable are a percentage of the GDP for each country, from $[0,100]$. For example, the total tax revenue collected by Malaysia's central government in 2010 was $14.3 \%$ of their GDP, whereas 
the total tax revenue collected by Indonesia's central government in 2010 was $10.9 \%$ of their GDP.

\subsubsection{Colonial Educational Attainment}

I measure level of colonial educational attainment as an estimation of the total years of schooling of the population aged 15-64 (Lee and Lee 2016). Lee and Lee (2016) create the total years of schooling indicator from school enrollment estimates derived from various sources, such as the League of Nations' efforts to collect country statistics, UNESCO, and a host of compendia (Benavot and Riddle 1988; Mitchell 2003a, b, c; Lindert 2004; Banks and Wilson 2013). Total years of schooling is comprised of data from 1870-1920, and historical enrollment ratios from 1820-1945. Lee and Lee (2016) combine this information with census data ${ }^{24}$ from a later period that has information on educational attainment by age (Lee and Lee 2016, 160). Additionally, Lee and Lee (2016) use backwards extrapolation from census data in 1950 to estimate pre-1950 educational attainment levels. ${ }^{25}$

Following much of the colonialism literature (e.g., Acemoglu, Johnson, and Robinson 2001; Banerjee and Iyer 2005; Feyrer and Sacerdote 2009; Sokoloff and Engerman 2000), the dataset is cross-sectional; educational attainment observations are from 1900. The data is somewhat arbitrary, but it lies within the height of imperialism (1800-1914) and maximizes data availability, including a sample of 56 former colonies,

\footnotetext{
${ }^{24}$ UNESCO's Statistical Yearbook (various years) contains the actual enrollment ratios.

${ }^{25}$ Naturally, backwards extrapolation is not the most ideal coding scheme for this indicator. In order to ascertain that the 1900 statistics are unique from the 1950 level data, I correlated total years of schooling in 1900 and 1950 and found that they are statistically distinct. Currently, this indicator is the best-known recent estimate of historical educational attainment levels, which has been cited by 39 published articles since its publication but has yet to be utilized in political science research.
} 
of various colonial origins and administrative traditions (e.g. British, French, Dutch, Spanish, Belgian, and Portuguese). Also, the selection of the year 1900 is motivated by the fact that this date precedes the extensive expansion of education to the colonized population, in response to economic conditions and the World Wars in Europe. I provide further justification for the selection of 1900 in Chapter V. Table 1 contains all the explanatory variables and the dependent variable, their data sources, and their descriptive statistics.

[Table 1 about here]

\subsubsection{Control Variables}

I control for possible alternative explanations such as the level of European settlement, pre-colonial and colonial statehood, colonial identity (e.g. British or French), and logged GDP per capita. The level of European settlement is derived from Acemoglu, Johnson, and Robinson (2001), who operationalize the level of European settlement as the "fraction of the population of European descent in 1900". This data is extracted using the statistics from McEvedy and Jones (1975) and Curtin et al. (1995).

In order to control for the possibility that the extent of the colonial state may have an effect on colonial education attainment levels, I utilize the level of statehood which is an estimation of early state capacity derived from the State Antiquity Index (version 3) created by Bockstette and Putterman (2007). ${ }^{26}$ Potentially, early statehood limited the

\footnotetext{
${ }^{26}$ The index is creates using the borders of current countries to identify observations, and comprised of scores for each 39 half centuries from year 1 to 1950 by answering three questions. "a) Is there a government above the tribal/chiefdom level? ( 1 if yes, 0.75 if chiefdom, 0 if tribe); b) Is the government locally based? ( 1 if yes, 0.75 if there is a local government with substantial foreign oversight, 0.5 if foreign based); c) How much of the present-day country's territory was ruled by the historical government? ( 1 if more than 50\%; 0.75 if between $25 \%$ and 50\%, 0.5 if between $10 \%$ and $25 \%, 0.3$ if less than $10 \%$ ) (Hariri
} 
options available to settlers upon their arrival. Pre-colonial societies that had more extensive states were more limiting to settlers. I utilize estimates for the 1451-1500 half century to create an indicator for statehood in 1500 (e.g. pre-colonial statehood), henceforth called state capacity in 1500 . One could argue that pre-colonial state capacity has more of an influence on the contemporary indicators of state capacity than education. Thus, I control for that here, and explore it more directly in an extension of this analysis. I also use estimates for the 1801-1850 half century to create an indicator for statehood in 1850 (colonial state capacity). Higher values of statehood indicate that the historical state had a significant government beyond a chiefdom or tribe, was locally based with little to no foreign oversight, and held a substantial portion of the territory ruled by the government.

Additionally, I assess the extent to which the identity of the colonial power matters for the state capacity of former colonies. I measure this using dummy variables for the British colonial identity, which measures whether or not an observation is a British colony, with " 1 " being yes and "0" being no. I do not explicitly control for colonies that were colonized by the Spanish, Portuguese, or Dutch, given that the main argument for why this matters emphasized the differences between the British and French (La Porta et al. 1998, 1999). Thus, this is a fixed effects model of colonial identity. Finally, there may be a link between economic development and geographic location, and the capacity of the state. I control for this using logged GDP per capita from the World Bank estimates for 2010, and the United Nations Statistics Division (2013).

$2012,475) . "$ The scores from each of the questions is multiplied for the each $1 / 2$ century and the final score for the index is computed as a summation of the discounted value of the scores for the 39 half centuries. For more information, see Bockstette and Putterman (2007). 


\subsection{Preliminary Analysis}

I begin my empirical investigation by examining the relationship between education attainment levels and government effectiveness. As a preliminary assessment, I explore the correlation between educational attainment in 1900 and state capacity in 2010, which is depicted in Table 2. The correlation between educational attainment and government effectiveness is $(0.74 / 1.00)$, providing preliminary evidence in support of my hypothesis. Figure 1 demonstrates visually the correlation between these two indicators, confirming that educational attainment is associated with subsequent state capacity.

[Table 2 about here]

[Figure 1 about here]

\subsection{Outliers: Neo-Europes}

Crosby (1986) and Fails and Krieckhaus (2010) argue that Neo-Europes (i.e. U.S., Canada, New Zealand, and Australia) are different than other colonies because there was a high level of European settlement due to the eradication of the pre-existing societies and populations in those territories. As a result, this created a blank slate for state building. In these colonies, education levels were much higher. The inclusion of these countries in the sample could affect the estimates in both the correlation of these two indicators, and the regression analysis in the next section. It is therefore important to ensure that the results are not driven by these outliers. Figure 2 demonstrates that if anything, the relationship holds even more strongly outside of the Neo-Europes.

[Figure 2 about here] 
Table 4 includes estimates of the effect of colonial educational attainment on contemporary state capacity, including the Neo-Europes. Neo-Europes are excluded from Tables 5-8; unlike the Acemoglu, Johnson, and Robinson (2001) story in which the positive results disappear once the Neo-Europes are excluded from the model (Fails and Krieckhaus 2010), the results here remain strong even after they are excluded. The appendix contains tables with the same models from Tables 5-7, including the NeoEuropes for comparison. As seen there, the effect of education is clear regardless of whether one includes or excludes the Neo-Europes. Given that the results without outliers are more conservative, I exclude those in the primary tables.

\subsection{Does Colonial Education Attainment Merely Reflect Prior State Capacity?}

Before moving into the results section, it is important to address a classic problem in political science empirical assessments, which is the potential for reverse causation (Przeworski 2004; 2009). My core argument is that colonial education policies are a predictor of contemporary state capacity in former colonies. A potential problem is that state capacity before or during the colonial period may explain colonial education policy, and thus education is a consequence of state capacity rather than a cause. This reverse causality objection stems from the possibility that early statehood or state capacity determined what options were available to colonists. A strong pre-existing state apparatus might lead to robust educational policies.

In point of fact, empirically the relationship between pre-colonial state capacity and educational attainment indicates the opposite of this claim. This finding is supported by the preliminary empirical evidence provided by Table 3 , which contains model 1-4. I 
assess the effect of pre-colonial and colonial state capacity — using the best data available on early state capacity ${ }^{27}$ —on educational attainment in 1900 and on the World Bank's government effectiveness indicator, independently. Contrary to the notion that effective states had high educational attainment, thereby leading to even more effective states, in point of fact it was the less effective states that had more educational attainment.

[Table 3 about here]

\subsection{OLS Results}

I begin the main section of this empirical assessment with strong evidence in support of my hypothesis. The results reported here suggest that colonial education policies that contributed to higher levels of educational attainment had a positive influence on the first measure of state capacity - the level of government effectiveness. In model 5 of Table 4, I estimate the influence of educational attainment levels, controlling only for level of European settlement. A key aspect of the political economy narrative emphasizes the influence of European settlement on institutional development. Yet, educational attainment levels are statistically significant and robust to the inclusion of this prominent indicator in the literature.

[Table 4 about here]

I argued above that state capacity is not a product of the pre-historical state, and in models 6-7 on Table 4, I explore pre-colonial state capacity (in 1500) and colonial state capacity (in 1850). Model 6 includes state capacity in 1500; while educational attainment remains significant and the coefficient is relatively unchanged $(0.34, p<0.01)$, the

\footnotetext{
27 I explain this operationalization of early state capacity in greater detail in the empirical section of this assessment.
} 
coefficient for level of European settlement increases along with its significance level $(1.11, \mathrm{p}<0.05)$. State capacity in 1500 , however, does not appear to have an independent effect on contemporary government effectiveness.

Since the same reverse causation argument could apply to colonial state capacity circa 1850, in model 7, I estimate the strength of this relationship and find that there is an effect of colonial state capacity on government effectiveness, albeit at the $90^{\text {th }}$ percentile $(\mathrm{p}<0.10)$, with an increase in colonial statehood contributing to a decrease in government effectiveness of 0.01 . This can be explained by the goals of these regimes, which were largely to extract as much as possible. Educational attainment levels still matter at a lower significance level, as does level of European settlement (1.4, $\mathrm{p}<0.05)$. A plot of the relationship between government effectiveness and educational attainment is provided below, which also graphically depicts where each country falls on the line.

[Figure 2 about here]

In the next set of models (8-10) in Table 5, I assess the relationship between government effectiveness and educational attainment levels in former colonies, excluding the Neo-Europes (United States, Canada, Australia, and New Zealand). ${ }^{28}$ In model 8, I find that educational attainment levels seem to have a more pronounced effect on government effectiveness, with an increase in total years of schooling contributing to an increase in government effectiveness of $0.58(\mathrm{p}<0.01)$. In this estimation, once the NeoEuropes are excluded from the model, the level of European settlement no longer matters. Prior to this analysis it would seem that high levels of European settlement would have

\footnotetext{
${ }^{28}$ See the discussion on page 16 about the difference between the Neo-Europes and the rest of the former colonies, as articulated by Fails and Krieckhaus (2010).
} 
long term ramifications for government effectiveness. However, colonies without large settlements akin to the Neo-Europes did not experience the same level of effect. This also provides evidence that the results in Table 4 are not driven by countries with high European settlement. In model 9 and 10, educational attainment levels in 1900 remain significant, even after including state capacity in $1500(0.008, \mathrm{p}<0.10)$ and 1850 .

[Table 5 about here]

Now, I turn my attention to the influence of educational attainment on my second measure of state capacity - bureaucratic quality. In Table 6, models 11-13, I find that educational attainment levels in 1900 influences bureaucratic quality in 2010, with varying levels of significance, and with level of European settlement remaining insignificant across the four models in Table 6. In model 11, an increase in colonial educational attainment levels leads to a 0.17 increase in bureaucratic quality $(\mathrm{p}<0.05)$. Similarly, in model 12, an increase in educational attainment levels leads to an increase in bureaucratic quality. Distinct from the government effectiveness models, there is a significant relationship between pre-colonial state capacity in $1500(0.005, \mathrm{p}<0.01)$ and bureaucratic quality, as one would expect. In model 13, the effect of educational attainment in 1900 remains, while state capacity in 1850 is statistically insignificant for bureaucratic quality. In sum, these results suggest that, like government effectiveness, the relationship between educational attainment levels during colonialism has a significant influence on post-colonial governance, when examining two prominent indicators for measuring state capacity.

[Table 6 about here] 
On table 7, I turn my attention to assessing the sensitivity of my third measure of state capacity - the tax ratio (fiscal capacity) in former colonies - to colonial levels of educational attainment. Across model 14-16, I find that educational attainment levels matter for the fiscal capacity of former colonies, even when controlling for pre- and colonial state capacity, as well as level of European settlement. In model 14 and 15, the level of educational attainment for any given colony increases the tax ratio by 4.9 $(\mathrm{p}<0.05)$ and $4.62(\mathrm{p}<0.05)$ respectively. This is a significant increase given that the minimum and maximum values for the tax ratio is 7.83 and 34.40 . In model 16 , the effect of the level of educational attainment on the tax ratio is slightly smaller. State capacity in 1850 is also significant in the expected direction. This is expected because a large colonial state may lead to an extractive state in the worse way, which could contribute to effective predatory states after independence.

[Table 7 about here]

\subsection{Sensitivity Analysis}

A prominent alternative explanation in the literature regarding colonial legacy and development relates to the difference created by colonial identity. For some scholars, the British were unique in their creation of complex bureaucratic institutions in their colonies, even though all colonies had institutions of some kind or other. In order to assess the robustness of the explanation explored here to the influence of colonial identity, I estimate the relationship between the level of educational attainment on all measures of state capacity, controlling for British colonialism. In models 17-19 in Table 8, I examine this relationship while also controlling for colonial identity (i.e. British or 
not British). In model 17, I find evidence that colonial educational attainment remains significant for post-colonial fiscal capacity (tax ratio), controlling for level of European settlement, statehood in 1500, and British colonialism. In model 18, I find that educational attainment has a significant influence on government effectiveness, while the level of European settlement, state capacity in 1500, and British colonialism does as well. In model 19, I assess the influence of colonial educational attainment levels on bureaucratic quality, and find evidence that it is robust, even with the inclusion of British colonialism. These results affirm the importance of educational attainment for the bureaucracy, as well as provides further evidence for past studies that argue that the level of settlement and British colonialism matter for bureaucratic quality. What is interesting is that British colonialism in and of itself does not have an independent effect on tax as a percentage of GDP (fiscal capacity), even though scholars have previously argued that British colonialism was especially good for post-colonial economies writ large.

[Table 8 about here]

Finally, scholars often contemplate the relevance of geographic location for economic development (Gallup, Sachs, and Mellinger 1999; Krugman 1997; Rodrik, Subramanian, and Trebbi 2004). Potentially, geographic location (Coppedge et al. 2015: 267) and economic development proxied by logged GDP per capita are an alternative explanation for contemporary state capacity. These two indicators have been empirically controlled for in previous colonial studies. I assess the influence of colonial educational attainment on contemporary state capacity, while controlling for the geographic location and logged GDP per capita of the countries in the sample. I find that educational attainment in 1900 still remains significant for contemporary state capacity, even when 
geography is included in the model. Geography has no effect on contemporary levels of state capacity, while logged GDP per capita has an expected relationship with contemporary capacity. Even though logged GDP per capita has an effect on contemporary state capacity $(\mathrm{p}<0.01)$, educational attainment levels in 1900 remains impervious to its inclusion in model 22.

[Table 9 about here]

\subsection{Is 1900 merely $1950 ?$}

A fair critique of this analysis is that educational attainment in 1950, after independence, is most relevant for contemporary state capacity in all forms. Along with this critique, there is also a counter-argument that educational attainment levels in 1950 are the same as 1900, and thus drawing a conclusion from educational attainment levels from over 100 years ago is inappropriate. Arguably, educational attainment levels in 1950 were predicated on educational attainments levels at the turn of the twentieth century, at the height of the colonial era. We can infer from the correlation in Table 10 that education policies in former colonies were path dependent, and that decisions made by colonists affected post-colonial education policy decisions. Moreover, post-colonial education policy decisions as a product of colonial education policies affected education policy decisions going into the $21^{\text {st }}$ century. Correlating educational attainment levels in 1900 and 1950, we get the following results in an OLS estimation:

[Table 10 about here]

The model in Table 10, with educational attainment in 1900 regressed on educational attainment in 1950, demonstrates that educational attainment in 1900 is a strong predictor 
of educational attainment levels in the middle of the twentieth century, which is postindependence for a large percentage of countries in the sample of 60 former colonies. This is further demonstrated by the scatterplot below which suggests that there is a relationship and that there is some variation between the two timepoints.

[Figure III about here ]

\subsection{Summary}

In the research on the significance of colonialism for contemporary outputs in economic development, much of the emphasis has been placed on the importance of the level of European settlement for development or economic stagnation. In this chapter, I delve deeper into colonial inclusivity by focusing on colonial education and its effect on state capacity across former colonies. This particular chapter is distinct from the rest of the literature in its focus on colonial education policy outputs (educational attainment levels) and their legacy and impact for contemporary state capacity.

Here, I assessed the relationship between levels of educational attainment in 1900 and contemporary state capacity for 56 former colonies in 2010. I examined this relationship in terms of three prominent indicators of state capacity-government effectiveness, bureaucratic quality, and tax ratio. I find that colonies' education attainment levels at the turn of the $20^{\text {th }}$ century are still relevant for explaining variation in their state capacity in 2010. Moreover, these results are not the artifacts of pre-colonial history; this finding still holds when controlling for levels of settlement, pre-colonial and colonial state capacity, geographic location, and GDP per capita as a measure of economic development. Decisions during the colonial era regarding the education 
apparatus, which is key to developing the human capital of a population, had long term ramifications for state capacity.

This chapter moves us closer to understanding which factors are important for state capacity in the long run by shifting state capacity from being an explanatory variable to a dependent variable. The results of this chapter have implications for more than just the determinants of state capacity, but also speak to the literature on human capital and institutional development. Moreover, this study provides evidence for the importance of education in and of itself for institutional development and maintenance.

\subsection{Tables and Figures}

Table 4.1: Descriptive Statistics

\begin{tabular}{|c|c|c|c|c|}
\hline Variable & Variable Type & Min & Max & Source \\
\hline State Capacity & $\begin{array}{l}\text { Dependent } \\
\text { Variable }\end{array}$ & $\begin{array}{l}-1.65 \\
0 \\
7.83\end{array}$ & $\begin{array}{l}2.25 \\
1 \\
34.30\end{array}$ & $\begin{array}{l}\text { WB Government } \\
\text { Effectiveness; } \\
\text { ICRG Bureaucratic } \\
\text { Quality; } \\
\text { World Bank Tax } \\
\text { Ratio }\end{array}$ \\
\hline $\begin{array}{l}\text { Educational } \\
\text { Attainment }\end{array}$ & $\begin{array}{l}\text { Independent } \\
\text { Variable }\end{array}$ & 0.005 & 5.7 & $\begin{array}{l}\text { Total Years of } \\
\text { Schooling in } 1900 \\
\text { of Population aged } \\
\text { 15-64 (Lee and Lee } \\
\text { 2016) }\end{array}$ \\
\hline $\begin{array}{l}\text { Economic } \\
\text { Development }\end{array}$ & $\begin{array}{l}\text { Control } \\
\text { Variable }\end{array}$ & 6.25 & 10.05 & $\begin{array}{l}\text { World Bank Logged } \\
\text { GDP Per Capita }\end{array}$ \\
\hline $\begin{array}{l}\text { Level of } \\
\text { European } \\
\text { Settlement }\end{array}$ & $\begin{array}{l}\text { Control } \\
\text { Variable }\end{array}$ & 0 & 0.6 & $\begin{array}{l}\text { Acemoglu, Johnson, } \\
\text { and Robinson } \\
\text { (2001) }\end{array}$ \\
\hline $\begin{array}{l}\text { Statehood in } \\
\text { 1500; } \\
\text { Statehood in } \\
1850\end{array}$ & $\begin{array}{l}\text { Control } \\
\text { Variable }\end{array}$ & $\begin{array}{l}0 \\
0\end{array}$ & $\begin{array}{l}50 \\
50\end{array}$ & $\begin{array}{l}\text { Bockstette and } \\
\text { Putterman (2007) }\end{array}$ \\
\hline $\begin{array}{l}\text { Educational } \\
\text { Attainment in } \\
1950\end{array}$ & $\begin{array}{l}\text { Control } \\
\text { Variable }\end{array}$ & 0.024 & 8.84 & $\begin{array}{l}\text { Total Years of } \\
\text { Schooling (Barro } \\
\text { and Lee 2013) }\end{array}$ \\
\hline
\end{tabular}


Table 4.2: Correlations

Variables

Correlation

Government Effectiveness

$0.74 / 1.00(0.55 / 1.00)$ and Educational Attainment

* Note the number in parenthesis is the correlation squared.

Figure 4.1: Two-way scatterplot of Total Years of Schooling (ages 15-64) and World Bank Government Effectiveness

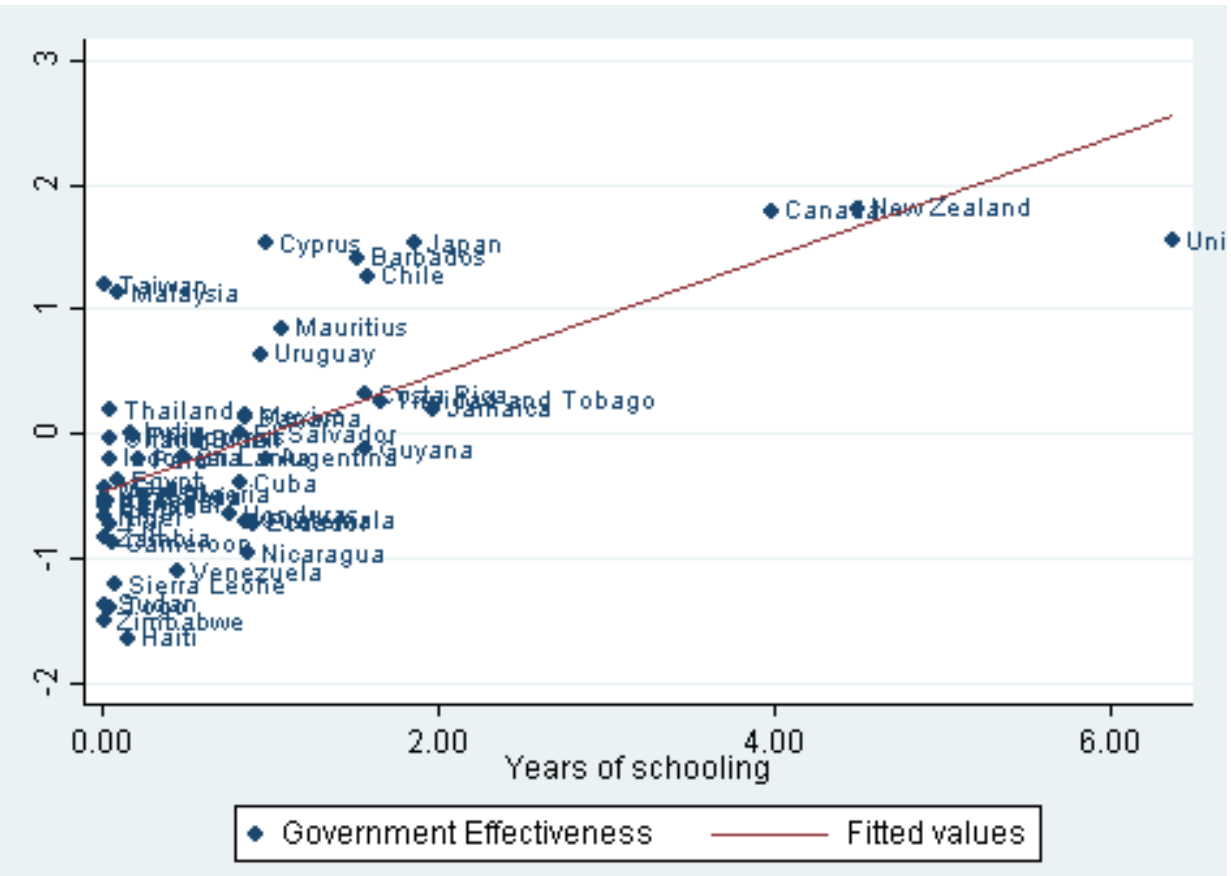


Figure 4.2: Two-way scatterplot of Total Years of Schooling (ages 15-64) and World Bank Government Effectiveness (w/o U.S., Canada, New Zealand, and Australia)

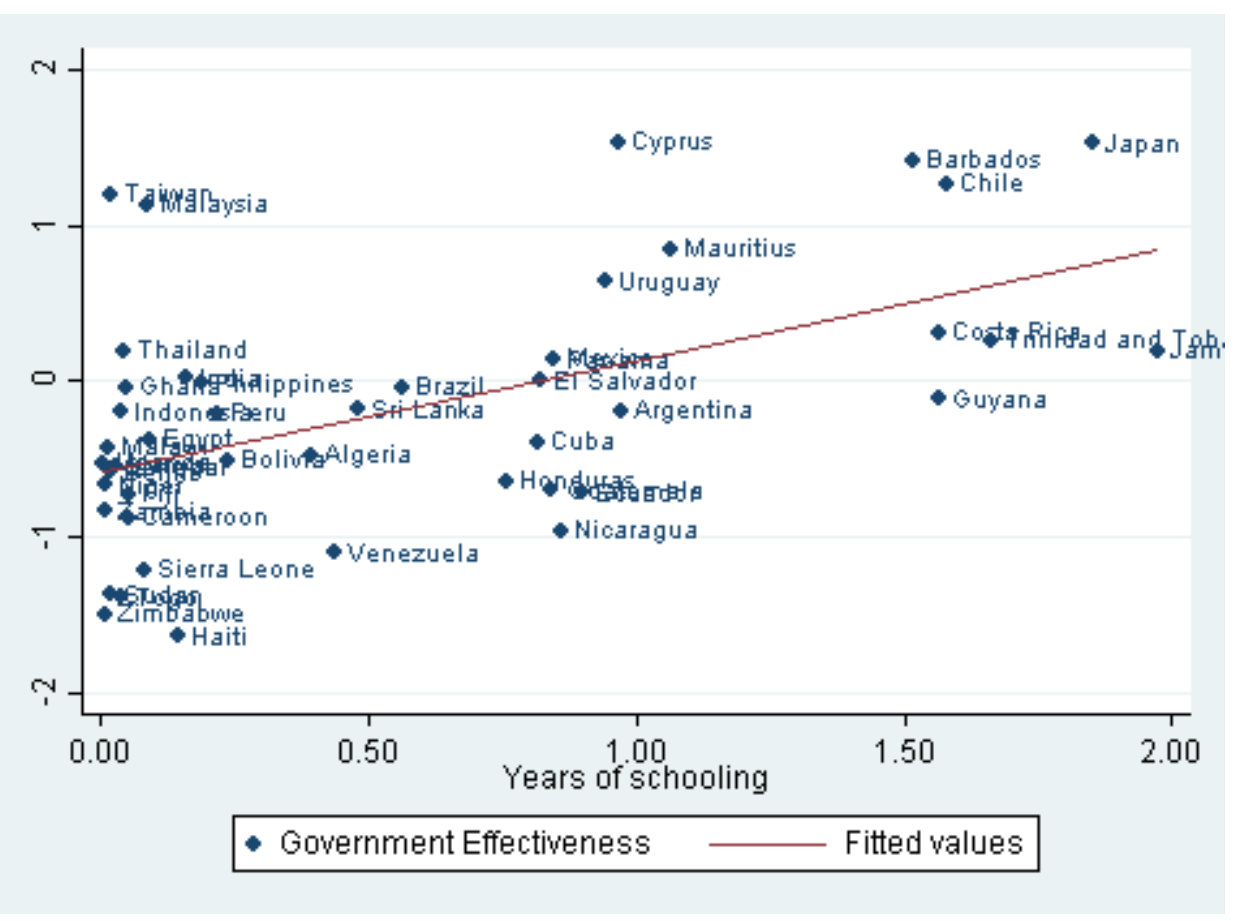


Table 4.3: Historical State Capacity and Colonial Education Policy

\begin{tabular}{lcccc}
\hline VARIABLES & $\begin{array}{c}\text { Model 1 } \\
\text { Educational } \\
\text { Attainment } \\
\text { In 1900 }\end{array}$ & $\begin{array}{c}\text { Model 2 } \\
\text { World Bank } \\
\text { Government } \\
\text { Effectiveness } \\
\text { In 2010 }\end{array}$ & $\begin{array}{c}\text { Model 3 } \\
\text { World Bank } \\
\text { Government } \\
\text { Effectiveness } \\
\text { In 2010 }\end{array}$ & $\begin{array}{c}\text { Model 4 } \\
\text { Educational } \\
\text { Attainment } \\
\text { In 1900 }\end{array}$ \\
\hline $\begin{array}{l}\text { State Capacity in } \\
1500\end{array}$ & $\begin{array}{c}-0.0115^{* * *} \\
(0.004)\end{array}$ & $\begin{array}{c}-0.00220 \\
(0.006)\end{array}$ & & \\
State Capacity in & & & -0.00132 & 0.00631 \\
1850 & & & $(0.007)$ & $(0.005)$ \\
Constant & $0.697 * * *$ & $-0.289 * *$ & -0.285 & 0.237 \\
& $(0.103)$ & $(0.140)$ & $(0.273)$ & $(0.209)$ \\
Observations & 61 & 54 & 54 & 61 \\
R-squared & 0.124 & 0.003 & 0.001 & 0.022 \\
\hline
\end{tabular}

Standard errors in parentheses

$* * * \mathrm{p}<0.01, * * \mathrm{p}<0.05, * \mathrm{p}<0.10$ 
Table 4.4: World Bank Government Effectiveness and Educational attainment in 1900

\begin{tabular}{|c|c|c|c|}
\hline & $\begin{array}{c}\text { World Bank } \\
\text { Government } \\
\text { Effectiveness } \\
\text { Model } 5 \\
\end{array}$ & $\begin{array}{c}\text { World Bank } \\
\text { Government } \\
\text { Effectiveness } \\
\text { Model } 6 \\
\end{array}$ & $\begin{array}{c}\text { World Bank } \\
\text { Government } \\
\text { Effectiveness } \\
\text { Model } 7 \\
\end{array}$ \\
\hline $\begin{array}{l}\text { Educational } \\
\text { attainment in } 1900\end{array}$ & $\begin{array}{c}0.326^{* * *} \\
(0.111)\end{array}$ & $\begin{array}{c}0.341 * * * \\
(0.110)\end{array}$ & $\begin{array}{c}0.279 * * \\
(0.112)\end{array}$ \\
\hline $\begin{array}{l}\text { Level of European } \\
\text { Settlement }\end{array}$ & $\begin{array}{l}0.982 * \\
(0.512)\end{array}$ & $\begin{array}{l}1.109 * * \\
(0.518)\end{array}$ & $\begin{array}{l}1.394 * * \\
(0.559)\end{array}$ \\
\hline Statehood in 1500 & & $\begin{array}{c}0.00672 \\
(0.00513)\end{array}$ & \\
\hline Statehood in 1850 & & & $\begin{array}{l}-0.0113 * \\
(0.00672)\end{array}$ \\
\hline Constant & $\begin{array}{c}-0.621 * * * \\
(0.0931)\end{array}$ & $\begin{array}{c}-0.772 * * * \\
(0.148)\end{array}$ & $\begin{array}{l}-0.257 \\
(0.235)\end{array}$ \\
\hline $\begin{array}{l}\text { Observations } \\
\text { R-squared }\end{array}$ & $\begin{array}{c}56 \\
0.565\end{array}$ & $\begin{array}{c}56 \\
0.579\end{array}$ & $\begin{array}{c}56 \\
0.588\end{array}$ \\
\hline
\end{tabular}

Standard errors in parentheses

$* * * \mathrm{p}<0.01, * * \mathrm{p}<0.05, * \mathrm{p}<0.1$ 
Table 4.5: World Bank Government Effectiveness and Educational Attainment without NeoEuropes

\begin{tabular}{lccc}
\hline & $\begin{array}{c}\text { World Bank } \\
\text { Government } \\
\text { Effectiveness } \\
\text { Model 8 }\end{array}$ & $\begin{array}{c}\text { World Bank } \\
\text { Government } \\
\text { Effectiveness } \\
\text { Model 9 }\end{array}$ & $\begin{array}{c}\text { World Bank } \\
\text { Government } \\
\text { Effectiveness } \\
\text { Model 10 }\end{array}$ \\
\hline Educational & $0.577 * * *$ & $0.644^{* * *}$ & $0.539 * * *$ \\
attainment level in & $(0.170)$ & $(0.172)$ & $(0.170)$ \\
1900 & & & \\
Level of European & 0.539 & 0.717 & 1.048 \\
settlement & $(0.586)$ & $(0.585)$ & $(0.663)$ \\
Statehood in 1500 & & $0.00883 *$ & \\
Statehood in 1850 & & $(0.00517)$ & \\
& & & -0.0112 \\
Constant & & & $(0.00715)$ \\
& $-0.681^{* * *}$ & $-0.901^{* * *}$ & -0.334 \\
Observations & $(0.107)$ & $(0.166)$ & $(0.245)$ \\
R-squared & 52 & 52 & 52 \\
\hline & 0.326 & 0.365 & 0.359 \\
\hline
\end{tabular}

Standard errors in parentheses $* * * \mathrm{p}<0.01, * * \mathrm{p}<0.05, * \mathrm{p}<0.1$ 
Table 4.6: ICRG Bureaucratic Quality and Educational Attainment Levels without Neo-Europes

\begin{tabular}{|c|c|c|c|}
\hline VARIABLES & $\begin{array}{c}\text { ICRG } \\
\text { Bureaucratic } \\
\text { Quality } \\
\text { Model } 11 \\
\end{array}$ & $\begin{array}{c}\text { ICRG } \\
\text { Bureaucratic } \\
\text { Quality } \\
\text { Model } 12 \\
\end{array}$ & $\begin{array}{c}\text { ICRG } \\
\text { Bureaucratic } \\
\text { Quality } \\
\text { Model } 13 \\
\end{array}$ \\
\hline $\begin{array}{l}\text { Educational } \\
\text { attainment in } 1900\end{array}$ & $\begin{array}{l}0.168 * * \\
(0.0641)\end{array}$ & $\begin{array}{c}0.204 * * * \\
(0.0618)\end{array}$ & $\begin{array}{l}0.173 * * \\
(0.0646)\end{array}$ \\
\hline $\begin{array}{l}\text { Level of European } \\
\text { settlement }\end{array}$ & $\begin{array}{l}-0.0747 \\
(0.215)\end{array}$ & $\begin{array}{l}0.0261 \\
(0.206)\end{array}$ & $\begin{array}{l}-0.164 \\
(0.243)\end{array}$ \\
\hline Statehood in 1500 & & $\begin{array}{c}0.00492 * * * \\
(0.00181)\end{array}$ & \\
\hline Statehood in 1850 & & & $\begin{array}{c}0.00202 \\
(0.00252)\end{array}$ \\
\hline Constant & $\begin{array}{c}0.428 * * * \\
(0.0378)\end{array}$ & $\begin{array}{l}0.294 * * * \\
(0.0609)\end{array}$ & $\begin{array}{l}0.362 * * * \\
(0.0901)\end{array}$ \\
\hline $\begin{array}{l}\text { Observations } \\
\text { R-squared }\end{array}$ & $\begin{array}{c}54 \\
0.148\end{array}$ & $\begin{array}{c}54 \\
0.257\end{array}$ & $\begin{array}{c}54 \\
0.158\end{array}$ \\
\hline
\end{tabular}


Table 4.7: World Bank Tax Ratio and Educational Attainment in 1900 without Neo-Europes

\begin{tabular}{lccc}
\hline & $\begin{array}{c}\text { World Bank } \\
\text { Tax Ratio } \\
\text { Model 14 }\end{array}$ & $\begin{array}{c}\text { World Bank } \\
\text { Tax Ratio } \\
\text { Model 15 }\end{array}$ & $\begin{array}{c}\text { World Bank } \\
\text { Tax Ratio } \\
\text { Model 16 }\end{array}$ \\
\hline Educational & $4.867^{* *}$ & $4.615^{* *}$ & $3.936^{*}$ \\
attainment in 1900 & $(1.974)$ & $(2.135)$ & $(1.986)$ \\
Level of European & -2.199 & -1.425 & 6.454 \\
settlement & $(7.407)$ & $(7.805)$ & $(8.276)$ \\
Statehood in 1500 & & 0.0105 & \\
Statehood in 1850 & & $(0.0669)$ & \\
& & & $-0.167 *$ \\
Constant & & & $(0.0842)$ \\
& $(1.271)$ & $(2.081)$ & $(2.756)$ \\
Observations & $3.93 * * *$ & 35 & 35 \\
R-squared & 0.212 & 0.188 & 0.279 \\
\hline
\end{tabular}

Standard errors in parentheses

$* * * \mathrm{p}<0.01, * * \mathrm{p}<0.05, * \mathrm{p}<0.1$ 
Table 4.8: State Capacity and Educational Attainment with Colony Dummy without Neo-Europes

\begin{tabular}{|c|c|c|c|}
\hline & $\begin{array}{l}\text { World Bank } \\
\text { Tax Ratio } \\
\text { Model } 17\end{array}$ & $\begin{array}{c}\text { World Bank } \\
\text { Government } \\
\text { Effectiveness } \\
\text { Model } 18\end{array}$ & $\begin{array}{c}\text { ICRG } \\
\text { Bureaucratic } \\
\text { Quality } \\
\text { Model } 19\end{array}$ \\
\hline $\begin{array}{l}\text { Educational } \\
\text { attainment in } 1900\end{array}$ & $\begin{array}{l}4.732 * * \\
(2.264)\end{array}$ & $\begin{array}{c}0.600 * * * \\
(0.168)\end{array}$ & $\begin{array}{l}0.159 * * * \\
(0.0523)\end{array}$ \\
\hline $\begin{array}{l}\text { Level of European } \\
\text { settlement }\end{array}$ & $\begin{array}{l}-2.057 \\
(8.670)\end{array}$ & $\begin{array}{l}1.177 * \\
(0.617)\end{array}$ & $\begin{array}{l}0.483 * * \\
(0.196)\end{array}$ \\
\hline Statehood in 1500 & $\begin{array}{l}0.00997 \\
(0.0681)\end{array}$ & $\begin{array}{l}0.0107 * * \\
(0.00513)\end{array}$ & $\begin{array}{c}0.00545 * * * \\
(0.00151)\end{array}$ \\
\hline British settlement & $\begin{array}{l}-0.381 \\
(2.113)\end{array}$ & $\begin{array}{l}0.312 * \\
(0.162)\end{array}$ & $\begin{array}{l}0.240 * * * \\
(0.0498)\end{array}$ \\
\hline Constant & $\begin{array}{c}13.87 * * * \\
(2.373)\end{array}$ & $\begin{array}{c}-1.114^{* * *} \\
(0.196)\end{array}$ & $\begin{array}{l}0.135 * * \\
(0.0605)\end{array}$ \\
\hline $\begin{array}{l}\text { Observations } \\
\text { R-squared }\end{array}$ & $\begin{array}{c}35 \\
0.189\end{array}$ & $\begin{array}{c}52 \\
0.411\end{array}$ & $\begin{array}{c}54 \\
0.496\end{array}$ \\
\hline
\end{tabular}


Table 4.9: World Bank Government Effectiveness and Educational Attainment given Geography and $G D P$

\begin{tabular}{|c|c|c|c|}
\hline VARIABLES & $\begin{array}{c}\text { World Bank } \\
\text { Government } \\
\text { Effectiveness } \\
\text { Model } 20 \\
\end{array}$ & $\begin{array}{c}\text { World Bank } \\
\text { Government } \\
\text { Effectiveness } \\
\text { Model } 21 \\
\end{array}$ & $\begin{array}{c}\text { World Bank } \\
\text { Government } \\
\text { Effectiveness } \\
\text { Model } 22 \\
\end{array}$ \\
\hline $\begin{array}{l}\text { Educational } \\
\text { Attainment in } 1900\end{array}$ & $\begin{array}{l}0.283 * * * \\
(0.0715)\end{array}$ & $\begin{array}{c}0.752 * * * \\
(0.199)\end{array}$ & $\begin{array}{l}0.410 * \\
(0.217)\end{array}$ \\
\hline Level of settlement & $\begin{array}{c}0.329 \\
(0.631)\end{array}$ & $\begin{array}{l}1.418 * * \\
(0.634)\end{array}$ & $\begin{array}{c}0.305 \\
(0.751)\end{array}$ \\
\hline $\begin{array}{l}\text { State Capacity in } \\
1500\end{array}$ & & $\begin{array}{l}0.0117 * * \\
(0.00512)\end{array}$ & $\begin{array}{c}0.00575 \\
(0.00603)\end{array}$ \\
\hline $\begin{array}{l}\text { State Capacity in } \\
1850\end{array}$ & $\begin{array}{l}-0.00743 \\
(0.00637)\end{array}$ & & \\
\hline British settlement & & $\begin{array}{c}0.269 \\
(0.163)\end{array}$ & $\begin{array}{c}0.208 \\
(0.190)\end{array}$ \\
\hline Region (geography) & & $\begin{array}{l}-0.0284 \\
(0.020)\end{array}$ & $\begin{array}{l}-0.0277 \\
(0.023)\end{array}$ \\
\hline Logged GDP/capita & & & $\begin{array}{c}0.401 * * * \\
(0.128)\end{array}$ \\
\hline Constant & & $\begin{array}{c}-0.871 * * * \\
(0.260)\end{array}$ & $\begin{array}{c}-3.642 * * * \\
(0.955)\end{array}$ \\
\hline $\begin{array}{l}\text { Observations } \\
\text { R-squared }\end{array}$ & & $\begin{array}{c}52 \\
0.435\end{array}$ & $\begin{array}{c}36 \\
0.495\end{array}$ \\
\hline
\end{tabular}


Table 4.10: State Capacity and Educational Attainment with Colony Dummy without NeoEuropes

\begin{tabular}{lc}
\hline & $\begin{array}{c}\text { Educational } \\
\text { attainment in } \\
1950 \\
\text { Model } 23\end{array}$ \\
\hline Educational & $2.073 * * *$ \\
attainment in & $(0.267)$ \\
1900 & \\
Constant & $1.153 * * *$ \\
& $(0.194)$ \\
Observations & 60 \\
R-squared & 0.511 \\
\hline $\begin{array}{l}\text { Standard errors in parentheses } \\
* * *\end{array}<0.01, * * \mathrm{p}<0.05, * \mathrm{p}<0.10$
\end{tabular}

Figure 4.3: Educational attainment in 1900 and 1950

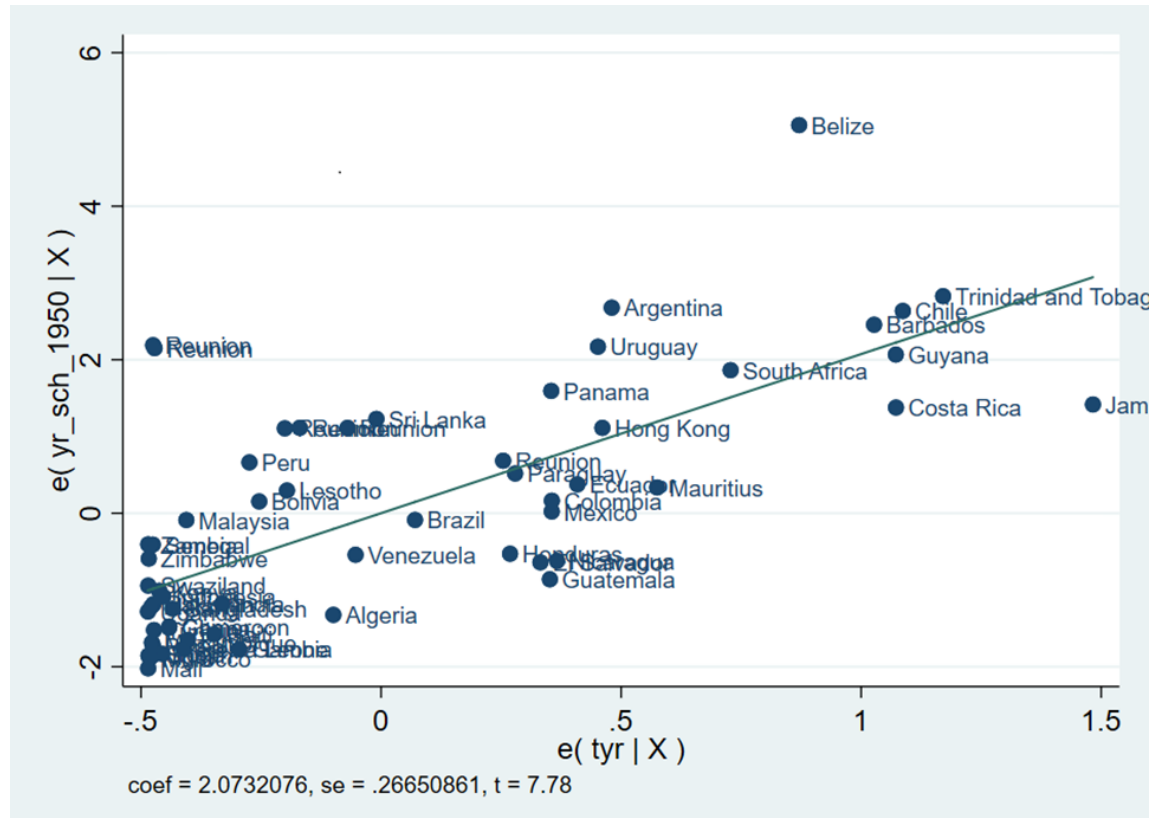




\section{Appendix}

Table 4.11: ICRG Bureaucratic Quality and Educational Attainment Levels with Neo-Europes

\begin{tabular}{|c|c|c|c|c|}
\hline VARIABLES & $\begin{array}{c}\text { ICRG } \\
\text { Bureaucratic } \\
\text { Quality } \\
\text { Model } 24 \\
\end{array}$ & $\begin{array}{c}\text { ICRG } \\
\text { Bureaucratic } \\
\text { Quality } \\
\text { Model 25 } \\
\end{array}$ & $\begin{array}{c}\text { ICRG } \\
\text { Bureaucratic } \\
\text { Quality } \\
\text { Model 26 } \\
\end{array}$ & $\begin{array}{c}\text { ICRG } \\
\text { Bureaucratic } \\
\text { Quality } \\
\text { Model } 27 \\
\end{array}$ \\
\hline $\begin{array}{l}\text { Education } \\
\text { attainment in } 1900\end{array}$ & $\begin{array}{c}0.109 * * * \\
(0.04)\end{array}$ & $\begin{array}{l}0.119 * * * \\
(0.0384)\end{array}$ & $\begin{array}{l}0.114 * * * \\
(0.0413)\end{array}$ & $\begin{array}{l}0.0205 \\
(0.04 \\
(0.0368)\end{array}$ \\
\hline $\begin{array}{l}\text { Level of European } \\
\text { Settler }\end{array}$ & $\begin{array}{l}0.0701 \\
(0.183)\end{array}$ & $\begin{array}{c}0.159 \\
(0.178)\end{array}$ & $\begin{array}{l}0.0224 \\
(0.201)\end{array}$ & $\begin{array}{r}-0.184 \\
(0.16)\end{array}$ \\
\hline Statehood in 1500 & & $\begin{array}{l}0.00443 * * \\
(0.00177)\end{array}$ & & $\begin{array}{c}0.00408 * * * \\
(0.002)\end{array}$ \\
\hline Statehood in 1850 & & & $\begin{array}{c}0.00137 \\
(0.00232)\end{array}$ & \\
\hline $\begin{array}{l}\text { Education } \\
\text { Attainment in } 1950\end{array}$ & & & & $\begin{array}{c}0.105 * * * \\
(0.02)\end{array}$ \\
\hline Constant & $\begin{array}{l}0.439 * * * \\
(0.0318)\end{array}$ & $\begin{array}{l}0.328 * * * \\
(0.0540)\end{array}$ & $\begin{array}{l}0.393 * * * \\
(0.0853)\end{array}$ & $\begin{array}{c}0.204 * * * \\
(0.0502)\end{array}$ \\
\hline $\begin{array}{l}\text { Observations } \\
\text { R-squared }\end{array}$ & $\begin{array}{c}58 \\
0.354\end{array}$ & $\begin{array}{c}58 \\
0.421\end{array}$ & $\begin{array}{c}58 \\
0.358\end{array}$ & $\begin{array}{c}58 \\
0.617\end{array}$ \\
\hline
\end{tabular}

Standard errors in parentheses $* * * \mathrm{p}<0.01, * * \mathrm{p}<0.05, * \mathrm{p}<0.10$ 
Table 4.12: World Bank Tax Ratio and Educational Attainment in 1900 with Neo-Europes

\begin{tabular}{|c|c|c|c|c|}
\hline VARIABLES & $\begin{array}{c}\text { World Bank } \\
\text { Tax Ratio } \\
\text { Model } 28 \\
\end{array}$ & $\begin{array}{c}\text { World Bank } \\
\text { Tax Ratio } \\
\text { Model } 29 \\
\end{array}$ & $\begin{array}{c}\text { World Bank } \\
\text { Tax Ratio } \\
\text { Model } 30 \\
\end{array}$ & $\begin{array}{c}\text { World Bank } \\
\text { Tax Ratio } \\
\text { Model } 31\end{array}$ \\
\hline $\begin{array}{l}\text { Education } \\
\text { attainment in } 1900\end{array}$ & $\begin{array}{l}0.236 \\
(1.42)\end{array}$ & $\begin{array}{l}0.0112 \\
(1.44)\end{array}$ & $\begin{array}{l}-0.644 \\
(1.39)\end{array}$ & $\begin{array}{r}-1.939 \\
(1.76)\end{array}$ \\
\hline $\begin{array}{l}\text { Level of European } \\
\text { Settlement }\end{array}$ & $\begin{array}{l}2.486 \\
(6.75)\end{array}$ & $\begin{array}{l}2.555 \\
(7.00)\end{array}$ & $\begin{array}{l}9.918 \\
(7.09)\end{array}$ & $\begin{array}{l}-5.655 \\
(8.16)\end{array}$ \\
\hline Statehood in 1500 & & $\begin{array}{l}-0.0333 \\
(0.0720)\end{array}$ & & $\begin{array}{c}-0.0381 \\
(0.07)\end{array}$ \\
\hline Statehood in 1850 & & & $\begin{array}{c}-0.189 * * \\
(0.0855)\end{array}$ & \\
\hline $\begin{array}{l}\text { Education } \\
\text { attainment in } 1950\end{array}$ & & & & $\begin{array}{l}2.191 * \\
(1.21)\end{array}$ \\
\hline Constant & $\begin{array}{c}15.67 * * * \\
(1.229)\end{array}$ & $\begin{array}{c}16.20 * * * \\
(1.974)\end{array}$ & $\begin{array}{c}21.29 * * * \\
(2.878)\end{array}$ & $\begin{array}{l}14.20 * * * \\
(2.209)\end{array}$ \\
\hline Observations & 40 & 39 & 39 & 39 \\
\hline R-squared & 0.028 & 0.034 & 0.147 & 0.119 \\
\hline
\end{tabular}


Table 4.13: Colonial education and state capacity

Table 13: Colonial education and state capacity

\begin{tabular}{lcc}
\hline \hline & $\Delta$ State Capacity & $95 \%$ CIs \\
\hline Educational Attainment, 1900 & & \\
$\quad 0.04 \longrightarrow 0.558$ & $+0.289^{*}$ & {$[0.110,0.479]$} \\
European Settlement & & \\
$0 \longrightarrow 0.162$ & +0.181 & {$[-0.031,0.398]$} \\
Statehood, 1850 & & \\
$25 \longrightarrow 37.54$ & -0.097 & {$[-0.299,0.107]$} \\
British Settlement & & \\
$0 \longrightarrow 1$ & +0.156 & {$[-0.225,0.543]$} \\
\hline \hline
\end{tabular}




\section{Chapter V: THE EVOLUTION OF EDUCATION, THE BUREAUCRACY, AND ECONOMIC ACCESS IN COLONIAL INDONESIA}

"Colonial policy tends to follow, even at a distance, domestic policy. Liberty, social justice, democracy, if approved as sauce for the domestic goose, are served up a little later with the colonial policy..." -John Sydenham Furnivall, 2014, 7

Several studies argue that colonial policies were shaped by the domestic sociopolitical and economic conditions of the colonial regime (Acemoglu, Johnson, and Robinson 2001; Banerjee and Iyer 2005; Easterly and Levine 2003; Englebert 2000; Evans and Rauch 1999; Kohli 1994; Lange 2003; Lange, Mahoney, and vom Hau 2006; Sacerdote and Feyrer 2009). As presently noted, this observation is often translated into two underlying assumptions: first, metropolitan institutional frameworks were replicated in colonial territories (Englebert 2000; Evans and Rauch 1999; Kohli 1994); and second, that process of replication occurred with relative consistency in colonial projects the world over. These studies, therefore, often also account for patterns of similarity and divergence in how these institutions endured or didn't after independence. ${ }^{29}$

In previous chapters, I argued that an additional mechanism facilitating institutional durability from the colonial to the post-colonial period is investment by colonial regimes in the educational attainment of colonized populations. This chapter explores this mechanism in The Netherlands East Indies—modern day Indonesia—first under the Dutch East India Company (Vereenigde Oost-Indische Compagnie) and later under state bureaucrats assigned by the Dutch crown.

\footnotetext{
${ }^{29}$ Frankema (2013), Lange (2009), Mahoney (2010), Matsuzaki (2019), and Migdal et al. (1994) provide some insight into how institutional transmission occurs during the colonial period.
} 
The Netherlands East Indies prior to the Japanese occupation (1942-1945) demonstrates the importance of education for the development of a colonized population, and ultimately for state building. Moreover, as a case study, it illustrates the causal mechanism of colonial inclusivity. The overarching story told here is that beginning in the middle of the $19^{\text {th }}$ century, the Dutch central government began an education project that expanded access to education from mainly native elites to the general population as well. The shift in Dutch policy, which contributed to the expansion of education to a large segment of the Javanese and Sumatran ${ }^{30}$ populations before 1942, had positive consequences for the development of the Weberian bureaucracy, in these central parts of the archipelago.

By the latter half of the $19^{\text {th }}$ century, Dutch education policy in the archipelago began to morph into an explicit project to graft the indigenous population into the colonial bureaucracy, with the skills necessary to permit colonial expansion beyond Java and Sumatra. Even though this movement towards a more inclusive colonial state was not consistent for many of the remaining years of Dutch parliament control over the archipelago, by independence civil society flourished as the indigenous population experienced greater access to quality education — in terms of being trained in the skills needed for Weberian bureaucrats - and greater autonomy, both at the village level and in the Pangreh Praja, the native bureaucratic corps.

\footnotetext{
${ }^{30}$ During most of the Dutch's control over Indonesia, there operations were centralized in Sumatra and Java. It was not until the early $20^{\text {th }}$ century that the Dutch began to expand control to outer islands. This was made possible by migrating well educated indigenous bureaucrats from Sumatra and Java to these outer islands. Given that Java and Sumatra were the administrative centers of the Dutch East Indies, education expansion was also geographically concentrated there as well.
} 
The reasons for the shift in Dutch policy in the archipelago are likely due in part to the rise of classical liberalism in Europe, which occurred in The Netherlands in the $19^{\text {th }}$ century (de Beus 2006; te Velde 2008). As the liberalizing parliament and Dutch monarchy gained greater control in The Netherlands East Indies relative to the VOC, major shifts in colonial policies occurred. Thus, colonial education and economic policies, along with institution building vacillated in tandem with the uneven gains and retractions of constitutional liberalism in The Netherlands. Moreover, expansions of liberalization and education expansion were not evenly dispersed throughout the archipelago, rather they largely concentrated in Java and Sumatra. At the end of the $19^{\text {th }}$ century, a growing economic interest in expanding to the outer islands of the archipelago, combined with the post-1848 popularity of constitutional liberalism that led to significant improvements in colonial education. These improvements facilitated the continuity of Weberian bureaucratic structures that, in turn, contributed to higher levels of state capacity in contemporary Indonesia.

The core argument of this chapter is graphically depicted in Figure 1 and 2 below.

Figure 5.1: The Effect of Colonial Investment in Education on State Capacity

\begin{tabular}{|c|}
$\begin{array}{c}\text { Colonial } \\
\text { Investment in } \\
\text { Education }\end{array}$ \\
Contemporary \\
State Capacity
\end{tabular}


Figure 5.2: The Process of Colonial Inclusivity Development in Indonesia

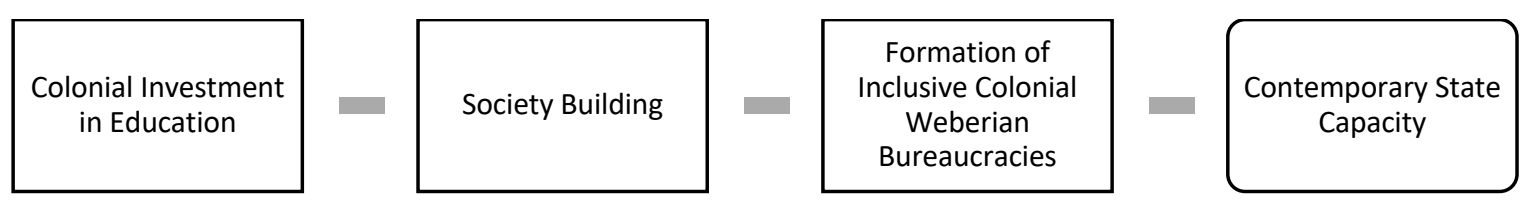

Figure 1 demonstrates the effect of colonial inclusive policies, like investing in the education of the indigenous population, on the development of contemporary state capacity. Figure 2 provides a more nuanced process tracing of the influence of colonial investment in education on the contemporary state capacity. The Dutch parliament's investment in the education of the population in The Netherlands East Indies provided the socialization necessary for adjusting to the Dutch parliament's imposed new institutional rules governing society. I argue that this socialization emboldened civil society in The Netherlands East Indies and equipped the non-European population to be professionalized into the institutions being transmitted by the Dutch. Therefore, education served a dual function of socializing and professionalizing the population in a manner that makes the Netherlands East Indies ripe for the institutional transmission the literature asserts. Additionally, prior to 1942 Indonesia was positioned for the higher levels of contemporary state capacity comparable to Mauritius and Singapore. ${ }^{31}$

Before moving forward, it is important to mention that the gains made for the Indonesian population in the decades before independence were nearly upended by the occupation of the Japanese military from 1942-1945. Once the Japanese arrived in the archipelago, they quickly worked to expel all traces of the Dutch influence on education. This included either sending Dutch educators back to The Netherlands or imprisoning

\footnotetext{
${ }^{31}$ On a scale from - 2.5 to 2.5 , in 2017 Singapore's government effectiveness value was 2.21 and Mauritius' government effectiveness value was 0.90 . Comparatively, Indonesia's government effectiveness value was 0.04 .
} 
them, changing the language of instruction from Dutch to Japanese, and implementing a curriculum of Japanese propaganda. While this did not eliminate the effects of education altogether, it did make the curriculum more nationalistic, which in large doses is not healthy for state building. I discuss this further later in the chapter. I do recognize that the adverse effect of the Japanese occupation on education and the bureaucracy in The Netherlands East Indies seems counter-intuitive given the studies that argue that Japanese colonialism in South Korea had positive ramifications for their institutions and long-term economic development (Kohli 1994). Even still, the circumstances under which Japan arrived in Southeast Asia during World War II (Sagan 1988) led to strikingly different policies compared to Taiwan and Korea.

Overall, this chapter provides a deeper explanation for why colonial education policies matter for contemporary state capacity by exploring the underlying causal processes of the colonial inclusivity mechanism. In contexts where educational access for the indigenous population was greater, due to increased investment, the confluence of colonial education and the transformation of the bureaucracy set the stage for healthy post-independence state building. Conversely, this case provides some evidence that absent significant gains in the colonized population's access to quality education, even the strongest colonial institutions did not put former colonies in the best position to build lasting strong state capacity.

I begin this assessment by exploring the preconditions of colonial education expansion in The Netherlands East Indies: The Dutch parliament and entrepreneurs' economic interests and the spread of classical liberalism in The Netherlands government. I then assess the evolution of Dutch colonial education policies in The Netherlands East 
Indies from just before the classical liberal period (pre-1850), through the transition period (1850-1942), and to the post-independence period.

\subsection{The Netherlands Economic Climate in the $19^{\text {th }}$ and early $20^{\text {th }}$ Century}

First, a precondition for the expansion of education in the Netherlands East Indies is the metropoles economic interests in the late $19^{\text {th }}$ century and the early part of the $20^{\text {th }}$ century. During this period that the VOC lost control of the archipelago, and the the Netherlands' parliament and monarchy took over operations in the East Indies. Prior to and more so after this switch in leadership, the The Dutch parliament and entrepreneurs"s economic interests in the archipelago were to expand operations to territories outside of Java and Sumatra via military means (Locher-Scholten 1994), to offset costs incurred during the Napoleonic Wars. This restructuring of the Netherlands and Netherlands East Indies relations set the groundwork for an efficient taxation system that increased revenues in both locales. These early institutional structures paved the way for more professionalized bureaucratic structures, akin to Weberian bureaucracies discussed in Chapter II. Additionally, this increase in revenues in the Netherlands partially served as a motivation to reinvest these funds in the population of the Netherlands East Indies. The tipping point for a deep sense of obligation to reinvest in the colony was created by the emergence of liberal ideologies and reforms discussed in the next section.

At the beginning of the $19^{\text {th }}$ century, the Netherlands was still being ruled by France under Napoleon Bonaparte. It was during France's control over the Netherlands that the plan to expand the Dutch colonial project in the archipelago beyond Java was 
first articulated. In 1806, Napoleon appointed his younger brother, Louis Napoleon, to rule as king of the Netherlands. Subsequently, King Louis appointed Marshal Daendels to restore order in Java, prevent a potential attack by the British, and launch a project to bring a larger portion of the archipelago under Dutch control (Thee 2013, 43). At the time, the treasury in Java was empty, making expanding to other territories unfeasible, but Marshal Daendels managed to construct a highway—by conscripting large amounts of peasant workers who died in droves - before Java was overtaken by the British in 1811.

The highway constructed during Marshal Daendels' governorship and the subsequent occupation of The Netherlands East Indies by the British set the stage for a reformation in extraction from The Netherlands East Indies that would have ramifications later for the investment in colonial education. ${ }^{32}$ During the British interregnum (18061815), the now infamous Thomas Raffles' tenure in Java led to the reformation of the colonial administration from the corrupt and fractured VOC (Netherlands East India Company) operation to a more stable bureaucracy. This included the introduction of a land tax, which was inspired by the British land tax in Bengal and which required peasant cultivators in Java to pay two-fifths of their yield to the British. Even though this new system of extracting taxes was effective, much of the revenue was embezzled by district heads. Moreover, even though the British tenure in Java was brief, this tax system set a new precedent for extraction from the the colony, which had implications for the emergence of western education in The Netherlands East Indies.

\footnotetext{
${ }^{32}$ There is some basis in the literature by scholars who argue that the reach of the state (Scott 1998) is expanded by the creation of highways.
} 
This new taxation system remained, after the British relinquished control back to the Netherlands in 1815. Once bureaucrats from the Netherlands returned to the archipelago after the Napoleonic Wars, they established the General Commissioners who created a new land tax that was achieved through bargaining between villagers and government officials (Gonggrijp 1949: 76-7). Once the Dutch subdued Java at the end of the Java War (1825-1830) and were able to streamline their tax extraction from Java and Sumatra, they were able to focus on conquering other islands (Thee 2013, 44).

The new taxation system in the archipelago put The Netherlands in a position to be able to recover fiscally from the Napoleonic Wars by increasing its exploitation of The Netherlands East Indies. By the middle of the $19^{\text {th }}$ century, this shift occurred as the Dutch attempted to recover from not only the Napoleonic Wars, but also from the decrease in foreign trade with the British as a result of competition over colonial territory, the Belgian revolt of 1830-1, and the expenditures incurred during the Java War (18251830). By the time of Belgium's secession from The Netherlands in 1830, The Netherlands was near bankruptcy and The Netherlands East Indies had a debt amounting to 40 million guilders (van den Doel 1996: 48-50). These economic setbacks positioned The Netherlands for relying heavily on Java and an expansion into the outer islands in order to recuperate some fiscal and material resources. While this decision led to a greater degree of exploitation in The Netherlands East Indies, it also set the stage for shifts in educational policies, as the demand for skilled agricultural labor in The Netherlands East Indies increased with this necessity.

The fiscal setbacks both at home and abroad began to reverse when former military officer Johannes van den Bosch took over as Governor General in the 
archipelago. Under his tutelage, the East Indies colonial government began to oversee the cultivation process to increase their revenues. This led to the introduction of the cultivation system, Cultuurstelsel (CS), with the goal of sending the profits from cultivation directly to the Dutch treasury (Booth 1998: 138). This system required peasants to pay one-fifth of their total production value, either in cash or crops, to the Indies colonial government as a land rent tax. Moreover, the emphasis on lucrative crops such as indigo and sugar, stagnated the production of rice and cash crops, which reduced the liberties of peasant workers to cultivate crops more crucial for their own subsistence, and which contributed to a deeper colonial infiltration of Javanese society (Boomgard 1989: 36). While this undermined the human capital of the indigenous population, it also created a considerable increase in the level of revenues for the Dutch treasury, a total of 684 million guilders between 1832-1877 (Burger 1975: 120). ${ }^{33}$ The revenues from The Netherlands East Indies amounted to one-third of the Dutch economy every year by the late $19^{\text {th }}$ century (Fasseur 1992: 149-50).

Even though this period is marked by material abundance in the Netherlands, as a result of extreme exploitation of the labor and production of the native population in the Netherlands East Indies, there are those who argue that the material living conditions of at least the Javanese improved during the CS period (Elson 1997). This view is held because at its height, the peasants' revenues always exceeded the one-fifth they owed to the Indies government versus the two-fifths they owed under the British land tax system (Elson 1994: 310-311). Arguably, this increased the material wealth of the colonized population, even though it was unfair. This argument may be persuasive if we consider

\footnotetext{
${ }^{33}$ The present equivalent of $\$ 348,360,800$.
} 
that this period led to the reformation of the economy in ways that improved the skills and abilities of peasant populations, allowing them to respond to commercial opportunities in the long term (Elson 1994: 317).

\subsection{The Rise of Classical Constitutional Liberalism in the Netherlands}

A second precondition for the ultimate expansion of education to a larger segment of the native population was the rise of classical liberalism in the Netherlands. Historians have marked the rise of classical or constitutionalism liberalism in the Netherlands as the gradual shift that occurred from the middle of the $19^{\text {th }}$ century to the early part of the $20^{\text {th }}$ century (1848-1918). This shift in the Netherlands was in response to the transition of the world and Europe in particular, to a Westphalian system. At the height of this time of nation-state formation, the mission of higher education institutions was to reinforce nationalization, democratization, and public service. After 1500, the mission of European universities switched from preparing students for teaching and learned professions (Cobban 1992, 227-228), to becoming bastions for advancing national purposes as the "ideological arm of the state" (Readings 1996, 45-46; Scott 1998, 110-111) and to a certain extent this switch in focus extended to the former colonies of France, Spain, and Britain (Schwartzman 1992, 973), as well as the Netherlands as I illustrate here.

This rise of classical liberalism in the Netherlands was solidified by the passing of the new constitution in 1848 , the mounting influence of liberal parties, and the abolition of the royal patriarchy under the helm of Johan Rudolph Thorbecke (1798-1872) who became prime minister of the parliament (de Beus 2006). The 1848 constitution introduced the rule of law, made headway for societal freedoms, and assigned clear 
responsibilities to the government and parliament. Specifically, at the core of Dutch liberalism was an emphasis on individual freedom with restraint (te Velde 2008), constitutional monarchy, balance of power between the branches of government, sovereignty of the Dutch state, ministerial responsibility and unity of cabinet policy, basic rights and liberties for all citizens, foreign policy, centralization of defense, free elections, private property rights, justice and police, industrial infrastructure, education, assistance to the poor, arts and sciences, and colonial policy (de Beus 2006, 86).

The scope of liberalism in the Netherlands led to the increase of social legislation that regulated society in a structural way (te Velde 2008, 69), which had implications for metropolitan education policies. During this time, the Dutch government assumed that there should be a clear delineation between religion and society, such that the public space would remain neutral $(2008,69)$. This also meant that bridging between the state and society was not the intent of Dutch liberals. Rather, political representation was meant to anticipate what rational voters would want, and not engage with civil society to intuit what they may want. Eventually, disagreements over the role of the state in society contributed to two factions of liberals (i.e. right and left) who saw enfranchisement quite differently. For right liberals, the right to vote should be a right afforded to financially independent individuals, thus the goal of this faction was to build a bourgeois community. Alternatively, left liberals assumed that the well educated should be enfranchised, with the goal of building a national community. Ultimately, the left liberals (social liberals) won control over policymaking and implementation. Conrad Theodor van Deventer, in particular, believed that education, along with political and social 
emancipation of the colonized in Netherlands East Indies, should be the focus of the Dutch government:

[As] the population has grown faster than its resources, its food and cattle [it is time for the Netherlands to give a helping hand to the natives with a new liberal policy of] benevolent individualism.

(Shmutzer 1977)

Social liberals and national liberals shaped the policies of the last half of the $19^{\text {th }}$ century (de Beus 2006), including education policies. Left leaning classical liberals seemed to equate enfranchisement and citizenship with being well educated, making education a means of nation building.

In sum, the gradual shift towards more left leaning liberalism near the end of the $19^{\text {th }}$ century gave way to social policies that empowered individual citizens, social safety nets such as security and welfare to the poor, and the introduction of the modern human, social, and natural sciences to the planning and organization of public policy (de Beus 2006, 88). This included compulsory primary education as well. These shifts trickled into the Dutch's colonial policy, which was formalized for the first time during this period.

I now turn to a discussion of the evolution of colonial education policies in The Netherlands East Indies, which evolved from a largely agriculturally based education prior to 1850 , to an increasingly more liberal, western-style education thereafter. 
Table 5.1: The Dutch Educational Framework in the Netherlands East Indies (pre-1850 to 1942)

\begin{tabular}{|l|l|}
\hline Time Period & Educational Framework \\
\hline Pre-1850 & $\begin{array}{l}\text { Agricultural Education Paradigm: } \\
\text { Emphasizes the development of agricultural } \\
\text { expertise, to increase the ability to exploit } \\
\text { resources. }\end{array}$ \\
\hline $\mathbf{1 8 5 0 - 1 9 4 2}$ & $\begin{array}{l}\text { Liberal Education Paradigm: } \\
\text { Emphasizes the development of critical } \\
\text { thinking skills, and the rights and role of free- } \\
\text { thinking citizens. }\end{array}$ \\
\hline
\end{tabular}

\subsection{Education as an Agricultural Enterprise (pre-1850)}

Prior to the shift in the Dutch ideological and economic interests noted above, education in the Netherlands East Indies was focused on developing agricultural prowess or was religiously based. These two forms of education were not conducive for developing the human capital critical for state building. Before the introduction of a liberal western education in the Indonesian archipelago, the pesantren ${ }^{34}$ was the main form of education for the vast majority of Muslim Indonesians, although it is unclear what the general literacy rate was. The Netherlands East Indies' earliest encounter with western education occurred in Portuguese-controlled areas, in which the Portuguese sent missionaries to provide natives with a Christian education. The first school for native elites was erected in 1536, but this was quickly retracted when the Dutch East India Company (VOC) arrived on the scene, for fear that education would stifle their control over the population (Penders 1968). ${ }^{35}$ By 1799, the total estimated number of native

\footnotetext{
${ }^{34}$ Howard Federspiel (2018) states that the pesantren stems from the $18^{\text {th }}$ century when learning centers for the Islamic faithful were established. These schools were privately run, with students entering the schools for a period of time and returning home when they felt that they had learned enough. Currently, they provide second-level training in Islamic subjects.

35 This fear was also mirrored by the British and French in Africa (White 1996).
} 
children enrolled in school was 5000 Christian pupils and access to school was limited to Christian converts.

The decision to take control over the provision of education was inspired by the Dutch's need to increase productivity in the archipelago. However, the type of education that the Dutch were willing to offer during the Cultuurstelsel period, under the tutelage of Johannes van den Bosch, only opened avenues to remedial education (Van der Eng 2004). By 1808, education became the mechanism for increasing cultivation, which meant maintaining the status quo- exploit and extract as much as possible. Therefore, during this time, the goal of education was not to mimic the shifts in educational policy occurring at home, nor to transmit western ideas. If the goal of the Dutch was to build a nation-state at that time, then the decision to implement agriculturally based education policies was inconsistent with this end; their motive was not to produce independent, free thinking citizens but subjects. Like their British and French counterparts the goal of education in the Netherlands East Indies prior to 1850 was to teach the skills necessary to increase productivity and crops for exploitation (Hutagaol 1986; Penders 1968; Van der Eng 2004).

This approach to education in The Netherlands East Indies is striking given that between 1500-1800 education was used as a tool for nation-building in Europe. Monarchs at the time used education as a means to cultivate nationalism and reinforce the legitimacy of their state (Scott 2006, 10). This nationalism was developed through education by ensuring that students were taught liberal ideals of citizenry, national identity, and loyalty to the crown. 
While the Netherlands East Indies did experience small gains in educational access to the general native population, access to education was still limited for nonChristian Indonesians. By 1846, 15,000 Javanese Christians were educated, up from 5,000 in 1799, an increase of 10,000 in 50 years (Penders 1968, 14). Although this was a significant gain, it was still a small fraction of the total population. Moreover, the content of the education was restricted to subjects that were not conducive to the civil society building projects occurring in Europe at the time. The deficit in the percentage of the population receiving an education and the populations relegation to only accessing agricultural education became further entrenched in 1849 , when a law was passed to prevent native Indonesians from entering European schools. This decision to exclude the native population from these European schools is significant, because the European schools provided instruction in subjects that could develop the skills needed to enter the civil service, as well as liberal ideals deemed necessary to become free thinking citizens albeit in service to the state (Scott 1998, 110-111).

Even though this law was exclusionary, it did represent a shift in the Dutch's perspective on the proper channels into the colonial bureaucracy, because the law emphasized the necessity of education for entering the bureaucracy even for low skill clerical work. Prior to this period, the bureaucracy was stocked with native elites, like the priyayi in Java, in addition to aristocrats and trained bureaucrats sent from the Netherlands. The timing of this is also important and interesting, because the decision to implement the exclusionary education policy was made one year after the reforms to the Dutch constitution (1848), which institutionalized liberalism. Again, it is here that we first see education articulated as the avenue for building bureaucratic competence in the 
archipelago, even though it did not include much of the native population. As with other historical instances where one paradigmatic shift gives way to another, this law led to other revolutionary laws as the Netherlands and Netherlands East Indies entered the second half of the $19^{\text {th }}$ century.

\subsection{The Rise of Liberal Education and Access to the Bureaucracy (1850- 1900)}

In the second half of the $19^{\text {th }}$ century, as the Dutch parliament eased into more liberal forms of governance, education in the archipelago began to take a new form (Penders 1968, 14). This shift away from an agrarian view of education can be traced specifically to the Auditing Act of 1864 (Comptabiliteitswet 1864) under Fransen van de Putte. ${ }^{36}$ This new law finally required parliament to set aside a budget for each colony. The ability to explicitly allocate funds to The Netherlands East Indies had been made possible originally by the increase in production and fiscal intake from the colony under the Cultuurstelsel system. The Auditing Act demolished Cultuurstelsel and was extended further with the Agrarian Law (Agrarischewet) of 1870, which provided planters with secure land tenure while protecting the rights and interests of the indigenous population (Penders 1968, 19).

The government gradually came to reali[z]e that the Javanese nobility and the village headers on whose effective cooperation the success of the Cultuurstelsel depended so much did not generally have sufficient education behind them to carry out their tasks efficiently. After a great deal of deliberation between The

\footnotetext{
${ }^{36}$ Isaäc Dignus Fransen van de Putte was a Dutch politician and Minister of Colonial Affairs from 1863 to 1866 (Parlement \& Politiek accessed 8/11/2018).
} 
Hague and Batavia, a royal decree of 30 September 1848 empowered the Governor-General to budget annually a sum of 25,000 guilders to establish training schools for Javanese officials.

(Penders 1968, 14)

Increased liberalism in The Netherlands subsequently led to the extension of Dutch language training to upper class Indonesians, and ultimately permitted indigenous Indonesians to attend European primary schools regardless of class and religion in June of 1864. This increase in liberalism occurred just before the drastic shift that was the Dutch Ethical Policy, introduced by Queen Wilhemina. This policy suggested that the Dutch had a moral obligation to contribute to the development of the population in the Netherlands East Indies. It is important to mention that this shift amplified policy changes that took place in the decades prior to the Dutch Ethical Policy. Leading to this policy, the Dutch perceived that they needed to retain their skilled workforce at home, and in response this necessitated indigenous low-level clerical and technical labor within the administrative apparatus (Penders 1968, 20). Thus, the expansion of education coincided with van de Putte opening the civil service to the indigenous population (i.e. 20 slots were given to native Indonesians) through a competitive entrance exam.

In addition to the Liberal desire to 'civilise' the indigenous population another important motive behind the decision to re-open Dutch language schools for Indonesians was the growing need of the colonial economy for Dutch speaking lower clerical and technical personnel. This demand resulted from the spread of Western private enterprise and the subsequent need of the colonial government to expand its administrative apparatus...Fransen van de Putte, in 1864 took the 
momentous decision — which again broke completely with past policy — to open civil service positions to all population groups in the colony. Candidates were to be accepted into the civil service on the basis of competitive examination.

(Penders 1968, 21)

As the demands for more skilled labor increased, the Dutch began founding institutions of higher education, especially for medical and teacher's training. However, this early provision of higher education was inefficient, with a completion rate of only $34 \%$ in the late $19^{\text {th }}$ century (Penders 1968,24$)$. Table I below exhibits the completion rate at Teachers' Colleges towards the end of the $19^{\text {th }}$ century. Even though completion rates increased later in the $19^{\text {th }}$ century, the number of pupils declined significantly in the final years of the century. This could have been in response to the low quantity of teachers, such that the number of pupils was limited to decrease the student-teacher ratio and increase the percentage of graduates. Yet, Table 2 provides a window into the quality of educational practices in the archipelago before the turn of the 20th century. By 1900, even though the number of students enrolled at teachers' colleges decreased from 249 between 1873-1877 to 105 between 1898-1899, the completion rates jumped from just $19.6 \%$ to $76.1 \%$. This suggests that the quality of the education increased towards the end of the century. 
Table 5.2: Teachers' Colleges Completion Rates in late $19^{\text {th }}$ Century (Penders 1968, 29)

\begin{tabular}{|c|c|c|c|}
\hline Year & \# of Pupils & Completion \% & \# of Grads \\
\hline $1873-1877$ & 249 & $19.6 \%$ & 49 \\
\hline $1878-1882$ & 655 & $34.8 \%$ & 228 \\
\hline $1883-1887$ & 590 & $26.4 \%$ & 156 \\
\hline $1888-1892$ & 393 & $55.5 \%$ & 176 \\
\hline $1893-1897$ & 364 & $48.4 \%$ & 80 \\
\hline $1898-1899$ & 105 & $76.1 \%$ & 218 \\
\hline
\end{tabular}

Source: Hartgerink, H.J.H. "De Staten-Generaal en het Volksonderwijs in Nederlands-Indie Op. Cit., 44. 1848-1918."

\subsection{The Expansion of Liberalism in the Archipelago (1900-1942)}

Moving into the $20^{\text {th }}$ century, the Dutch continued their trajectory towards greater colonial inclusivity, which was fully inaugurated with the Dutch Ethical Policy. The Ethical Policy expanded Dutch control over the archipelago and subsequently led to the extension of education to a larger swath of the indigenous population. During this time, segments of the population were trained in European schools both in the archipelago and in the Netherlands. The education provided at the beginning of the $20^{\text {th }}$ century reflected more of the educational tendencies of the Netherlands and the rest of Europe, as school began to teach more humanistic subjects in addition to technical skills. This marked a shift to quasi-liberal education, in which the goal was to build state bureaucracies (Hammerstein 1996, 114-116), and this is one of the early signs of state building. This was the natural outcome of the colonial government's need for more bureaucrats and not having enough European settlers to fill all the administrative roles. This shift became 
important later when the curriculum taught and the stated objective of filling bureaucracies was in direct conflict with the fact that not all natives educated in European schools were guaranteed a job in the bureaucracy, nor were they afforded the idealized rights purported in their formal training.

The Dutch utilized their ability to administer larger segments of the population to increase taxation on the indigenous population. This increased taxation occurred despite the fact that the well-being of the native population decreased as the population boomed (Penders 1968, 34). For instance, the population in Java and Madura was 4,499,250 in 1815 and approximately 28,386,121 in 1900 (Pelzer 1945). Interestingly, the influx of the population was the result of more vaccinations, the provision of safety nets for famines, and fewer violent interactions. Also, during this time the Dutch switched to the protectorate and steward model of colonialism. This meant lending money to the colony and creating new institutions to divide efforts to manage the various aspects of governance, in diverse locations. Yet still, the quality of life of the indigenous population suffered during this period, because the resources that were sent to the colony did not necessarily trickle down to the indigenous population.

The increase in taxation of the population did, however, have a critical and unintended consequence for state building. As the Dutch required more and more civil servants and the parliament continued to liberalize, they attempted to satiate the desire of the indigenous population to have more autonomy as taxation increased. The indigenous population became disgruntled with the fact that taxes continued to increase, while their ability to be involved in the governing process was limited to a select few. In response, in 1903 the Dutch passed the Decentralization Law that permitted more self-governance. 
This policy gave municipalities and regional councils greater autonomy from the Dutch controlled colonial government. This attempt to co-opt native intellectuals reached a pinnacle with the formation of the native administration corps (Inlands Bestuur). Prior to this native administration corps, natives were incorporated into the existing bureaucracy in piecemeal to meet the administrative needs and manpower deficits in the existing bureaucracy. The Inlands Bestuur differed from earlier native inclusion in the bureaucracy, because this new cadre of native bureaucrats were better trained, were given more responsibilities and better salaries than their predecessors. Likewise, they enjoyed formal recognition as an entity within the state, unlike in times past. Dutch observers in the Netherlands and East Indies rightfully predicted that the creation of the Inlands Bestuur was suggestive of an imminent independence movement or gradual transition to full autonomy.

Unfortunately, in 1906 inclusivity in the Netherlands East Indies regressed with the passing of the Village Act of 1906. On its face, this policy appeared to mean more liberalization, since it meant that villages would be recognized as legal entities. However, the true goal of this policy was to increase agricultural production, in line with van Deventer's philosophy of irrigation, emigration, and education (Pelzer 1945: 191). This meant that education would also take a step backwards in service to this end. In order to increase agricultural production in the periphery, the Dutch moved skilled Javanese to the outer islands between 1936-1940, while also increasing agriculture in Java and Sumatra between 1900-1940. Here, the Dutch's policies on education seemed to be a reversion back to the Cultuurstelsel period, in which education was used as a tool to maintain the agrarian status quo. This emigration policy was also an early iteration of the 
transmigration policies of post-independence Indonesia, which was characteristically a “colonization program" for the outer islands (Abdoellah 1987).

Even though liberal education seemed to be on the decline going into the middle of the $20^{\text {th }}$ century, during this same period there was an increase in Indonesian nationalism and demands for equality. The increasing Java-centric Indonesian nationalism and demands for equality were aided by Dutch Governor Idenburg, who viewed education as a means to create an autonomous native population (Penders 1968, 65). This redirect going into the middle of twentieth century contributed to the expansion of education and the strengthening of the Inlands Bestuur. By the time the Japanese military arrived in the archipelago, the Dutch education policy held that educational institutions were the "tool of westernization" and a means to build bureaucracies. In response to this dramatic change in education policy, there were some in the Dutch Parliament who were concerned that expanding access to education would make natives adverse to labor $(1968,74)$. These parliamentarians were correct in their assumption; however, they would not see this outcome that they dreaded until after the interruption of their settlement from 1942-1945.

\subsection{Japanese Interruption: A Critical Juncture (1942-1945)}

Up until the arrival of the Japanese army in the archipelago during World War II,

the Netherlands East Indies had experienced steady gains in the state and society building necessary for institutional transmission. In the early 1940s, the Japanese Empire desperate for oil to continue their war efforts during World War II (Sagan 1988), saw an opportunity to take advantage of the declining Dutch economy to create a stronghold in 
the archipelago. In order to sway the indigenous population to help them expel the Dutch from the archipelago, the Japanese military used their geographic commonality to garner support. Once they arrived in Indonesia in 1942, despite significant gains in access to education for a larger percentage of the colonial population during the Dutch colonial period, this was jeopardized when the Japanese military began an assault on the Dutch educational structures.

Their assault on education began with the articulation of a new education policy with the following goals: 1) make education more egalitarian; ${ }^{37}$ 2) systematically eliminate Dutch influence from the education sector; and 3) turn education institutions into an instrument of indoctrination (Hutagaol 1986). This translated into closing Dutchrun institutions of higher education (Thomas 1973; Junge 1973, 5). In addition to disrupting instruction at institutions of higher education, in general, formal education in the humanities came to a halt in response to the Japanese's new education policy. Moreover, changing the mode of instruction from Dutch to the Japanese language created significant issues, given that quick courses on Japanese language were insufficient for students to perform well. Along with these dramatic changes to education, the Japanese also changed the civil service. This included replacing the Dutch civil service with a Japanese equivalent (Kunkoku Gakulin), and co-opted Muslim leaders into complying with their occupation by permitting the founding of the Sekolah Tinggi Islam Benda (loosely translated as Islamic Institute of Higher Education).

The Japanese made several concessions to select groups, their education and bureaucratic policies had many limitations. First, similar to the Dutch, the Japanese

\footnotetext{
${ }^{37}$ The policy was articulated as egalitarian, but it was a far cry from guaranteeing equal access to quality education.
} 
concentrated education efforts on Java. Since all Dutch instructors were imprisoned or interned, many schools experienced teacher and faculty shortages. This was compounded by an insufficient amount of library materials, because all Dutch language books were thrown out. Most importantly, the Japanese military served as the primary representation from Japan during the occupation and was not equipped to provide education nor maintain the levels of education that had been in place upon their arrival.

Once the Japanese exited the archipelago in 1945, education came to a near standstill as the population focused on keeping the Dutch at bay upon their return. When the Dutch colonial officials regained control of parts of Java, revolutionaries who were also a part of the intelligentsia were forced to move to remote areas, forcing school closures. During this time, the Dutch controlled Jakarta, Bandung, Semarang, and Surabaya, while Indonesian educational elites moved to Yogyakarta. At the same time, much of the population was excluded from entering Dutch institutions of higher education, which comprised the majority of higher education institutions in central Indonesia. Thus, the limitations in space at indigenous institutions of higher education relegated the majority of the indigenous population to not receiving education beyond our high school equivalent.

\subsection{Post-Independence: Education and the Status of Weberian Institutions}

Even though Indonesia ultimately gained its independence from the Dutch officially in 1949 , the form that education took on the heels of the Japanese occupation was not the most favorable for successful state building. In fact, many of the gains made for greater access to quality education for a larger segment of the colonized population 
during the Dutch colonial period did, not fully recover. The paradigmatic shift to the goals of the educational process presented by the Japanese put Indonesia on a very different path, one leading to educational policies that dampened the maintenance of Weberian bureaucracies in Indonesia.

On its face, it would seem that education (and as a consequence, state building) flourished after independence. During the independence movement, Dutch-educated indigenous faculty, staff, and students contributed to the founding of several new institutions of higher education, including the prestigious Gadja Mada State University. Towards the end of 1949 when Indonesia formally was recognized as an independent state, classes resumed at the Sultan's Palace in Yogyakarta, while schools for medicine, dentistry, agriculture, veterinary medicine, law and technology were revamped or founded. The number of students at these higher education institutions increased from 500 students in 1949 to 1100 students and 70 academic staff in 1951 (Higher Education in Indonesia 1951, 135). Also, around this time, the Ministry of Education created a Political Science Academy with the expressed purpose of producing administrators (Thomas 1973, 63). These new institutions were modelled after the University of Indonesia, founded by the Dutch colonial government in Jakarta.

One of the major challenges to post-independence education and state building was the transition to Bahasa Indonesia as the language of instruction. At the time, Bahasa Indonesia was a newly constructed language from the Malay trading language and local languages by the nationalist independence movement leaders under the helm of Bung Sukarno. The unmeasured shift from Dutch and local languages as the language of instruction to Bahasa Indonesia created another disruption to the provision of education. 
This deficit was magnified by an influx of students seeking to gain an education at all levels, paired with the shortage in the number of academic staff. Thus, the gains from education expansion after independence were slow going, as the student-to-teacher ratio exploded at the expense of quality. This skimping in quality of education also had ramifications for bureaucratic institutions, as the skill level of those entering the civil service decreased in response.

The most significant divergence from the path set in the latter decades of Dutch colonialism in the archipelago was the new sense that education was a vehicle to power, since power and material wealth became very much tied to state institutions. Almost all the recognized independence leaders were well educated, receiving their education in both the archipelago and the Netherlands. This contributed to an association between education and the ability to achieve (Thomas 1965), and introduced a 1new route to power since the intelligentsia were received as legitimate leaders (Soemardjan 1962).

Second, this perception that education and entrance into state bureaucracies also meant access to power was aided by the loosening of conditions for entrance into higher education institutions, which led to an influx of indigenous students pursuing higher education. With the door to higher education institutions wide open, more of the indigenous population entered university in the hopes of landing a job in the state. However, the loose nature of university requirements produced an influx of degrees that were not always of the best caliber. Even still, right from the beginning of Indonesia's statehood, the tone had been set for how one accesses power in the archipelago: obtain an education, albeit subpar, in order to qualify for a bureaucratic position. The disconnect between the aforementioned poor quality of education in tandem with a recognition that 
education should be a qualifier for bureaucratic service would have, in some ways, disastrous consequences for the development of the state.

The consequences of increasing access to education without necessarily increasing quality would become even more entrenched in the middle of the $20^{\text {th }}$ century. As Indonesia entered the 1950s, higher education continued to develop during a time of instability, as concerns about staff shortages increased. In order to meet the demand for higher education, between 1950-1959 the number of state universities grew from 2 to 8 ; the number of institutions of higher education grew from 6 in 1950 to 45 in 1959. Total enrollment in state and private institutions grew from 6,158 in $1950 / 51$ to 32,501 in $1956-$ 7 (Development of Education in Indonesia 1956, 18). At the same time, enrollment in academies grew to 5,850 in 1959/60 (Hayden 1967, 497), as well as enrollment and attendance in elementary and secondary schools (i.e. from 4,926,370 to $8,220,465$ enrolled with a $60 \%$ attendance rate) (Statistic Division, Department of Basic Education and Culture 1956).

Even though the number of academic institutions in Indonesia swelled in the 1950s, shortages in teaching staff contributed to significant deficiencies in the quality of instruction given teacher-to-student ratios. In total, the number of teachers at all institutions of education were 2,908 , with approximately half of the staff being part time only. By 1956, in higher education there were 545 professors, 389 of which were Indonesian and 164 foreign born; there were 634 lecturers (i.e. 510 Indonesian and 124 foreign born); and there were 851 student assistants (i.e. 825 Indonesians and 26 foreigners) (Development of Education in Indonesia 1956, 17). This meant that of the entire population enrolled in educational institutions, both primary and secondary, there 
were approximately 4,938 teachers, professors, lecturers, and student assistants servicing $8,258,816$ students - a ratio of 1:1,672. Again, half of these instructors at various levels were part time.

As an attempt to resolve the disparity, academics institutions collaborated with the Ministry of Education to fly professors around to universities as adjuncts, much like circuit judges in the United States in the 1800s. These "flying professors" were mostly foreigners. Another solution was to send Indonesians overseas to study in other countries. There were approximately 1,556 Indonesian students studying in 15 countries in 1958-59 (Hayden 1967, 529). The largest portion of students was studying in the United States (526), in the Netherlands (417), and Australia (282). The final notable solution was to employ recent graduates as sources of administrative and teaching staff, and the appointed students were predominantly from University of Indonesia and Gadja Mada University (Hutagaol 1986, 115). Yet still, these attempts were not sufficient to produce the number of skilled workers and bureaucrats necessary to fuel a state the size of the Indonesian archipelago.

Adding to the issues created by lack of access to quality education, was the politicization of education. In the early years after independence, the linkage between education and politics was cemented as education became a means of indoctrinating the population for nation-building. This was different from the use of education as statesociety building during the colonial period, because the government embedded itself into the selection of education officials and the curriculum. For example, presidents and deans of universities were also representatives of the central government, with professors appointed by the Ministry of Education and the President of Indonesia (Indonesia Higher 
Education Law of 1961, article 20, section 2-5). With this level of oversight, the course structure and materials were infiltrated by politics, with a large portion of education dominated by Pancasila (The Five Principles), ${ }^{38}$ which was implemented by Sukarno's administration.

Specifically, the Guided Democracy era (1959-1965) under President Sukarno's regime led to: 1) the establishment of the Department of Higher Education and Sciences; and 2) the issuance of a higher education law. The Higher Education Law of December 4, 1961 (no. 22) was highly political and shifted the control over professors, students and private institutions to the government, by making law have oversight on curricula and textbooks, especially in the social sciences. Also, a number of university presidents, professors, and teachers were dismissed or demoted for mostly political reasons (Feith 1963, 370-371). This was a part of The Three Missions of Higher Education (Tri Dharma Perguran Tinggi), which included quota restrictions on the number of Chinese enrollments in institutions of higher education.

At the end of the Guided Democracy period in 1965, there were 300 public institutions and the number of students increased from 109,000 in 1961 to 278,000 in 1965 (Hutagaol 1986). Quantitatively these numbers look good, especially when we compare them to the enrollments in $1950(6,158)$ and $1965(278,000)$. However, as insinuated throughout this discussion of the post-independence period, this uncontrolled growth created serious issues for the bureaucracy. Due to the insufficient number of educators and administrators, the academic standards were below international levels, and

\footnotetext{
38 See Prawiranegara (1984:77). Pancasila is the philosophical theory and policy adopted by Indonesia under the Sukarno administration. It was explicitly a tool of nation building that promoted the following: 1) belief in one God; 2) righteous and civilized humanity; 3) a unified Indonesia; 4) democracy led by representatives of the people; and 5) social justice for all Indonesians.
} 
there was an under and over-supply in certain academic areas $(1986,158)$. At first glance, it would seem that the deep connection between the government and education would strengthen civil society. Yet, the reality of this framework was that it took the focus off of the educational process that would produce the skills necessary for a meritocratic Weberian bureaucracy, and placed it on building nationalism.

This all came to a head in 1966, when academic life was disrupted by the anticommunist campaign that ousted many faculty and students $(1986,281)$. During the anticommunist campaign, the Department of Education was eliminated and the plight of education was put under the control of the Department of Education and Culture whose vision for education was to produce qualified graduates for national development programs. This aim continued into the 1970 s, wherein education was appropriated once again for the political agenda of the Suharto regime, rather than to create trained professionals to populate the bureaucracy.

Therefore, going into the second half of the $20^{\text {th }}$ century many of the gains made for the desired outcome-Weberian institutions-during the colonial period were undermined by slippages in educational quality and the over-politicization of education. All this occurred despite greater access to education for a larger segment of the population. This meant that state building efforts were stalled going into the $21^{\text {st }}$ century, and even though Indonesia democratized in 1999, it is still plagued by sub-par government effectiveness. ${ }^{39}$

\footnotetext{
${ }^{39}$ See footnote 3.
} 


\subsection{Summary}

In sum, the transformation of colonial inclusivity in Indonesia can be traced back to early shifts occurring in the Netherlands during the $19^{\text {th }}$ century, both economically and ideologically. These shifts in their economic interests and ideological leanings towards classical liberalism, paved the way for a change in their goals for the Indonesian archipelago. While the expansion of education to the indigenous population in Indonesia largely began as a project to increase agricultural productivity in the Netherlands East Indies under the Cultuurstelsel system, it gradually evolved to reflect some of the effects that liberalization had on education in The Netherlands.

This investigation of the evolution of colonial educational policies in the Netherlands East Indies provides three primary contributions to the literatures of interest here. The first contribution of this chapter is an exploration of the historical determinants of colonial education. This contribution is important, because as the literature currently suggests, colonial strategy varied across the colonies irrespective of colonial origin (Bloom and Sachs 1998; Engerman and Sokoloff 2000; Englebert 2000; Englehart 2005; Greene 1988; Kupperman 1995; Landes 1998; Sachs 2001). The Dutch colonial government's behavior in the Netherlands East Indies and South Africa was different than in any of their other colonial possessions (Rogozinski 1999). Here, I provided some insight into why by exploring the ideological and economic motivations of Dutch colonial strategy in the Netherlands East Indies.

The second contribution of this chapter is a more nuanced explanation of how institutional transmission occurs through the causal mechanism of colonial inclusivity. 
This mechanism includes not only the expansion of education in a colony, but also its quality. I predominantly examine Dutch policy adaptations regarding native education using a two-part typology of educational quality—agricultural and liberal. This typology is informed by the historical education literature, which provides a window into the transformation of education in the West and in former colonies (Golding 2018; Scott 2006; White 1996). This typology assumes that higher qualities of education, occur in more liberal educational paradigms. Note that the Dutch vacillated between the agricultural and the liberal educational framework until the early part of the twentieth century, when they settled into the liberal education paradigm.

The third contribution of this chapter demonstrates how education is used as a tool of colonial and post-colonial state building, because it helps develop a highly skilled society. As mentioned in chapter II, the cultivation of society through education aids the transmission of Weberian institutions to the colonized population. The role of education as a socializing mechanism of state building is supported by scholars like Scott (2006) who argued that education moved from technical training to a tool for nation building, although not extreme nationalism, by helping create national unity and legitimizing the state. This contribution is an important addition to the state building literature (Niemann 2007; Reinhard 1996; Thies 2005; Tilly, Evans, and Rueschemeyer 1985; Young 2004), and suggests that scholars should account for with the importance of educational institutions in the outcomes of various colonial projects.

If the story were to end there, then we would assume that Indonesia would develop the state capacity necessary for effective state building and maintenance that is seen in former colonies like Singapore and Mauritius. However, that is not the current 
status of state capacity in Indonesia. Returning back to the assessments of educational attainment and state capacity in Chapter IV, if we just examine government effectiveness in Indonesia in 2010 its score is subzero on a scale from $[-2.5,2.5]$. I argue that the interruption of the Japanese military towards the end of World War II sent Indonesia down a different path, in which education became a tool of political leaders for building the nation rather than building a capable state. Under Presidents Sukarno and Suharto, access to education expanded quantitatively, but not in ways conducive to developing a segment of the population with the skills necessary to build and maintain apolitical, technically competent Weberian bureaucratic institutions.

Throughout this project, I have emphasized the importance of education and higher educational attainment levels within a population for effective state building. Here, I have explored mechanisms that may explain why greater access to education may not always translate into a more skilled population, or into strong state capacity.

Prior to 1942, Indonesia provided evidence for when colonial inclusivity was more or less ideal, as the population experienced greater access to quality educational and higher educational attainment levels towards the end of the Dutch colonial government's tenure. However, it also demonstrates how different types of colonialism can lead to divergent outcomes, as was evident from Japanese occupation of the archipelago between 1942-1945. Due to this difference and the failure of post-independence leaders to reconstitute the Dutch system, Indonesia began a new path that continues to plague the role of education, or the lack thereof, in its state building efforts. 


\section{Chapter VI: CONCLUSION}

\subsection{Findings and Contributions}

This investigation of colonial legacy explores how colonial education policies as a tool of state building ultimately affected the effectiveness of post-colonial state building efforts. This shifts the conversation away from how colonial legacy matters for economic development to its relevance for contemporary state capacity. In the context of the colonial studies literature, investment in education for colonized populations serves as an intervening process in the relationship between European colonial settlement and state building. This study provides a nuanced explication of this relationship by arguing that, as colonial governments created greater access to both western, liberal education and posts within the colonial bureaucracy, the institutional transmission proposed by existing literature was more likely to occur. This institutional transmission was instrumental to the endurance of colonial institutions and the post-colonial state building that undergirds contemporary state capacity.

Therefore, post-colonial state building was more effective in contexts where there was greater colonial inclusivity. Even when a small percentages of the population were empowered and equipped to engage with Weberian institutions, post-colonial leaders were more capable of building stronger states than colonial counterparts wherein colonial inclusivity did not exist or was weaker. This intervening process along with others previously explored in the literature expands our understanding of the variation in contemporary state capacity in the post-colonial world. 
The underlying logic of the relationship between colonial inclusivity and contemporary state capacity is presented in great detail in Chapter II. There I argue that the processes underpinning this causal mechanism—colonial inclusivity—-the dynamism that exists between the conditions in the metropole and in the colony. First, colonial education policy was influenced by the rise of constitutional classical liberalism in Europe (i.e. the metropole) and shifting economic conditions in the metropole. Second, the selection of colonial education policy and how it was implemented was influenced by the conditions in the colonies and the metropole's perception of the population. Colonies where the metropole's interest and the push for more public services in the colony created ripe conditions for the investment in colonial education and granting the colonized access to the bureaucracy, were better positioned for the transmission of Weberian institutions and an overall upward trend in state building. These colonies are hypothesized to have better contemporary state capacity than their counterparts.

In the first empirical chapter, Chapter III, I explore the relationship between the level of European settlement and contemporary state capacity, a relationship that has thus far only been qualitatively assessed. This relationship functions as an important intervening process in the Acemoglu, Johnson, and Robinson (2001) study and others like it. I test this relationship by employing the level of European settlement measure commonly used in the literature as an primary explanatory variable, along with four indicators of state capacity—government effectiveness, bureaucratic quality, the political constraints index, and tax as a percentage of GDP — as the dependent variable. I find that the level of European settlement has a positive, and significant effect on all the indicators of state capacity in 2010. This provides some quantitative evidence for the first half of the 
Acemoglu, Johnson, and Robinson (2001) argument (e.g. that the level of European settlement has an indirect effect on economic development by influencing institutional quality), as well as an empirical starting point for teasing out the influence of colonial legacy on contemporary state capacity.

I take this further in the second empirical chapter, chapter IV, with an assessment of the relationship between colonial inclusivity operationalized as colonial educational attainment and three indicators of contemporary state capacity in 2010 - government effectiveness, bureaucratic quality, and tax as a percentage of GDP. I find that even when accounting for the classic proxy for colonial legacy—level of European settlement—and some of the alternative explanations in the literature, such as colonial identity (e.g. British or French colonialism), economic development, and pre-colonial structures, colonial educational attainment levels in 1900 are a good predictor of at least two of the indicators of state capacity (government effectiveness and bureaucratic quality). I also demonstrate that this finding holds when I utilize a new measure of educational attainment (Lee and Lee 2016).

In chapter V, I build upon these empirical findings with a historical assessment of the development of colonial inclusivity and its long-term implications for contemporary state capacity in the Netherlands East Indies. In the Netherlands East Indies, the rise of classical liberalism in the Dutch parliament, along with an economic imperative to expand colonial operations beyond Java and Sumatra despite a shortage of European settlers, led to the extension of western, liberal education to populations in Java and Sumatra. By the early decades of the $20^{\text {th }}$ century, compared to the middle of the $19^{\text {th }}$ century, a larger segment of the Javanese and Sumatran population had access to 
education and even held posts within the state. The increase in the number of skilled laborers aided Dutch colonial authorities in extending their operations to outer islands, by migrating educated Javanese and Sumatrans to outposts in order to administer colonial state policies. The inclusion of the colonized population in the colonial state during this period equipped post-colonial leaders with the skills to continue state building efforts, even though this was disrupted by some of the shifts to the educational system under the Japanese occupation (1942-1945).

In sum, this project aims to provide a more detailed explanation of how the process of institutional transmission occurred during the colonial period. I find evidence that investments in education during colonial rule furthers state-building efforts in meaningful ways. Moreover, this investment and empowerment of the colonized population reinforced state-building efforts in both the immediate and long term. Colonies where colonial education policies were implemented that led to higher levels of educational attainment levels enjoy higher levels of contemporary state capacity than their counterparts who had lower levels of educational attainment levels at the turn of the $20^{\text {th }}$ century. Moreover, even though the investment in education increased most dramatically in the early decades of the $20^{\text {th }}$ century, the robustness tests suggest that selection of observations of colonial educational attainment from 1900 is a good predictor of colonial educational attainment levels in the middle of the $20^{\text {th }}$ century. This suggests that the investment in education right before the World Wars is a good predictor for educational policy thereafter.

The main contribution of this project is a more detailed exploration of how colonialism matters for contemporary state capacity, by exploring underlying processes 
of colonial state building and how these institutions endured after independence. It sharpens our understanding of the determinants of state capacity, a seminal concept in comparative politics and international relations. I also further our understanding of colonial legacies through the empirical findings of Chapter III and IV, which demonstrate that not only does the level of European settlement matter for state building, that colonial practices and interactions with the colonized population also matter more for understanding colonial impacts on and contemporary governance. The empirical findings and case study of Chapter V suggest that colonial practice had more than superficial ramifications for former colonies.

\subsection{Future Research}

Several extensions that would reinforce and deepen this examination of colonial education policies and their importance for contemporary state capacity. These include the inclusion of additional case studies and within-case analysis. Also, an exploration of the international externalities that influenced colonial policy, would further contextualize the policies employed. Furthermore, an expansion of the empirical assessments to later years of the colonial period and present levels of state capacity would increase the strength of this explanation. There is evidence from the Netherlands East Indies and British Malaya that suggests that the greatest expansion in education occurred between 1910-1930. Thus, an analysis that contemplates educational attainment in 1925 and the most recent indicators of state capacity may provide a clearer picture of the relationship between colonial education policies and contemporary state capacity. 
Previous studies of colonial legacy have made a compelling case for causal mechanisms and processes using a comparative historical analysis. While Chapter V's examination of the development of colonial inclusivity in the Netherlands East Indies creates a baseline for understanding, comparing the development of colonial inclusivity there to British Malaya and the Philippines would provide greater leverage over alternative explanations and demonstrate how variance in colonial inclusivity contributes to variance in contemporary state capacity.

This investigation could also be furthered by more extensive within-case analysis focused on subnational variation. In Indonesia, the administration of colonial education policies was not even across the archipelago. Since independence, Indonesia has also experienced varying levels of state capacity across the archipelago, with more effectiveness in some regions compared to others. Within-case analysis could assess whether colonial inclusivity can explain subnational variation in contemporary state capacity. This would also permit deeper explanation of patterns in educational provision based on gender, ethnic group, and religious background, which could contribute to within-case variance as well.

Scholars like McCoy (2009) and Sagan (1988) suggest the utility of investigating the international dimensions of colonial education policy. Competition for colonial territory and conflicts between states had an impact on the colonies that European powers controlled, how borders between territories were created, and the economic capacity of European powers (Owolabi 2015; Rodney 1972). One could assume that these dynamics would have some effect on colonial policies. For example, the implementation of the Cultuurstelsel period in the Netherlands East Indies was a product of the Napoleonic 
Wars in Europe, and the Netherlands' subsequent attempt to recover from the economic devastation of that period, by increasing its exploitation of the East Indies. Future investigations could explore how investments in education were influenced by international factors.

Finally, the study of colonial education policy could benefit from being updated with an empirical assessment of colonial educational attainment levels just before the First World War and present levels of contemporary state capacity. Even though investment in education for colonized populations did increase considerably towards the end of the $20^{\text {th }}$ century. The most dramatic shifts occurred in the years just before and during the First World War. As a robustness check, this investigation could benefit from choosing different years to assess this trend. Finally, once statistics on state capacity for 2020 are available, it would be interesting to test whether these effects persist today.

\subsection{Caveats}

Before concluding this study, it is important to provide a few caveats. First, I anticipate pushback from post-colonial scholars who may take issue with the fact that I am situating this discussion squarely in the Eurocentric political economy and state building tradition. Also, I want to acknowledge the fact that the metrics of governance are rooted in western notions of "good governance". Part of my contribution is to alter this existing tradition, by exploring the overlooked process of the development of the colonized population, assessing the variance in how European policies mattered for human development in the colonies. Second, much existing research implicitly assumes that forward movement in the colonies was at the mercy of Europe; by contrast, I want to 
highlight the many contributions of the developing world to the developed. Even though Europe influenced the agency of populations in the developing world, these populations still have agency.

More on the first caveat, it is important to make clear that this exploration of how colonial inclusivity contributes to state and societal building is not a normative claim that colonialism was a good thing. It is an unfortunate truism that sometimes positive outcomes stem from horrid circumstances. Put a different way, sometimes good things happen in bad ways. The goal of this study is not to make normative claims about whether colonialism was "good", but rather to provide a critical and empirical test of how colonialism matters for contemporary issues of governance.

I readily admit that exploring the legacy of colonialism for state capacity is an exercise in exploring Eurocentric acceptable forms of government, despite the reality that colonialism disrupted forms of governance considered legitimate by the indigenous populations of colonized areas. Scholars like Fanon (1961) made note of the fact that colonizers rewrote precolonial history by characterizing the world prior to their arrival as riddled with "barbarism, degradation, and bestiality" to justify western civilization's supremacy. Thus, I acknowledge that being an educated or intellectual native during colonial times meant acting in accordance with the belief that the proper forms of governance are those established by the West. At the same time, I also recognize that many of these intellectuals were at the forefront of anti-colonial movements.

The second caveat pertains to the positive outcomes that come from European colonialism, which may seem ironic when one considers that the colonies were created by the metropole for the metropole (Rodney 1972). Rodney (1972) notes that development 
in Europe occurred, intentionally, at the expense of underdevelopment in Africa. Additionally, most of the colonies in the Caribbean, Africa, and Latin America contributed to the ability of Europe to focus on innovation and capitalistic endeavors, without seeing much reverse benefit. Engerman and Sokoloff (2000) call attention to the fact that massive inequalities and reliance on slave labor in the Caribbean and Latin America contributed to major divergence in these two regions' trajectories of economic development because of human capital inequalities. European exploitation of labor in these colonies stifled rather than advanced the development of human capital. However, where the colonized population was economically and socially empowered via education, colonized populations were able to take advantage of the new institutional contexts they inherited and were better equipped to continue state building efforts after independence.

This study aims to provide clarity for why colonialism has mattered in world politics, showing how it continues to affect postcolonial polities. Highlighting this area of colonial policy can positively inform our present policymaking, as we think about the present and future needs and claims of countries still grappling with the effects of their colonial legacy. 


\section{BIBLIOGRAPHY}

Abdoellah, Oekan Soekotjo. 1987. "10: Transmigration Policies in Indonesia:

Government Aims and Popular Response." Center for Migration Studies special issues, 5 (2): 180-196.

Acemoglu, Daron; Simon Johnson, and James A. Robinson. 2001. "The Colonial Origins of

Comparative Development: An empirical investigation." American Economic Review, 91(5): 1369-1401.

Acemoglu, Daron and James Robinson. 2012. "Why nations fail: The origins of power." Prosperity, and Poverty, 2.

Almond, Gabriel and Sidney Verba. 1963. The civic culture. Political Attitudes and Democracy in Five Nations.

Almond, Gabriel and Sidney Verba. 1980. The civic culture revisited. Verba-Boston:

Little, Brown and Company.

Bäck, Hanna and Axel Hadenius. 2008. "Democracy and state capacity: exploring a Jshaped relationship." Governance, 21(1): 1-24.

Banerjee, Abhjit and Iyer Lakshmi. 2005. "History, institutions, and economic performance: The legacy of colonial land tenure systems in India." American Economic Review, 95(4): 1190-1213.

Bobby Banerjee, Subhabrata, and Prasad Anshuman. 2008. "Introduction to the special issue on "Critical reflections on management and organizations: a postcolonial perspective”. Critical perspectives on international business, 4(2/3): 90-98.

Banks, Arthur S. and Kenneth A. Wilson. 2013. Cross-National Time-Series Data Archive.

edited by Databanks International. Jerusalem, Israel.

Bayart, Jean-François. 1993. Religion et modernité politique en Afrique noire: Dieu pour tous et chacun pour soi. Karthala.

Benavot, Aaron, and Phyllis Riddle. 1988. "The expansion of primary education, 18701940:

Trends and Issues." Sociology of Education: 191-210.

Besley, Timothy and Torsten Persson. 2010. "State capacity, conflict, and development." Econometrica, 78(1): 1-34.

Bhabha, Homi K. 2012. The location of culture. Routledge. 
Bloom, David E., Jeffrey D. Sachs, Jeffrey Paul Collier, and Christopher Udry. 1998. "Geography, demography, and economic growth in Africa." Brookings papers on economic activity, (2): 207-295.

Bockstette, Valerie and Louis Putterman. 2007. State Antiquity Index (Version 3).

Boone, Peter. 1994. The impact of foreign aid on savings and growth. London School of Economics and Political Science, Centre for Economic Performance.

Bratton, Michael, and Nicolas Van de Walle. 1994. "Neopatrimonial regimes and political transitions in Africa." World politics, 46 (4): 453-489.

Butler, Eamonn. 2015. Classical Liberalism-A Primer. London Publishing Partnership.

Busse, Matthias and Carsten, Heffeker. 2007. "Political risk, institutions and foreign direct investment." European Journal of Political Economy, 23(2): 397-415.

Callahan, Mary. 2009. “Myanmar's perpetual junta'.” New Left Review, 60: 27-63.

Careaga, Maite, and Barry Weingast. 2003. "Fiscal federalism, good governance, and economic growth in Mexico." In search of prosperity: analytical narratives on economic growth: $399-435$.

Campbell, John L. 1993. "The state and fiscal sociology." Annual Review of Sociology, 163-185.

Chatterjee, Partha. 1993. The nation and its fragments. Princeton: Princeton University Press.

Cheibub, José Antonio. 1998. "Political regimes and the extractive capacity of governments: Taxation in democracies and dictatorships." World Politics, 50 (3): 349376.

Chong, Alberto and Cesar Calderon. 2000. "Causality and feedback between institutional measures and economic growth." Economics \& Politics, 12(1): 69-81

Clapham, Christopher S. 1982. Private patronage and public power: Political clientelism in the modern state. Burns \& Oates.

Cobban, Alan B., 1992. "Reflections on the role of medieval universities in society." Intellectual life in the Middle Ages: 227-241.

Coleman, James S. 1988. "Social capital in the creation of human capital." American journal of sociology, 94: S95-S120.

Coppedge, Michael, John Gerring, Staffan I. Lindberg, Jan Teorell, David Altman, Michael Bernhard, Steven M. Fish, et al. 2015. "Varieties of Democracy: Codebook v4." Varieties of Democracy (V-Dem) Project. 
De Beus, Jos. 2006. "Resilient Liberalism in a small Western European State." van Schie, P.G.C. and Voermann, G. eds., 2006. The dividing line between success and failure: a comparison of Liberalism in the Netherlands and Germany in the 19th and 20th Centuries (13). LIT Verlag Münster.

DeRouen, Karl R. and David Sobek. 2004. "The dynamics of civil war duration and outcome." Journal of Peace Research, 41 (3): 303-320.

Diamond, Jared, and Colin Renfrew. 1997. "Guns, germs, and steel: the fates of human societies." Nature, 386 (6623): 339-339.

Doner, Richard F. 1992. "Limits of state strength: toward an institutionalist view of economic development." World Politics, 44 (3): 398-431.

Doner, Richard F., Bryan K. Ritchie, and Dan Slater. 2005. "Systemic vulnerability and the origins of developmental states: Northeast and Southeast Asia in comparative perspective." International Organization, 59 (2): 327-361.

Easterly, William and Ross Levine. 2003. "Tropics, germs, and crops: how endowments influence economic development." Journal of Monetary Economics, 50(1): 3-39.

Engerman, Stanley L and Kenneth L. Sokoloff. 2000. "Institutions, factor endowments, and paths of development in the new world." Journal of Economic perspectives, 14 (3): 217-232.

Englebert, Pierre. 2000a. "Solving the Mystery of the AFRICA Dummy." World development 28(10): 1821-1835.

Englebert, Pierre. 2000b. "Pre-colonial Institutions, Post-Colonial States, and Economic Development in Tropical Africa." Political Research Quarterly, 53(1): 7-36.

Englebert, Pierre. 2002. State legitimacy and development in Africa. Lynne Rienner Publishers.

Englehart, Neil A. 2005. "Is Regime Change Enough for Burma? The Problem of State Capacity." Asian Survey, 45(4): 622-644.

Englehart, Neil A. 2009. "State capacity, state failure, and human rights." Journal of Peace Research, 46(2): 163-180.

Evans, Peter and James E. Rauch. 1999. "Bureaucracy and growth: A cross-national analysis of the effects of 'Weberian' state structures on economic growth." American Sociological Review, 10(1): 748-765.

Fails, Matthew D. and Jonathan Krieckhaus. 2010. "Colonialism, Property Rights and the Modern World Income Distribution.” British Journal of Political Science, 40(3): 487508. 
Fanon, Frantz. 1961. “On national culture.” Postcolonialisms: An Anthology of Cultural Theory and Criticism: 198-219.

Fanon, Frantz, Jean-Paul Sartre, and Constance Farrington. 1963. The wretched of the earth. Vol. 36. New York: Grove Press.

Fauvelle-Aymar, Christine. 1999. "The political and tax capacity of government in developing countries." Kyklos, 52(3): 391-413.

Fearon, James D. 2005. "Primary commodity exports and civil war." Journal of Conflict Resolution, 49(4): 483-507.

Fearon, James D. and David D. Laitin. 2003. "Ethnicity, insurgency, and civil war." American Political Science Review, 97(1): 75-90.

Federspiel, Howard M. "Pesantren." In The Oxford Encyclopedia of the Islamic World. Oxford Islamic Studies Online, http://www.oxfordislamicstudies.com/article/opr/t236/e0632 (accessed Aug 11, 2018).

Feyrer, James and Bruce Sacerdote. 2009. "Colonialism and modern income: Islands as natural experiments." The Review of Economics and Statistics, 91(2): 245-262.

Frankema, Ewout. 2013. "Colonial education and post-colonial governance in the Congo and Indonesia." In Colonial Exploitation and Economic Development: 173-197. Routledge.

Fukuyama, Francis. 2004. State-building: governance and world order in the $21 \mathrm{st}$ century.

Cornell University Press.

Fukuyama, Francis. 2005. "' Stateness" First." Journal of democracy 16 (1): 84-88.

Fukuyama, Francis. 2011. The origins of political order: From prehuman times to the French Revolution. Farrar, Straus and Giroux.

Fukuyama, Francis. 2013. "What is governance?" Governance 26 (3): 347-368.

Furnivall, John S. 1943. Educational Progress in Southeast Asia. International secretariat, Institute of Pacific relations.

Furnivall, John Sydenham. 2014. Colonial policy and practice. Cambridge University Press.

Gallup, John Luke, Jeffrey D. Sachs, and Andrew D. Mellinger. 1999. "Geography and economic development." International regional science review 22(2): 179-232. 
Geddes, Barbara. 1994. Politician's dilemma: building state capacity in Latin America (25). University of California Press.

Gereffi, Gary, John Humphrey, and Timothy Sturgeon. 2005. "The governance of global value chains." Review of International Political Economy, 12 (1): 78-104.

Glaeser, Edward L., Rafael La Porta, Florencio Lopez-de-Silanes, and Andrei Shleifer. 2004. "Do institutions cause growth?" Journal of economic Growth 9 (3): 271-303.

Globerman, Steven and Daniel Shapiro. 2002. "Global foreign direct investment flows: The role of governance infrastructure." World development, 30(11): 1899-1919.

Go, Julian. 2004. “'Racism' and colonialism: Meanings of difference and ruling practices in America's Pacific empire." Qualitative Sociology, 27(1): 35-58.

Golding, David. 2018. "The Colonial and Neoliberal Roots of the Public-Private Education Debate in Sri Lanka.” Journal for Critical Education Policy Studies (JCEPS), 16(1).

Government Effectiveness, W.G. 2013. "Worldwide Governance Indicators." World Bank. Accessed, 29.

Green, Andy 1990. Education and State Formation: the rise of the education systems in England, France, and the USA. New York: St. Martin's Press.

Greene, Jack P. 1988. Pursuits of happiness: the social development of early modern British colonies and the formation of American culture. University of North Carolina Press.

Grindle, Merilee S. 1996. Challenging the State: crisis and innovation in Latin America and

Africa. Cambridge University Press.

Grzymala-Busse, Anna. 2011. "Time will tell? Temporality and the analysis of causal mechanisms and processes." Comparative Political Studies, 44(9): 1267-1297.

Guisan, Maria-Carmen. 2009. "Government effectiveness, education, economic development and well-being: Analysis of European countries in comparison with the United States and Canada, 2000-2007." Applied Econometrics and International Development, $9(1)$.

Gurr, Ted Robert and Will H. Moore. 1997. "Ethnopolitical rebellion: A cross-sectional analysis of the 1980s with risk assessments for the 1990s." American Journal of Political Science: $1079-1103$.

Hall, Robert E. and Charles I. Jones. 1999. "Why do some countries produce so much more output per worker than other countries?" Quarterly Journal of Economics, 114, (1): $83-116$. 
Hammerstein, Notker. 1996. "Relations with authority." In H. Ridder-Symoens (Ed.), A history of the university in Europe: Vol. 2. Universities in early modern Europe (15001800): 113-153. Cambridge, England: Cambridge University Press.

Hameiri, Shahar. 2009. "Capacity and its Fallacies: International State Building as State Transformation." Millennium-Journal of International Studies, 38(1): 55-81.

Hayden, Howard. 1967. "Higher Education and Development in South-East Asia. Volume I, Country Profiles."

Hegre, Håvard. 2001. "Toward a democratic civil peace? Democracy, political change, and civil war, 1816-1992." In American Political Science Association, 95 (1): 33-48. Cambridge University Press.

Hendrix, Cullen S. 2010. "Measuring State Capacity: Theoretical and empirical implications for the study of civil conflict." Journal of Peace Research, 47(3): 273-285.

Henderson, Errol A and J. David Singer. 2000. "Civil war in the post-colonial world, 1946-92." Journal of Peace Research, 37(3): 275-299.

Henisz, Witold J. 2000. "The institutional environment for economic growth." Economics \& Politics, 12(1): 1-31.

Henisz, Witold J. 2005. POLCON_2005 Codebook. Accessed 11/10/ 2016. http://mgmt. wharton.upenn.edu/?LinkServID=52885580-9E3C-26B29DB42DEA99925A47

Howell, Llewellyn D. 2011. International Country Risk Guide Methodology. East Syracuse, NY: PRS Group.

Huber, Peter J. and Elvezio M. Ronchetti. 1981. "Robust Statistics." Wiley. New York.

Hutagaol, Said. 1986. "The Development of Higher Education in Indonesia, 1920-1979." 1531-1531.

Kaufmann, Daniel, Aart Kraay, and Massimo Mastruzzi. 2011. "The Worldwide Governance Indicators: Methodology and Analytical Issues." Hague Journal on the Rule of Law, 3(2): 220-246.

Jackson, Robert H., and Carl G. Rosberg. 1982. "Why Africa's weak states persist: The empirical and the juridical in statehood." World politics, 35(1): 1-24.

Junge, Gerhard. 1973. "The universities of Indonesia: history and structure.” Bremen Economic Research Society. 
Kapoor, Mudit and Shamika Ravi. 2012. "Determinants of corruption: government effectiveness vs. cultural norms." The BE Journal of Economic Analysis \& Policy, 12(1).

Karnow, Stanley. 1989. In Our Image: America's Empire in the Philippines. Headlines Series 288. Foreign Policy Association, 729 Seventh Avenue, New York, NY 10019.

Knack, Steven and Philip Keefer. 1995. "Institutions and Economic Performance: CrossCountry Tests Using Alternative Measures." Economics and Politics 7(3): 207-27.

Knack, Stephen, and Philip Keefer. 1997. "Does social capital have an economic payoff? A cross-country investigation." The Quarterly journal of economics 112 (4): 1251-1288.

Knack, Stephen. 1999. Aid dependence and the quality of governance: a cross-country empirical analysis. The World Bank.

Knack, Stephen. 2002. "Social capital and the quality of government: Evidence from the states." American journal of political science: 772-785.

Kohli, Atul. 1994. "Where do high growth political economies come from? The Japanese lineage of Korea's “developmental state”." World Development, 22(9): 1269-1293.

Krugman, Paul R. 1997. Development, geography, and economic theory. Vol. 6. MIT pres.

Kupperman, Karen Ordahl, and Ordahl Karen Kupperman. 1995. Providence Island, 1630-1641: the other Puritan colony. Cambridge University Press.

Laking, Robert. 2010. "State performance and capacity in the Pacific." Asian Development Bank.

Lambsdorff, Johann Graf. 2003. "How corruption affects productivity.” Kyklos, 56(4): 457-474.

Landes, David S. 1998. "The wealth and poverty of nations: Why are some so rich and others so poor."

Lange, Matthew. 2003. "Embedding the colonial state: A comparative-historical analysis of state building and broad-based development in Mauritius." Social Science History, 27(3): 397-423.

Lange, Matthew, James Mahoney, and Matthias Vom Hau. 2006. "Colonialism and Development: A Comparative Analysis of Spanish and British Colonies1." American Journal of Sociology 111(5): 1412-1462.23.

Lange, Matthew. 2009. Lineages of despotism and development: British colonialism and state power. University of Chicago Press. 
La Porta, Rafael, Florencio Lopez-de-Silanes, Florencio, Andrei Shleifer, and Robert W. Vishny. 1998. "Law and Finance." Journal of Political Economy, 106(6): 1113-1155.

La Porta, Rafael, Florencio Lopez-de-Silanes, Andrei Shleifer, and Robert Vishny. 1999. "The quality of government." The Journal of Law, Economics, and Organization, 15(1): 222-279.

Lee, Jong-Wha and Hanol Lee. 2016, "Human Capital in the Long Run," Journal of Development Economics, 122: 147-169.

Lee, Soo-Young and Andrew B. Whitford. 2009. "Government effectiveness in comparative perspective." Journal of Comparative Policy Analysis, 11(2): 249-281.

Levi, Margaret. 1998. "A state of trust." Trust and Governance, 1: 77-101.

Li, Quan. 2009. "Democracy, autocracy, and expropriation of foreign direct investment." Comparative Political Studies.

Lindert, Peter H. 2004. Growing public: Volume 1, the story: Social spending and economic growth since the eighteenth century (Vol. 1). Cambridge University Press.

Lipset, Seymour Martin. 1959. "Some social requisites of democracy: Economic development and political legitimacy." American Political Science Review, 53(1): 69105.

Magalhães, Pedro C. 2014. "Government effectiveness and support for democracy." European Journal of Political Research, 53(1): 77-97.

Mahoney, James. 2010. Colonialism and postcolonial development: Spanish America in comparative perspective. Cambridge University Press.

Marshall, Monty G. and Keith Jaggers. 2009. Polity IV Project: Political Regime Characteristics and Transitions, 1800-2007.

Matsuzaki, Reo. 2019. Statebuilding by Imposition: Resistance and Control in Colonial Taiwan and the Philippines. Cornell University Press.

Mauro, Paolo, 1995, "Corruption and Growth," Quarterly Journal of Economics, 110: 681-712.

McCoy, Alfred W. 2009. Policing America's empire: The United States, the Philippines, and the rise of the surveillance state. Univ of Wisconsin Press.

McEvedy, Colin and Jones, Richard. 1975. Atlas of World Population History, 1975. Facts on file, New York. 
Médard, Jean-François. 1982. "The underdeveloped state in tropical Africa: Political clientelism or neo-patrimonialism." Private Patronage and Public Power: Political Clientelism in the Modern State. London: Frances Pinter. 162: 192.

Migdal, Joel Samuel. 1988. Strong Societies and Weak States: State-Society Relations and State Capabilities in the Third World. Princeton University Press.

Migdal, Joel S., Atul Kohli, and Vivienne Shue. 1994. State power and social forces: domination and transformation in the third world. Cambridge University Press; eds.

Migdal, Joel Samuel. 2009. "Researching the state." Comparative politics: Rationality, culture, and structure, 2: 162-192.

Mitchell, Brian R. 2003a International Historical Statistics: Africa, Asia, Oceania, 17502005. Basingstoke and New York: Palgrave Macmillian 4th edition.

Mitchell, Brian R. 2003b. International Historical Statistics: The Americas, 1750-2005. Basingstoke and New York: Palgrave Macmillian 4th edition.

Mitchell, Brian R. 2003c. International Historical Statistics: Europe, 1750-2005. Basingstoke and New York: Palgrave Macmillian 4th edition.

Neumayer, Eric, and Laura Spess. 2005. "Do bilateral investment treaties increase foreign direct investment to developing countries?." World Development, 33(10): 1567-1585.

Niemann, Michael. 2007. "War making and state making in Central Africa." Africa Today: 21-39.

North, Douglass C. 1991. "Institutions." Journal of economic perspectives, 5(1): 97-112.

Owolabi, Olukunle P. 2015. Literacy and Democracy Despite Slavery: Forced Settlement and Postcolonial Outcomes in the Developing World. Comparative Politics, 48(1): 43-78.

Owolabi, Olukunle P. 2019. Literacy and Democracy despite Slavery: Forced settlement, post-abolition reforms, and postcolonial development in the West Indies and SubSaharan Africa. Forthcoming book manuscript.

Parry, Jonathan. 2006. The politics of patriotism: English liberalism, national identity and Europe, 1830-1886. Cambridge University Press.

Penders, Christian Lambert Maria. 1968. "Colonial education policy and practice in Indonesia: 1900-1942."

Pelzer, Karl J. 1967. "Pioneer settlement in the Asiatic tropics. American Geographical Society; New York, 1945.I, Country Profiles."

Pierskalla, Jan, Alexander De Juan, and Max Montgomery. 2017. The Territorial Expansion of the Colonial State: Evidence from German East Africa 1890-1909. British Journal of Political Science: 1-27. 
Prawiranegara, Sjafruddin. 1984. "Pancasila as the sole foundation." Indonesia (38): 7483.

Przeworski, Adam, Michael E. Alvarez, Jose A. Cheibub, and Fernando Limongi. 2000. Democracy and development: political institutions and well-being in the world, 1950-1990 (3). Cambridge University Press.

Przeworski, Adam. 2004. "Institutions Matter?" Government and opposition, 39 (4): $527-$ 540.

Przeworski, Adam. 2009. "Is the science of comparative politics possible?." The Oxford Handbook of Comparative Politics (1): 147-171.

Putnam, Robert D., Robert Leonardi, and Raffaella Y. Nanetti. 1994. Making democracy work: Civic traditions in modern Italy. Princeton university press.

Rauch, James E and Peter B. Evans. 2000. "Bureaucratic structure and bureaucratic performance in less developed countries." Journal of Public Economics, 75(1): 49-71.

Readings, Bill. 1996. The university in ruins. Harvard University Press.

Reinhard, Wolfgang. 1996. ed. Power elites and state building. Oxford: Clarendon Press.

Rodney, Walter. 1972. How Europe Underdeveloped Africa. London: Bogle-L'ouverture Publications.

Rodrik, Dani, Arvind Subramanian, and Francesco Trebbi. 2004. "Institutions rule: the primacy of institutions over geography and integration in economic development." Journal of economic growth, 9(2): 131-165.

Rogozinski, Jan. 1999. A Brief History of the Caribbean: From the Arawak and the Carib to the Present. New York: Facts on File.

Sachs, Jeffrey D. “Tropical underdevelopment." 2001. National Bureau of Economic Research, w8119.

Said, Edward W. 1979. Orientalism. Vintage.

Sagan, Scott D. 1988. The origins of the pacific war. The Journal of Interdisciplinary History, 18(4): 893-922.

Sandbrook, Richard, and Judith Barker. 1985. The politics of Africa's economic stagnation. Cambridge University Press.

Sandbrook, Richard. 1986. "The state and economic stagnation in tropical Africa." World Development 14(3): 319-332.

Sartori, Giovanni. 1970. "Concept misformation in comparative politics". American Political Science Review, 64 (4): 1033-1053. 
Schwartzman, Simón. 1992. "Non-western societies and higher education." The encyclopedia of higher education, 2.

Scott, James C. 1998. Seeing like a state: How certain schemes to improve the human condition have failed. Yale University Press.

Scott, Peter. ed. 1998. "Massification, internationalization, and globalization." The globalization of higher education. Buckingham, UK: Society for Research into Higher Education \& Open University Press.

Scott, John C. 2006. The mission of the university: Medieval to postmodern transformations. The journal of higher education, 77(1):1-39.

Selaya, Pablo and Rainer Thiele. 2012. "The impact of aid on bureaucratic quality: does the mode of delivery matter?." Journal of International Development, 24(3): 379-386.

Serageldin, Ismail and June Taboroff, eds. 1994. Culture and Development in Africa. Environmentally Sustainable Development Proceedings Series, No. 1. Washington, D.C.: The International Bank for Reconstruction and Development/The World Bank: 568.

Skocpol, Theda, Peter Evans, and Dietrich Rueschemeyer. 1999. "Bringing the state back in." Cambridge.

Slater, Dan. 2005. Ordering power: contentious politics, state-building, and authoritarian durability in Southeast Asia. Emory University.

Slater, Dan and Daniel Ziblatt. 2013. "The enduring indispensability of the controlled comparison." Comparative Political Studies, 46(10): 1301-1327.

Soemardjan, Selo. 1962. "Land reform in Indonesia." Asian Survey: 23-30.

Sokoloff, Kenneth L. and Stanley L. Engerman. 2000. "Institutions, factor endowments, and paths of development in the new world." Journal of Economic Perspectives, 14(3): 217-232.

te Velde, Henk. 2008. The Organization of Liberty: Dutch Liberalism as a Case of the History of European Constitutional Liberalism. European Journal of political theory, 7(1): 65-79.

Thies, Cameron G. 2010. "Of rulers, rebels, and revenue: State capacity, civil war onset, and primary commodities." Journal of Peace Research, 47(3): 321-332.

Thomas, Robert Murray. 1973. "A chronicle of Indonesian higher education: the first half century, 1920-1970.” Chopmen Enterprises.

Tilly, Charles and Gabriel Ardant. The formation of national states in Western Europe. Vol. 8. Princeton University Press; 1975.

Tilly, Charles. 1985. "War making and state making as organized crime." Violence: A reader: $35-60$. 
Todorov, Tzvetan. 1986. “ 'Race', writing, and culture.” In H. L. Gates, Jr. (Ed.), "Race,” writing, and difference: 370-380. Chicago and London: University of Chicago Press.

Uslaner, Eric M., and Bo Rothstein. 2016. "The historical roots of corruption: State building, economic inequality, and mass education." Comparative Politics, 48 (2): 227248.

Van der Eng, Pierre. 2004. "Productivity and comparative advantage in rice agriculture in South-East Asia since 1870.” Asian Economic Journal, 18(4): 345-370.

Van der Eng, Pierre. 2004. "Cultivation System (Cultuurstelsel)." Southeast Asia: A Historical Encyclopedia, ABC-Clio, Santa Barbara.

Van de Walle, Steven. 2005, August. "Measuring bureaucratic quality in governance indicators." In 8th Public Management Research Conference, Los Angeles, United States.

Vreeland, James R. 2008. "Political institutions and human rights: Why dictatorships enter into the United Nations Convention Against Torture." International Organization, 62(1): 65-101.

Wamba-dia-Wamba, Ernest. 1996. "Pan Africanism, democracy, social movements and mass struggles." African Journal of Political Science/Revue Africaine de Science Politique 1(1): 9-20.

Wantchekon, Leonard, Klašnja, Marko and Natalija Novta. 2014. Education and human capital externalities: evidence from colonial Benin. The Quarterly Journal of Economics, 130(2): 703-757.

Weber, Max. 2013. From Max Weber: essays in sociology. Routledge.

White, Bob W. 1996. "Talk about School: education and the colonial project in French and British Africa (1860-1960)." Comparative Education, 32(1): 9-26.

Whitehead, Clive. 1981. Education in British Colonial Dependencies, 1919-39: a reappraisal. Comparative Education, 17(1): 71-80.

Widner, Jennifer, and Alexander Mundt. 1998. "Researching social capital in Africa." Africa, 68(1): 1-24.

Winters, Jeffrey A. 2011. Oligarchy. John Wiley \& Sons, Ltd.

Young, Crawford. 1994. The African colonial state in comparative perspective. Yale University Press.

Young, Crawford. 2004. "The end of the post-colonial state in Africa? Reflections on changing African political dynamics." African Affairs, 103(410): 23-49.

Young, Robert. 2004. White mythologies: Writing history and the West. Psychology Press. 
Xu, Guo. 2018. "The Costs of Patronage: Evidence from the British Empire." American Economic Review, 108(11): 3170-98. 


\section{VITA}

Tiffanesha Irene Williams was born in Omaha, Nebraska on May 3, 1990 to Reginald and Rosemary Williams. She attended Creighton University and received a Bachelor of Arts in Political Science, with minors in Philosophy, Asian Studies, and Music in May of 2012. Tiffanesha then earned her Master of Arts in Political Science with emphasis in Southeast Asian Studies from Northern Illinois University in May of

2014. She completed her Doctorate of Philosophy in Political Science, with emphasis in Comparative Politics and International Relations, at the University of Missouri in April 2019. Beginning in the fall of 2019, Tiffanesha will be a postdoctoral fellow for the Department of Government at American University in Washington, DC. 